\title{
Cor do lugar IDENTIDADE e Memória
}


Autorizo a reprodução e divulgação total ou parcial deste trabalho, por qualquer meio convencional ou eletrônico, para fins de estudo e pesquisa desde que citada a fonte.

\section{Catalogação na public ação \\ Senviço de Biblioteca e Doc umentação \\ Escola de Comunic açõese Artes da Universidade de São Paulo}

lizuka, Silvana Dudonis Vitorelo

Cor do lugar: Identida de e Memória /

Silvana Dudonis Vitorelo lizuka - São Paulo: S.D.V. lizuka, 2014.

185 p. : il.

Tese (Doutorado) - Programa de Pós-Graduação em Artes Visua is -

Escola de Comunicações e Artes / Universidade de São Paulo.

Orientador. Donato Ferrari

Bibliografia

1. Cor 2. Espaço urbano 3. Identidade e Memória 4. Narrativas Visuais 5. Percurso e fragmento

I. Ferrari, Donato II.Título 


\title{
COR DO UGAR IDENTIDADE E MEMÓRIA
}

\author{
Dissertação apresentada ao \\ Programa de Pós-Graduação \\ em Artes Plásticas, área de \\ concentração Poéticas Visuais, da \\ Escola de Comunic açõese Artes da \\ Universidade de São Paulo, como \\ exigência parcial para obtenção do \\ título de Doutor em Artes Visuais, sob \\ a orientação do Professor Doutor \\ Donato Ferrari.
}

Silvana Dudonis Vitorelo lizuka São Paulo, fevereiro de 2014 


\section{BANCA EXAMINADORA}

Professor Doutor / Instituição

Professor Doutor / Instituição

Professor Doutor / Instituição

Professor Doutor / Instituição

Professor Doutor / Instituição

São Paulo
Assinatura

Assinatura

Assinatura

Assinatura

Assinatura

de

de 2014. 

A ignorância é santa. A persistência é humana.

(dito popular) 
Aos meus pais, Orlando e J anina, meu carinho e reconhecimento.

Em memória: Agneska, Vitor e Etore. 


\section{AGRADECIMENTOS}

Ao suporte incondicional da família -

Hugo, Marson, Rafael e Raquel (que me acudiu quando mais precisava).

À generosidade dos amigos -

Donato, Zibel, Atílio, Mozart, Paloma.

Ao amor que motiva a vida. 
RESUMO

Este trabalho trata de atentar o Olhar para a cidade, especificamente em áreas de grande movimentação de transeuntes em São Paulo.

E perceber a Cor como participante dos muitos elementos que compõem a cidade e a caracterizam - como identidade de um lugar e como parte da memória das pessoas que a vivenciam.

Pelo registro de percursos através de ensaio fotográfico, e pelo registro de fragmentos através de recurso pictórico, verifica-se a expressividade da Cor.

PALAVRAS CHAVE

Cor; cidade; identidade; memória; fragmento; percurso 


\section{ABSTRACT}

This study deals with an attempt to look at the city, specifically São Paulo, and perceive color as a participant of the many elements that constitute and characterize it - as the identity of a place and part of the memory of those who experience the city.

This has been done in high-traffic areas of passersby, where the city is even more fragmented and receives the most experienced interference in their daily life, by proposing two ways to capture and record the color: by the route, recorded in a photo essay, and by the fragments, recorded in a pictorial way - linking people's memory to the colors of the places. In both cases, it appears that color expressiveness always depends on its functions and context; it is a matter of relationship between colors.

\section{KFYWORDS}




\section{SUMÁRIO}

\section{PARIE 1}

APRESENTAÇÃO

INTRODUÇÃO

RELATOS

A CIDADE - FLÂNEUR

35

O OLHAR - MEMÓRIA

\section{PARIE 2}

NARRATIVAS VISUAIS

- PERCURSOS

- identidade do lugar

- registros fotográficos

- impressões

- FRAGMENTOS

- memória

- registros pictográficos

- impressões

\section{PARIE 3}

REFLEXÕES

PROCEDIMENTOS

\section{PARIE 4}

ANEXOS 
PARIE 1 


\section{APRESENTAÇÃO}

Este trabalho trata de atentar o O lhar para a cidade, especificamente São Paulo, e perceber a Cor como participante dos muitos elementos que a compõem e a caracterizam - como identidade de um lugar e como parte da memória das pessoas que a vivenciam. 
Sempre em áreas de grande movimento de transeuntes, onde a cidade é ainda mais fragmentada e recebe as mais vividas interferências no seu cotidiano, propõem-se propostas de capturare registrara cor:

Pelo percurso, registrado em ensaio fotográfico - buscando elementos cromáticos de identidade de um lugar;

Pelo fragmento, registrado de maneira pictórica — relacionando a memória das pessoas às cores dos lugares.

Em ambos, verifica-se que a expressividade da Cor depende sempre das funções que desempenha e do contexto, ou seja, é uma questão de relacionamento entre as próprias cores do lugar.

Com isso, observa-se a possibilidade da qualificação dos espaços urbanos através da sensível aplicação cromática. 


\section{INTRODUÇÃO}

Um dia, há muito tempo, depareicom uma ima gem de O beijo (1907/8 - "DerKuss", em alemão), de Gustav Klimt, pintor simbolista de origem austríaca. Pensei sobre algumas discussões a respeito da obra que havíamos tido - alguns enfatizavam o seu significado e as intenções do artista, muitos, observavam a composição e a diversidade da forma. Eu me disse então: "Só consigo ver a luz e a cor". Vez ou outra pensava neste espanto, mas ninguém parecia compartilhá-lo, nem mesmo compreendê-lo. Como diria Barthes, "a vida é, assim, feita a golpes de pequenas solidões". 
KUMT, Gustav. O Beijo (Der Kuss), 1907/8. Fonte: www.itusozluk.com ago/ 2012

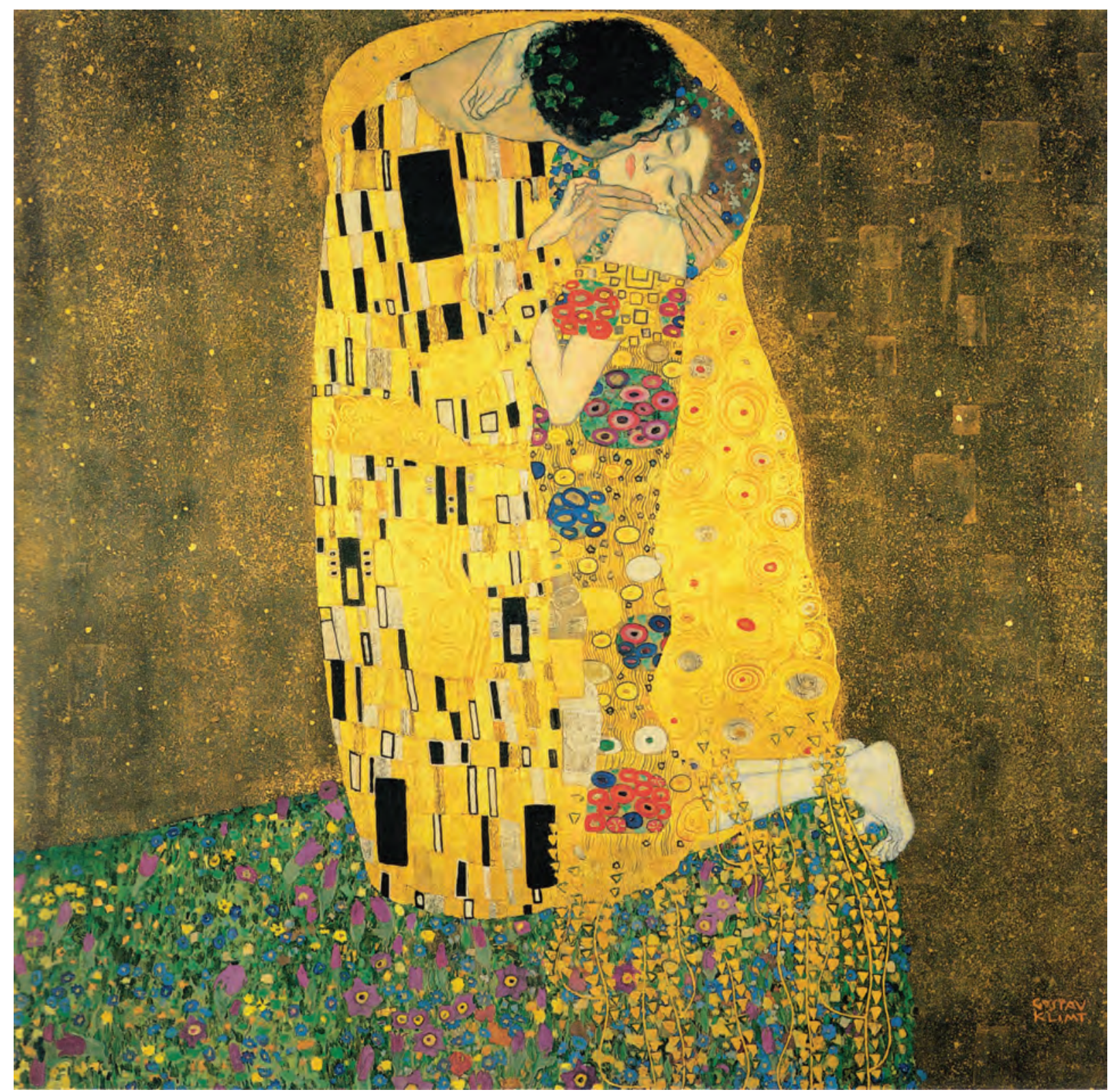


Meu interesse pela Cor adquiriu uma postura investigatória - voltada a colocar a cor como importante elemento de percepção, a ser observada como componente da qualidade dos espaços, e também utilizada como instrumento nessa qualificação.

Fic ou clara a necessidade de compreender o total desinteresse ou desconhecimento que o tema tem para muitos - sobretudo por arquitetos, alunos em formação e até mesmo artistas e designers que enfatizam a forma e optam pela neutralidade da cor. Em muitos momentos percebi o desprestígio pela percepção cromática frente à percepção formal - que mesmo em meio acadêmico, enfatiza-se a observação dos objetos e dos lugares para captar a síntese de sua composição formal, entre fechados e abertos, vazios e cheios... Porém, nada se diz sobre a luz que os envolve ou a cor que se enfatiza e os tornam particulares.

Há de certo muitos estudos sobre a cor — suas aplicações, suas técnicas, suas normatizações e até algumas indicações das formas adequadas às cores. Contudo, pensei se de fato é necessário dar forma à cor. Não seria ela uma sensação ainda mais complexa e autônoma que não estivesse atrelada necessariamente às questões formais?

Transcrevo a experiência de Israel Pedrosa (Da cor à cor inexistente), da percepção que muitos temos no cotidiano e não dos damosconta:

“Numa tarde de fevereiro de 1951, a o cair do dia, 'nessa hora em que as cores se tomam incomparavelmente brilhantes' por ação de contrastes entre as luzes que se atenuam e as sombras que se intensificam, minha atenção foi atraída pela beleza da relação de varias gamas de amarelo: um barranco cortado em desmonte para abertura de ruas num subúrbio do Rio, gramas queimadas pelo sol e arbustos calc inados. 
Exta sia do pelo efeito da hamonia dostonsque iam do a marelo puro à coloração da terra-desombra queimada, permaneci algum tempo a contemplara paisa gem. Uma mulher estendeu no varal três lençóis brancos, precisamente sob meu campo visual, a uns cinquenta metros de distancia.

Em dado momento, os lençóis e alguns papéis que se encontravam no chão pareceram-me banhados de um violeta intenso, sem que houvesse nenhum elemento dessa cor que pudesse influenciá-los, nem nas proximidades, nem na atmosfera, pois o azul do céu era límpido". (PEDROSA, 1982, p. 12)

A percepção de um momento ou de algo, se não uma qualidade inata, é possível através de um treinamento do olhar. Aprender a olhar é pessoal, depende do estímulo e da bagagem cultural e emocional de cada um. Acredito, porém que todos nós somos passíveis de aprendizagem - tal como acontece com a música, o desenho ou a dança. Se não nos tornamos experts podemos ao menos torna mo-nos a preciadorescapazes de distinguir, optar pelo ma is estético e ainda repeti-lo em outras situações. É uma capacidade humana que torna a vida mais repleta de significados e experiências.

Com algum esforço, cada qual encontrará o próprio caminho para entender, apreciar e aplicar a cor. $\bigcirc$ que se detém este trabalho é justamente relatar experiências de observação possíveis e retratação da cor nos espaços - que possam suscitar reflexão e janelas para possíveis e diversas formas de olhar. 


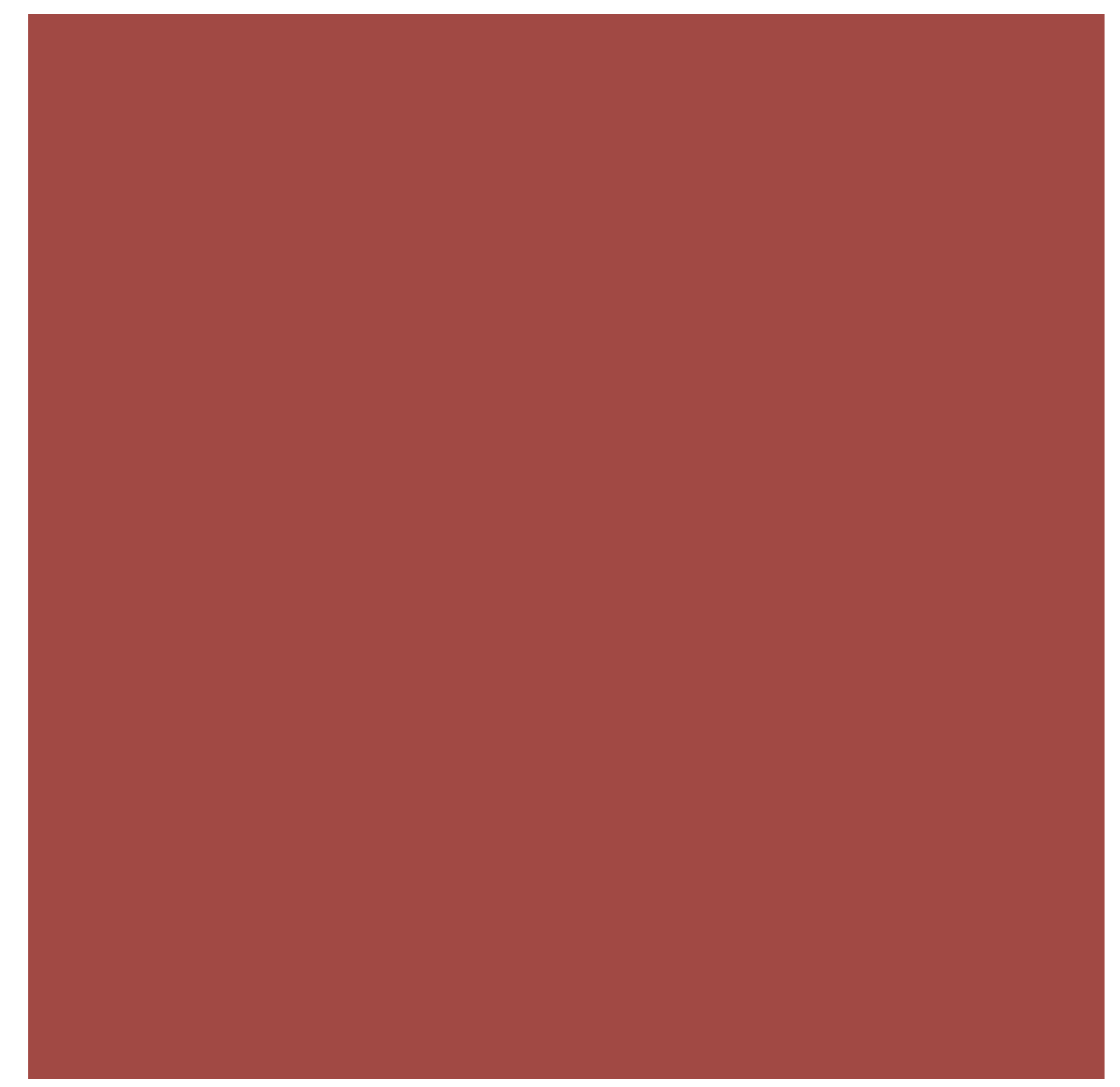




\section{REATOS REAÇÕES}

Era um vermelho intenso, profundo e vivo - tão intenso e reluzente que ainda posso vê-lo na memória, quase tocá-lo mentalmente. Como que o vermelho pudesse inundar-me, envolverme - daqueles vermelhos que tem ainda um toque macio e elegante.

Esta sensação permanece. Talvez a mesma sensação de encantamento que senti, aos três anos, ao ver o sofá vermelho que minha mãe comprara para a sala de estar. 
Foi tão intensa a sensação que não me contive, e com uma tesoura tirei um pequeno círculo do material, bem no meio do assento, onde seria mais fácil de uma mãozinha manusear a grande tesoura de costura.

Eu de castigo (disso não me lembro), e todos transtomados, não entendiam o porquê da qualidade da traquinagem. Eu não via assim, queria apenas guardar para mim parte daquela beleza de cor - isto é algo certo da intenção, pois tenho ainda a mesma sensação de estupor perante o mesmo vermelho.

Sempre pensei nesta história familiar, em contraponto ao completo desinteresse de alguns pela cor, na tentativa de entender as razões que me levam sempre a admirar as cores - em qualquer contexto, da obra de arte, da natureza, da cidade. O que me levam a percebê-la e a traçar ligação entre elas - em profundidades, valores, intensidades, proporções. Como se relacionam e se apresentam no espaço aberto, que está suscetível às alterações de luz natural.

Da mesma forma que passamos a desenhar livremente quando crianças - aparecem nas garatujas, o pai gordo e careca, a mãe de óculos e baixa, o cão torto e feioso -, somos completamente autênticos e verdadeiros ao olhar. Passamos, contudo, ao mundo das letras, que de fato não existem de forma material, mas são necessárias convencionalmente ao saber - deixamos de ver o fato e acreditamos no que não vemos, desenhando a forma de cada letra, que não parece ter significado, senão aquele forçado ao explicar o gênero das coisas: somente o a cursivo que assume carinha e tranças de menina, e o o cursivo, de menino de boné. 
Aospoucos somos doutrina dospara outros saberes, abrind o mão do sa ber intuitivo, e do olhar pessoal. Todos passam a desenhar a mesma casinha, de porta e janela, com chaminé e cerca - que não vemos, mas faz parte de um coletivo, de uma memória criada artificialmente que acreditamos existir. Vejo aí, quando nossa capacidade de ver, toma talvez o primeiro choque.

Para aquelesque precisam ou querem retomara capacidade de representaro mundo que se vê, pelos olhos físicos, é uma caminhada de retrocesso ao passado infantil. Desenhar passa a ser um exercício de não pensar o que acontece com aquilo que não se pode enxergar, mas colocarno papela linha que sobe ou desce numa perspectiva, ou a proporção daspartes de um todo, ou a distribuição no espaço da folha de um campo visual de interesse. Quem teve este incentivo desde criança se habilita com mais facilidade. É o ato de rabiscar e retratar a esmo enquanto se fala ao telefone, durante uma palestra entediante, sentado no ônibus torna-se um movimento espontâneo.

Algo semelhante que acontece com a aprendizagem da música ou da dança - em que se cantarola até afinar ou se dá rodopios no ar para tentar acertar o passo. Quanto antes melhor - mas a vontade pessoal em aprender é acima de tudo a maior alavanca ao êxito, pode-se sempre tornar-se um habilidoso. O ressentimento está em não contemplar a Cor no rol de aprendizados infantis, enfatizando sua existência no cotidiano - o que tornaria seu reconhecimento sensorial algo enriquecedor à percepção e ao entendimento estético.

Ainda sobre o desenho, Paul Valéry, em Degas Dança Desenho, relata a visão de Degas: "O desenho não é a forma, é a maneira de ver a forma". A expressão tem o sentido que se queira dar, da mesma maneira, que o olhar elenca o que se quer ver. Não se busca a representação fidedigna dos objetos através do desenho, mas seu entendimento representado. Por isto mesmo, a contrário de um desenho bem acabado, próximo ao objeto real, um croqui tem 
uma tensão latente de intenções que não representa tão somente o real, mas a síntese de uma ideia. "'O modo de ver' do qual falava Degas deve portanto ser entendido de forma a mpla e incluir. modo de ser, poder, saber, querer..." (VALÉRY, 2003, p. 160).

Pondera Valéry: "As coisas nos olham. O mundo visivel é um excitante perpétuo: tudo desperta ou alimenta o instinto de se apropriar da figura ou do modelado da coisa que o olhar constrói" (VALÉRY, 2003, p. 125). Este desejo de obter para si o objeto através de uma imagem, construída através da observação, ou reconstruída através da memória, acontece através do desenho, das tintas, das modelagens, das letras, dos sons, dos movimentos - meios de demonstrar uma percepção pessoal, conforme pode traduzir o olhar que se tem - levando sev executor a um estado inebriante e de arrebatamento "para a posse do que se quer ver...".

Minha avó matema, de origem lituana, contava uma anedota, como ela mesma dizia, do tempo de menina, em que ela aos seis anos, durante o período de guerras nos países bálticos, precisava levar mantimentos à irmã mais velha que morava na cidade. Ouvi tantas vezes que parece que está nos contando novamente:

"Colocaram-me no trem que saia a noite de Vilnas, onde duducas (vovô, em lituano) tinha

NOTA: Kaunas e Vilnas (Vilnius, em portugûes) eram asmaiores

cidadese, por

causa da guer-

ra, a lterna ram-se como capital do

país naquele pe-

ríodo de guerras

na região. uma fazenda de muitas terras e muitos filhos, com destino a Kaunas, em que Madalena morava

com o marido. Achavam que a capital seria um lugar mais evoluído mas no piso duro não cresciam beterrabas para o açucararou batatas para cozinhar... Era a viagem de uma noite inteira, onde com minha altura podia alcançarpela janela, via somente a noite muito negra, a névoa do vapor do trem - que da água quente se podia usar no samovar para o chá. Passava lá fora o vulto de postes, árvores e casas, dentro do vagão tudo parecia obscuro e suspeito. Levava como tesouro a quelas batatas que pareciam tão douradas quão preciosas, reluziam de ama relo intenso, ainda ma is intenso próximas a o roxo das beterrabas. Nos rostos sonolentos do trem, tudo parecia amedrontador, e embaçado, porque chorava pensando em voltarpara minha muchute (mamãe)". 
Cada vez que contava, parecia enfatizar ainda mais o amarelo reluzente das batatas no escuro da noite. Talvez por isto Klimt me pareça só cor com todo aquele dourado em suas obras. Com o conhecimento daquelas poucas cores, meus pensamentos passeavam em todo tipo de composição possível, variando o quanto de cada uma - ora as batatas, ora as beterrabas, ora a noite, ora a névoa.

Hoje, quando peço para alguém imaginar um círculo, o mínimo que me pedem é o tamanho que podem imaginar a figura. Quando peço para alguém imaginar o amarelo, nunca me perguntam a qualidade do amarelo, que há tantos... Fica-me sempre a dúvida se trata-se da falta de curiosidade ou de conhecimento da existência da gama de tonalidades.

Essa é uma questão bastante complexa para quem trabalha com a Imagem e, sobretudo, orienta e/ou ensina a sua leitura. Muitas vezes a visão é tão distante pelos próprios códigos visuais, de um ideário comum, que a representação da realidade já aparece distorcida - em que não se retrata o que se vê, mas o que se imagina, ou se julga conhecer. Como coloca JacquesAumont, “Em parte, a retórica da imagem continua porfazer” (AUMONT, 1995, p. 254).

Restringimos nossos conhecimentos sensoriais a nível muito elementar — onde não há riqueza de detalhes ou exercício intelectual reflexivo perante o que olhamos, simplesmente aceitamos e banalizamos - passando à imagem seguinte e assim por diante. Por vezes, o mundo torna-se ainda mais instável e transitório, onde nada há valor ov emoção.

A cor neste contexto de banalização do que se vê, passa a ser uma sutileza despercebida no grande rol de diversas informações sensoriais, como algo menor de atenção e, até mesmo, não identificada como valor pelo observador. 
David Batchelor, em seu livro Cromofobia, apresenta o status atual da cor, ou melhor, a falta dela sobretudo no caso aplicado das cidades. A cor é vista como uma queda pelo irracional, como um disfarce cosmético ou uma falta de sofisticação, uma contundente ambivalência cromática no ocidente. Descreve uma situação que ilustra bem a questão da cor na arquitetura em específico, numa tentativa - pela sua ausência —, de elitizá-la, de torná-la esteticamente exemplar. Tomo a liberdade de transcrever parte do capítulo 1 (Paisagens em branco. In: BATC HELOR, Cromofobia), pelo completo sentimento de vivenciamento que nos proporc iona e pelo tom narrativo do autor:

"Em algum momento do início da década de 1990, num mês de verão, fui convidado a uma festa. O anfitrião era um colecionador de arte anglo-americano, e a festa era na casa dele, situada ao sul de um país setentrional da Europa. Seguem-se as primeiras impressões que tive ao chegar. A casa era grande mas, já que todas ao redor também o eram, não parecia tão grande. A vizinhança - área opulenta de uma cidade rica - era o tipo de lugar onde apenas coisas pequenas ou chinfrins pareciam estranhas ou fora de lugar (como o bêbado solitário que vi, embrulha do num casa co velho a marelo-limão). Do la do de fora, a casa parecia relativamente comum: tijolos vermelhos, século XIX ou início do XX, ampla mas sem nenhuma ostenta ção. Do la do de dentro era diferente. Interiore exterior pa reciam não ter nenhuma relação. Em certo sentido, o interior da casa lembrava um avesso, maseu só perceberia isso muito ma is tarde. De início, pareceu-me interminável. Interminável quanto deve parecer um ovo visto de dentro; interminável porque inconsútil, contínuo, vazio, ininterrupto. Ou melhor: ininterrompível. Há uma diferença. Ininterrupto pode significar negligenciado, ignorado, inconspícuo, insignificante. O ininterrompível passa por nós, nos torna, a nós, inconspícuos, insignificantes.

O vazio ininterrompível e interminável dessa casa era impressionante - elegante e glamoroso de um jeito simples e discreto, mas também assertivo, enfático e ostentoso. Sentia-se ali um silêncio assertivo, uma ausência enfática, uma espécie de vazio ostentoso que só os muito ricos 
e extremamente sofisticados podem se permitir. Era um vazio estratégico, mas era também acusatório.

O interior dessa casa encerrava um mundo completo, um tipo de mundo muito particular, um universo despojado, claro e organiza do [...] um mundo que não admitia de pronto a existênc ia de outros mundos. Ou, se admitia fazia-o a contra gosto, com ressentimento, sem o menor traço de compaixão. Em particular, tratava-se de um mundo que nos fazia lembrar, aqui e ali, num átimo, tudo aquilo que não conseguimos fazer, tudo aquilo que provavelmente nunca nos daríamos ao trabalho de fazer, porque, de algum modo, tudo nos parecia fora de alcance, como quando olhamos pelo lado errado de um telescópio [...]

Há um tipo de branco que é mais que branco, e era esse o tipo de branco. Há um tipo de branco que repele o que the seja inferior, isto é, quase tudo. Era esse o tipo de branco. Há um tipo de branco que não é criado pelo alvejamento, masque é ele próprio o alvejamento. Era esse o tipo de branco. Esse branco era agressivamente branco. E se estendia sobre tudo ao seu redor, e nada escapava. Alguns poderiam responsabilizar o arquiteto, um homem que, dizia-se, definia seu trabalho como 'minimalista', que dizia ter como missão desnudar e purificar, a rquitetonic a mente falando, que os espaçospor ele criadoseram 'muito diretos' e 'muito claros', que neles não havia 'nenhuma possibilidade de mentira', porque 'eles eram apenas o que eram'. O arquiteto esta va dissimula ndo a verdade, claro, com essas mentira sinocentes [...]. Alguns poderiam responsabilizá-lo pela brancura acusatória desse grande interior vazio, mas suspeito justamente o contrário. Suspeito que poderíamos responsabilizar a brancura desse interior pelo tal a rquiteto e seu disc urso vazio" [...] (BATCHELOR, 2007, p. 11-13).

Batchelor descreve um interior branco que parecia vazio mesmo quando estava cheio - pois o que estava nele não pertencia ao lugar, tudo parecia deslocado, superficial, desnecessário - tanto os objetos quanto as pessoas. O que poderia se encaixar parecia estar adequadamente treinado para compor o próprio espaço. Tudo demasiadamente branco ou neutro, sem personalidade, sem identidade, sem lembrança, sem memória e sem emoção. Imaculado. 
Porém, tudo que parecia irrepreensivelmente correto e elegante, era desatrelado ao uso e às pessoas - o espaço nada refletia ou dizia de si ou de quem o habitasse; apesar de ainda ser capaz de ser reproduzido em outros espaços, em outras casas e, seria do mesmo modo, tomado pela mesma aura de elegância.

Em certa medida, nossos centros urbanos se apresentam assim, monocromáticos... Cinzentos... Onde as cores estão marginalizadas e nós, com medo de seus efeitos — num ato inconsciente de tornar os espaços momos, pasteurizados, desprovidos de experiências e incapazes de tornarem-se memória de alguém. Mas ainda assim, corretos e neutros a todos que o utilizam.

O monocromatismo acontece em boa parte das grandes cidades modemas, e me parece que com mais recorrência quando não há uma identidade/identificação com sua população, ou que apresenta parcela representativa de imigrantes e miscigenação. São Paulo apresenta esta realidade de várias culturas, em que pouco se vê da cor, prevalece o cinza do concreto, e na periferia o laranja dos blocos cerâmicos sem reboco (que quando rebocados, altera-se o status quo para o mesmo cinza dos centros). Somente olhando com muita atenção que encontramos resíduos da identidade de culturas que ainda se mantêm, como que em um gueto, em bairros distintos ou centros velhos; ou, ainda, em edifícios e lugares simbólicos que participam da memória das pessoas.

Sentido inverso desta tendência doscentros urba nos cinzase da branca arquitetura moderna, trilham a rquitetos ditos como coloristas, que enfatizam o uso da cor. Como é o caso dos arquitetos mexicanos Luis Ramiro Barragán (1902-1988), que considera a cor como sentido espiritual e místico, ou Ricardo Legorreta (1931-2011), que associa forma e cor. Ambos demonstram através de suas produções ser possível a cor imprimir identidade ao lugar e, em alguns momentos, a possibilidade da autonomia da cor, desvinculando-se a forma. 


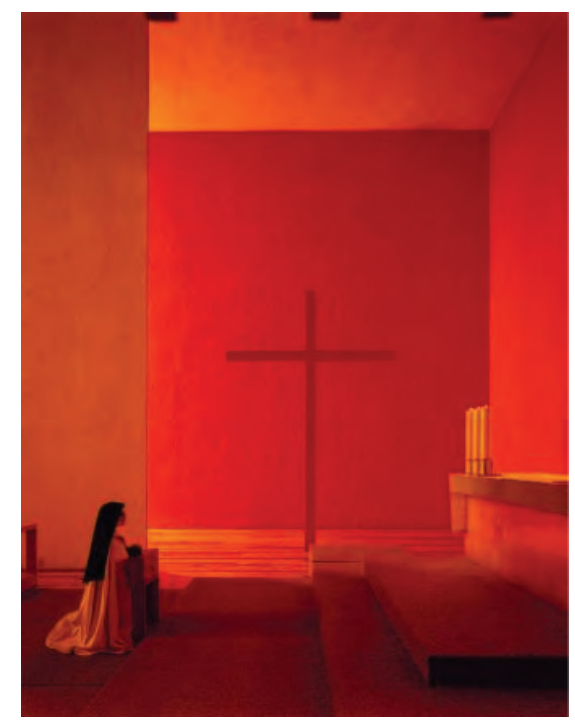

BARRAGAN.

Capela Tlalpan,

Sagrado Coração, Méxic o.

Fonte: www.floornature.eu

dez/ 2012

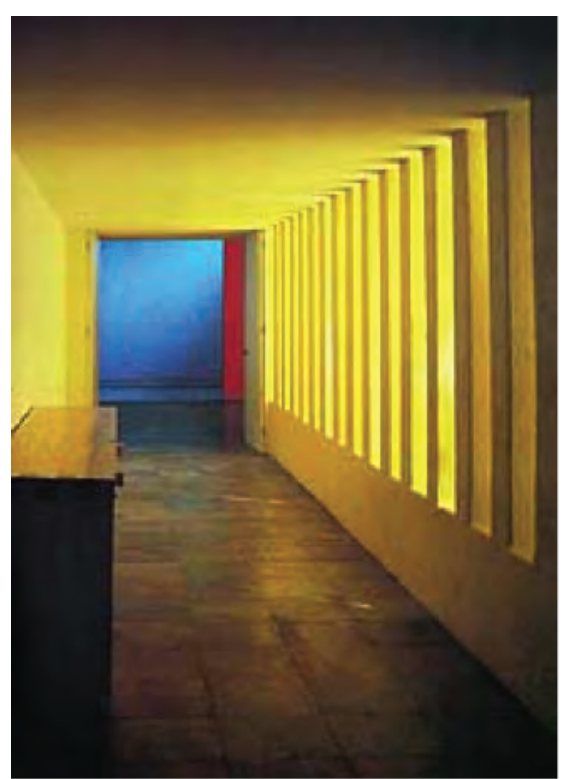

BARRAGAN.

Casa de Barragán,

Tác ubaya, México.

Fonte: www.arcspace.com

dez/ 2012 
NOTA: as indicações de imagense relatos da ótica do arquiteto Ricardo

Legoretta

foram obtidos em pesquisa

de entrevistas, copiladas na

public ação: Sonhos Cons-

truídos - entrevista s em São

Paulo.
No caso de Legorreta, o arquiteto explicita o uso das cores como que referenciais de suas lembranças e referências, e ainda, atreladas à identidade cultural do lugar.

Para Legorreta, a forma é enfatizada pela cor - muitas vezes em grandes planos contínuos. Vale-se da cor do entorno, da cor do céu em composições complementares e o reflexo da água para enfatizar, dar continuidade ao espaço pelo olhar, criar a miragem. As composições são fortes de cores saturadas que denotam força, clareza, identidade. Há a cor da terra e também do céu, que são típicas de cada lugar.

Mesmo a utiliza ção das coresanálogasou de mudança de nuances numa mesma paleta de cor, observa-se a intenção de intensificar a forma ou alterar o aspecto da profundidade - ora trazendo o fundo para mais próximo do observador, ora intensificando a distancia da profundidade. Cor e forma se harmonizam para compor o todo, porém cada qual tem seu peso e valor - não há relação de hierarquia entre elas, não há segundo plano ou a intenção do decorativo, do ornamental, da camuflagem. 


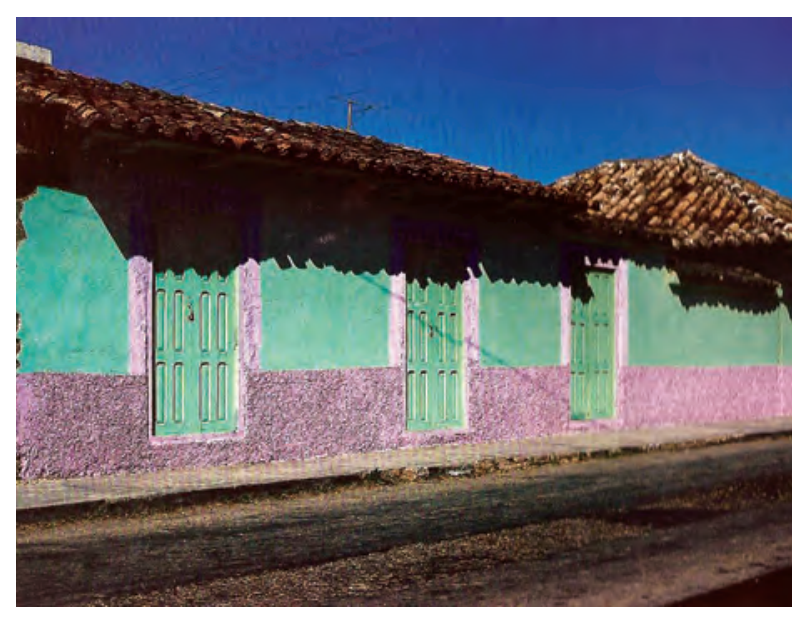

Chiapas, México.

Fonte: arquivo de Legoretta, in: Sonhos Construídos.

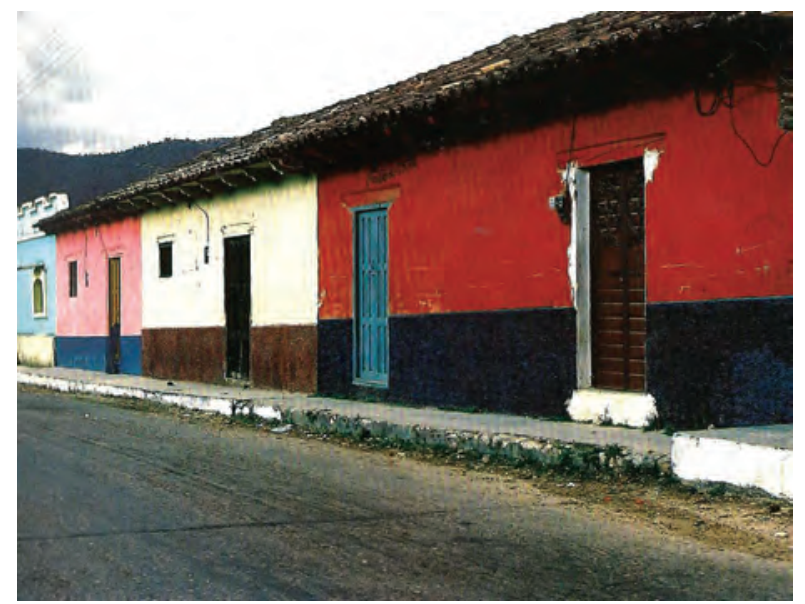

Chiapas, México.

Fonte: arquivo de Legoretta, in: Sonhos Construídos. 
Legorreta reafirma através de sua arquitetura a sua admiração pelos povoados mexicanos, onde as casas são muito coloridas conforme o gosto de seus moradores. O gosto popular privilegia as cores fortes, contrastes, sem preocupação com o "combinar", ou, antes, com uma preocupação intuitiva, livre, vinculada unicamente ao prazer dos olhos. Quando se interpelam os moradores dos Pueblos sobre as cores usas em suas casas, ouve-se: "Pintei assim porque gosto". Uma resposta simples e definitiva.

A aparente liberdade com o uso da cor não significa falta de rigor. A escolha da cor, como qualquer outra, tem sentido dentro de um universo de referências culturais - não se trata de uma produção mecânica, mas de significações pessoais e de um grupo que resultam numa arquitetura e num lugar com alma. Demonstra expressão e linguagem, vinculados com sua cultura de origem, adequadas ao tempo e ao lugar.

"Não é só por fazer um muro reto e pintá-lo de rosa que você é mexicano", explica Legorreta. Uma reprodução mecânica desses modelos resultaria em uma arquitetura sem alma, em um espaço sem identidade, uma mentira. Há várias outras influencias em seu trabalho, não somente a arquitetura tradicional mexicana.

Evidencia-se que a Memória e as experiências vivenciadas são a principal fonte de inspiração, onde os elementos de composição são meticulosamente estudados e aplicados de forma inovadora, revitalizada. Não se trata da simples cópia de elementos, mas de uma reorganização sutil e simbólica. 


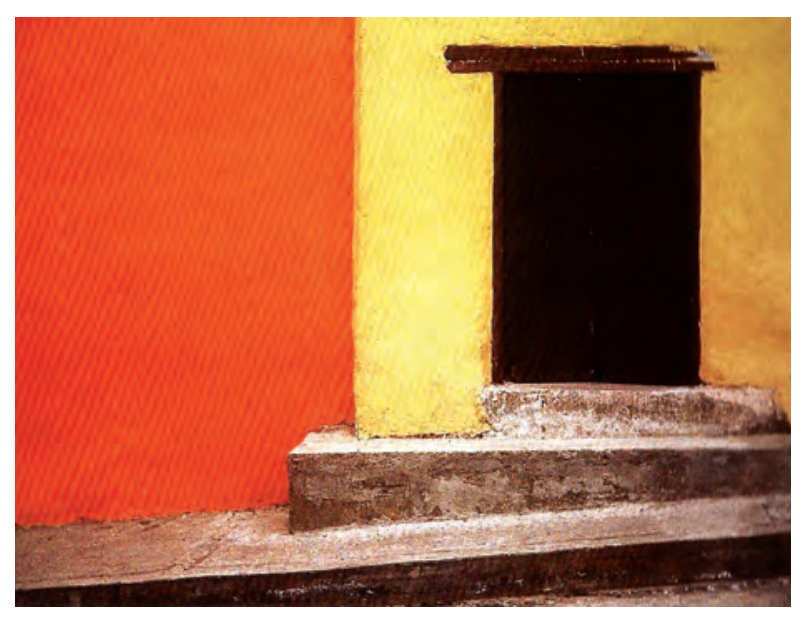

Hacienda, Puebla, México

Fonte: arquivo de Legoretta, in: Sonhos Construídos.

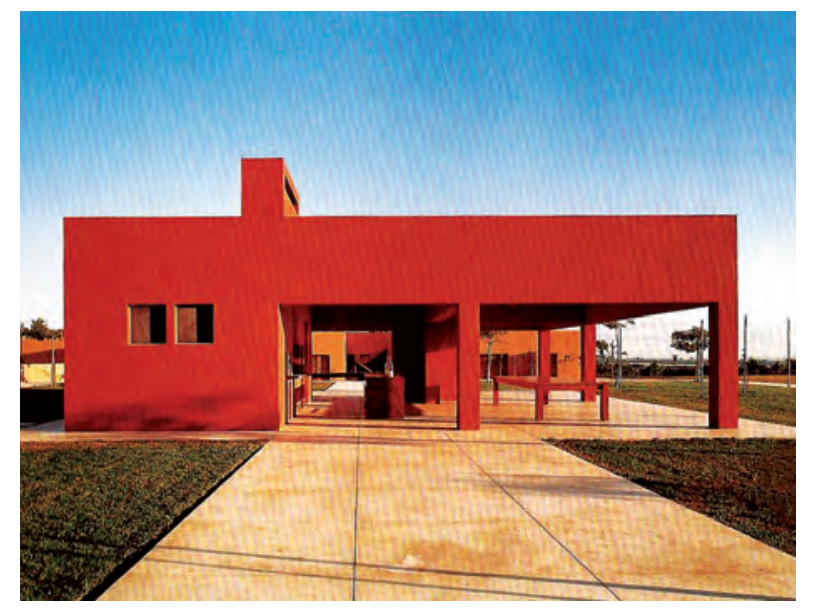

LEGORRETA,

Casa la Cruz, México. 2001.

Fonte: AKG/ Latin Stock 33 A

Casa Sotogrande 

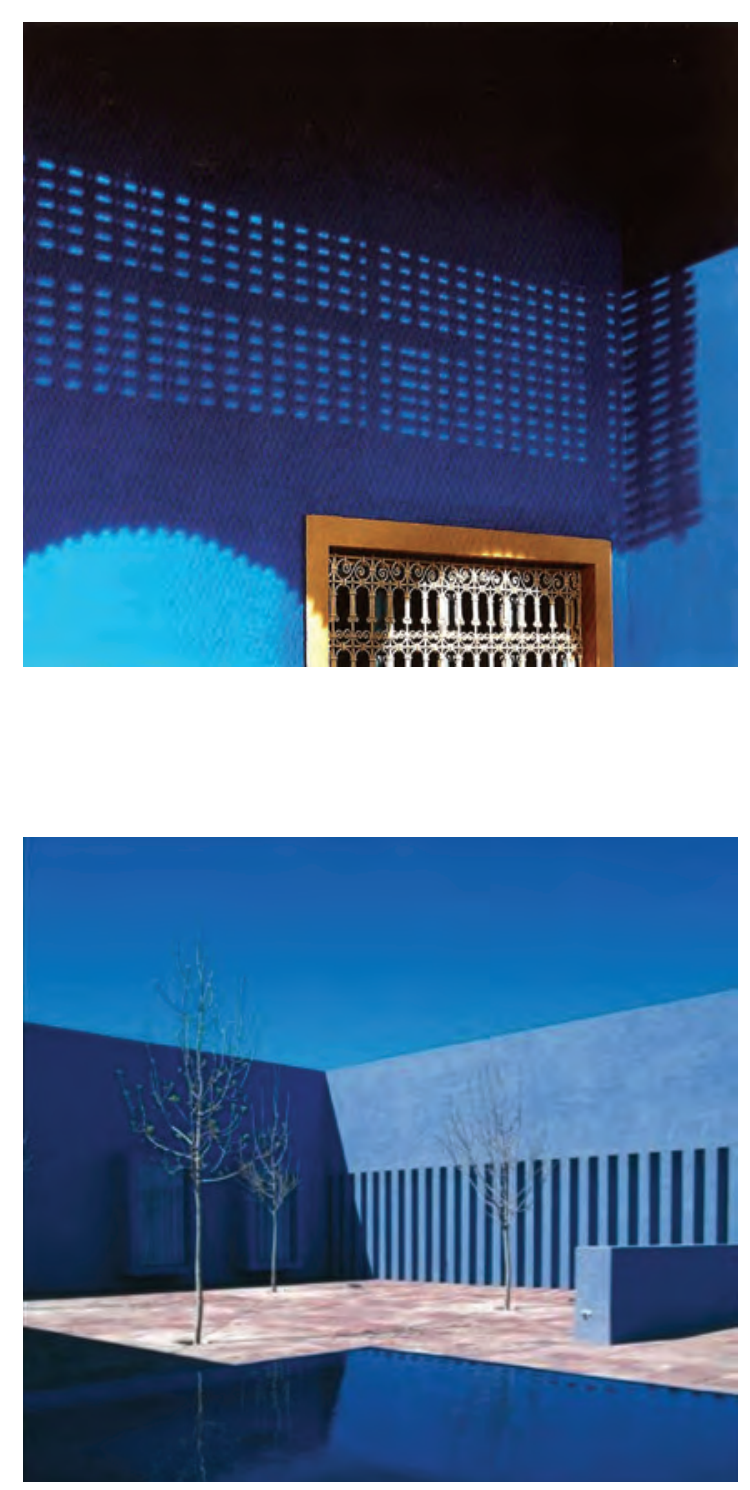

Marakesh, Marrocos.

Fonte: arquivo de Legoretta, in: Sonhos Construídos.

\section{LEGORRETA,}

Centro de Artes Visuais,

Santa Fé, EUA. 1999.

Fonte: www.legometalegorreta.com ago/ 2011 
Legorreta explica a importância da Luz na arquitetura e na influência da cor: formas, volumes e superfícies ganham diferentes sentidos segundo a maneira pela qual são utilizados e como incide a luz, possibilitando jogos de claro e escuro que alteram a percepção de um mesmo matiz de cor. Isto é bem observável na cidade, no sombreamento em que os edifícios se expõem.

Abertura spermitem enqua dra mentos, pontos de vista e a tenção, que a lia dos possibilitam que a luz seja graduada e marque sua entrada de forma diferente e inusitada, proporcionando uma nova dinâmica para o observador. Subverte-se assim a luz solar reverberada pela parede, transformando inclusive as cores que nela incidem.

O arquiteto conta de sua experiência infantil, de se sentir mal ou bem em determinados lugares, que o intrigava. A observação descompromissada constituiu o passo inicial de um caminho que se construiria ao longo do tempo: “Nesse processo de descobertas, as viagens representa ra m uma etapa importa nte, por enseja rem o confronto com o elemento estra ngeiro ou estranho, que convida o sujeito a redimensionar suas crenças pessoais. Mas a observação do entorno, do familiar e do pátrio é igualmente imprescindível". 


\section{A CIDADE RÂNEUR}

"As cidades, como os sonhos, são construídos por desejos e medos, ainda que o fio condutor de seu disc urso seja secreto, que as sua s regras seja m absurdas, as sua s perspectivas enganosas, e que todasascoisa sescondam uma outra coisa."

(CALVINO, 2002, p. 44) 
A cidade, lugar de encontros, reflexões e produções, é fascinante de ser contemplada. Promove inesperadas aventuras e desventuras - desperta memórias e provoca também sensações que frustram qualquer tentativa de descrevê-la e mais ainda em interpretá-la, pois depende menos do intelecto e mais do emocional para vivenciá-la. Há nela esconderijos ignorados, promessas de surpresase descobertas, encontros com tempos passadose ainda por vir, onde sua diversidade fragmentada convive e conflita.

As demolições de edifícios e de marcos da cidade retalharam a cidade, abriram espaço à passagem dos automóveis em ruas mais largas, ignorando o passado histórico. As funções dos centros se modificaram, saíram ora a fábrica, ora a moradia, mas mesmo assim são funções que ainda se escondem no emaranhado que é, entre outras ainda mais complexas. Por natureza, a cidade se reinventa - transgride e desintegra idealizações, perceptíveis através da observação do tempo e do espaço.

A cidade passa a exibir uma recomposição de antigos artefatos urbanos ou a transposição de marcos referencias de um contexto para outros ambientes construídos. Ou, como é o caso de alguns monumentos sem valor artístico ou referencial, que em ruinas sobreviventes da ação do tempo e da intervenção humana, denotam outro valor, o de resistência e continuidade de uma memória coletiva, em iminência de dissipação - passa a ser símbolo da passagem temporal, como contínuo movimento, como tempo perdido que se torna somente resgatável através da memória. 
A cidade moderna fragmentada é repleta de fragilidade de suas verdades e inconsistências, contudo nos desperta interesse pelas singularidades locais e contextos existentes. Não há verdades absolutas e idealizações que a resistam, admite infinitas interpretações, fragmentada em infinitas e imprevisíveis perspectivas. A cidade em processo requer a contaminação, de valores e desejos, com diversas intervenções e interferências, valorizando ainda mais os paradoxos do espaço urbano. "Os a tores da cidade exploram a turbulência dos espaços urba nos, a partir de um equilíbrio improvável entre a totalidade e os fragmentos, entre a homogeneidade e a heterogeneidade, entre o visível e o invisível, entre a memória e a sensação". (SCHULZ, 2008, p. 14)

O flâneur (do verbo francês flâner, significa passear para passar o tempo, vagar) como observadorda vida urbana, é um obsenvadorprivilegiado da vida moderna, como meio de apreensão e representação desse novo espaço. Walter Benjamin discorre em ensaios a atitude do poeta francês Charles Baudelaire, como figura do flanêur que se aprazia em observar refletidamente os moradores da cidade de Paris do século XIX, em suas atividades diárias.

A cidade e a multidão (bem descrita no conto $O$ homem da Multidão, de Edgar Allan Poe) passam a ser apreendida e registrada nas mudanças urbanas - não apenas do espaço, mas das relações pessoais e emocionais - , possibilitando novas formas de olhar o mundo e experimentar a percepção. Para Benjamin, os textos de Baudelaire constituem os fragmentos mais preciosos e intensos da vida social, revelando sutis articulações do indivíduo moderno com o cenário urbano e o respeito às vivências.

“Uma embriaguez acomete aquele que longamente vagou sem rumo pelas ruas. A cada passo, o andarganha uma potência crescente; sempre menor se toma a sedução das lojas, dos bistrôs, das mulheres sorridentes e sempre mais irresistível o magnetismo da próxima esquina, 
de uma massa de folhas distantes, de um nome de rua. Então vem a fome. Mas ele não quer saber das mil e uma maneiras de aplacá-la. Como um animal ascético, vagueia através de ba irros desc onhecidos até que, no ma is profundo esgotamento, afunda em seu quarto, que o recebe estranho e frio". (BENJAMIN, 2011, p. 186).

Baudelaire escreveu sobre as mudanças acontecidas - e que vinham e vêm acontecendo em continuidade - na sociedade, levando-o a questionar ideias estéticas tradicionais não adequadas ao dinamismo da nova sociedade e das necessidades das cidades modernas. $O$ flâneur vê o mundo em partic ular, sem pretensão de explicar, mas de mostrar o que vê, buscando sua identificação com a sociedade na qual convive, e percebe que é anulado como sujeito na multidão. Pela lógica do autor: caminhar, observar e imaginar.

Trata-se de um sujeito que toma posse visual de sua cidade e seus habitantes. Não há a intenção de explicar, mas nem por isto está livre de juízo, que é próprio do emocional mais do que da razão - como personificação de um olhar masculino (até então, vaguear à vontade pela cidade é essencialmente uma liberdade masculina), um olhar não-inocente da cultura em que cada época tem seu Olhar a ser decifrado.

A questão básica é que se trata de um narrador, desprovido de propósitos e por isto a berto ao que vê, ocupado em capturar a beleza do efêmero e do transitório, que emerge na experiência de sua condição de integrante da sociedade.

Oferece-nos, resultado da apreensão de uma profusão de imagens instantâneas do cotidiano, fonte para a reflexão, diante de um tempo resgatável através da memória e da consciência. A condição urbana exerceu um impacto sobre o indivíduo, modificando sua apreensão da realidade. A urbanidade moderna provocou a fragmentação e deterioração da experiência do mundo exterior, substituindo-o pelo interior. 
A proposta do registro dospercursos pela cidade de São Paulo está ponderada nesta a titude de vagar, observar e registrar - evidenciando o olhar voltado às questões da cor no espaço público em meio à multidão. É uma busca de entendimento do que pode ser resgatado como identidade e peculiaridade de um lugar, composto não somente pela cidade material, mas também pelo emocional de que a ocupa. 


\section{O OLHAR MEMÓRIA}

O filósofo francês Merleau-Ponty (1908-1961) no estudo da Fenomenologia da Percepção coloca que "a fim de ver o mundo, temos de romper com nossa aceitação a ele". Para romper a aceitação habitual é necessário readquirir o espanto, o assombro, ante as coisas da vida, para podervê-las em sua plenitude e provocar o pensa mento para retornara indagar, querer saber ou querer conhecer. 
Com efeito, a repetição monótona das coisas e dos fatos no dia-a-dia acaba nos impedindo de apreciar a totalidade da vida e, por isso, seria preciso rompercom a monótona visão, quase desdenhosa que damos às coisas - objetos, pessoas, fatos -, para redescobrir. O que bem o fez Baudelaire com seu flâneur - olhar com espanto as modificações da cidade e as relações pessoais, para depois produzir textos reflexivos, com uma carga emocional bastante concentrada.

Merleau-Ponty enfatiza que as pressuposições, os pré-conceitos e os pré-julgamentos do cotidiano atrapalham a nossa experiência mais profunda de olhar e tomar conhecimento das coisas, pois não se capta através dos sentidos e de uma experiência corporal. O mundo, a consciência (mente) e o corpo físico são partes de um único sistema e não devem ser avaliados em separado, que na verdade somos um "corpo vivido", que carrega em si as experiências que já viveu.

Consequentemente, valorizar o que nos parece ordinário, comum, sem importância. Modernamente, o excesso de informações visuais nos amortece, nada mais parece nos chocar ou fixar nosso olhar. Vivenciamos o momento dos fotógrafos compulsivos, que com toda sorte de aparatos registradores de imagens, as produzem no instante ínfimo de atenção, contudo que jamais serão revistas por seus autores ou compartilhadas com qualquer outro observador. $O$ que a fotografia nos prometev em registrar nossas memórias, nossas experiências, nossos entes querido, acabou por se diluir numa imensidão de arquivos sem fim. Cada vez menos percebemos o outro, e talvez também, nós mesmos. 
NOTA: Sartre a tribui ao Olhar

um lugarde

suma impor-

tância para a constituição do ser. Segundo ele, o olhar não está

ligado a uma forma determi-

nada, masa

uma manifes-

tação de tudo

que o lembre

(barulho de

passos, ranger de portas, etc).

O olharnão é neutro, ele me

avalia e me atri-

bui julgamentos

de valoresque

são, a o mesmo

tempo, verda-

deiros e falsos, e

porisso o outrem

me constitu

atra vés de seu

olhar.
A imagem é ausência e também presença. "A experiência da imagem, a nteriorà da palavra, vem enraizar-se no corpo. A imagem é afim à sensação visual. O ser vivo tem, a partir do olho, as formas do sol, do mar, do céu. O perfil, a dimensão, a cor [...]. O ato de ver apanha não só a aparência dascoisas, mas alguma relação entre nós e essa aparência: primeiro e fatal intervalo" (BOSI, 1977, p. 13).

O registro das nossas experiências visuais através da imagem — fotográfica, picłográfica, etc. - revela como a percepção, o olhar, é uma interpretação individual da realidade e não exatamente da realidade em si. A percepção é diferente para cada um, porque percebemos conforme o que nos importa, tomamos consciência de fatos, objetos e pessoas daquilo que nos chama atenção ou nos faz sentido, o que está intimamente ligado à vivencia/memória, à observação, à intuição pessoal, fazendo-nos organizar e interpretar os estímulos, atribuindo outros significados ao seu meio. A percepção é ambígua porque deixa transparecer a ambiguidade do mundo.

O olhar, como parte do processo de percepção, tem início com a atenção que não é mais do que um processo de observação seletiva, ou seja, das observações por nós efetuadas. Este processo faz com que nós percebamos alguns elementos em desfavor de outros, que podem ser agrupados em fatores externos, próprios do meio ambiente: como intensidade, contraste, movimento e a incongruência; e em fatores internos, próprios do individuo: como motivação, experiência anterior (hábito por aquilo que já entendemos) e a convenção social do grupo. A percepção dascores, dentro da percepção visual, compete com outras percepçõescomo a das formas, das relações espaciais, daintensidade luminosa, e dos movimentos. 
A modemidade tratou de tornar a a proximação da experiência do Olhar e da Memória intrigante, como incompatíveis - dado que o olhar está voltado ao imediato, sem interioridade, e a memória perece atrofiada, como uma função supérflua e estéril. É o que bem ser observa nos contextos urbanos, com a depreciação de qualquer edifício retrospectivo frente ao contemporâneo, numa ordem de mais-valia desigual e desatrelada à história do lugar, instaura-se um desequilíbrio na relação com o presente, presente vivido e representado como progresso.

A memónia é não somente olhar em direção a o passado, mas reconhecer as lembranças e enfrentá-las às imagens atuais - uma evocação com a inteligência do presente. A memória oferece o passado através de ver o passado, sem que seja possível dissociar recordador e coisa recordada, fazendo sentido entender a pessoa a partir do que recordou e também como a partir do modo que o fez recordar.

Observa-se que as lembranças são assentadas na afetividade, e na efetividade de acontecimentos de toda grandeza, assim como no impacto e eloquência que impuseram. A recordação traz consigo padrões e valores do observador, a marca de seus sentimentos que a afetividade proporciona a lembrança; e a marca da inteligência, a encontrar determinações. A capacidade da memória em focalizar coisas específicas, conectando-as ao conhecimento, nos traz novas ideias e novas interpretações possíveis para o cotidiano.

Traço um paralelo a Barthes, em A câmara clara - na tomada de decisão em pensar: "possibilidade de tomar o mesmo ponto de partida, analisar as imagens que existiam para mim, diminuindo uma espécie de desconforto quanto a darconta de todasaspossibilidades interpretativas possíveis. Seria uma maneira de eleger o que de fato nos chama a atenção e distinguir um senso comum e coletivo de um olhar ma is partic ular" (BARTHES, 1984, p. 18) - na tentativa de compreender as imagens e seu aproximação/apego a um elenco delas. Que, mais tarde nesse estudo pessoal, passo às narrativas visuais fragmentadas, que se voltam a participação da Cor em imagens selecionadas pelos critérios da memória e do olhar. 
NOTA: em sua obra, ele coloca certo "estalo", ou

um a tra tivo não identificável, que denomina "punc tum", o ponto do efeito, o detalhe

que é o acaso que, na imagem da fotografia punge ("mastambém me mortifica, me fere"), diferente de "studium" — "que designa uma espécie de interesse humano

- uma espécie

de investimento geral, ardoroso, é verdade, mas sem acuidade particular" (BARTHES, 1984, P. 45).
Barthes diz: "O referente adere".

Demonstra sua inquietação em relação ao referente, dizendo que só via o referente, o objeto desejado. Parece-me que o referente está quase sempre relacionado a um aspecto emocional, de apego, de simbólico, de memória; enqua nto que aquilo que não nos diz nada permanece como imagens inertes diante do olhar. Dizer que o homem está no mundo significa também enfatizar sua aderência às coisas, seu inevitável entrelaçamento com o que o cerca. 


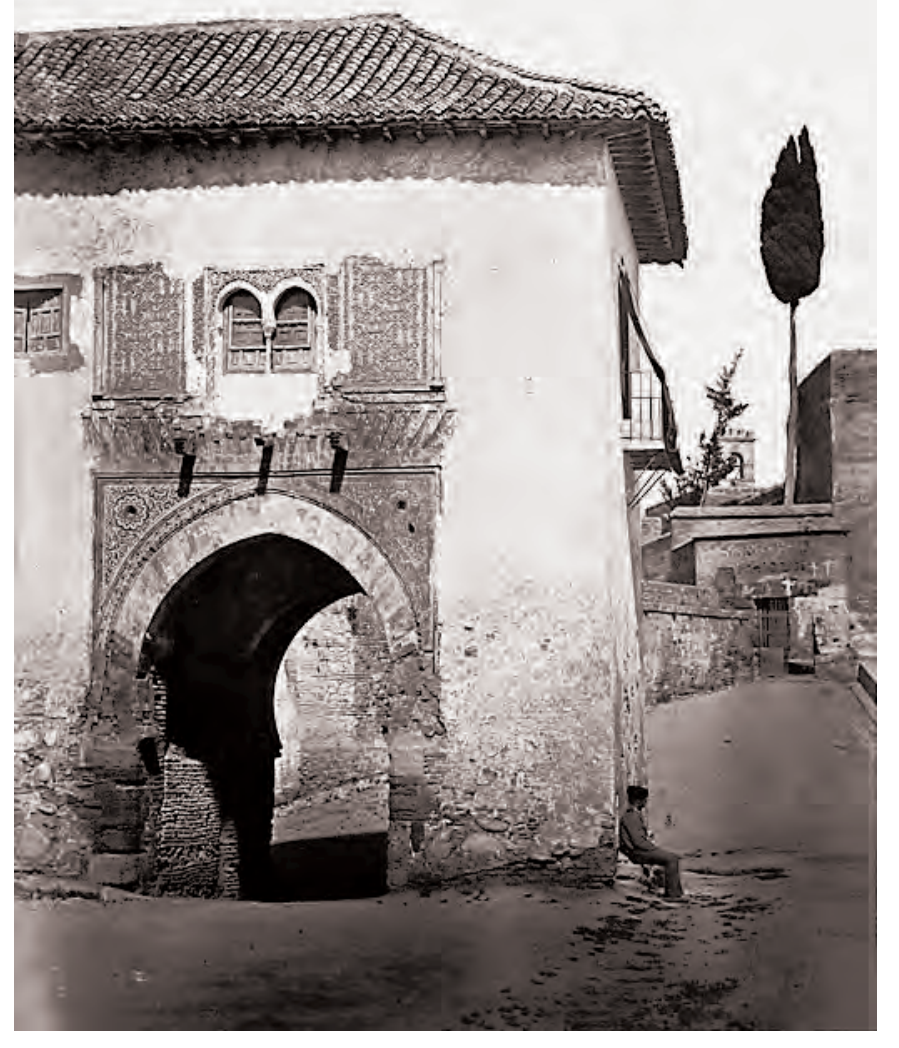

"É aí que eu gostaria

de viver...", Barthes.

Foto por CLIFFORD:

Alhambra (Granada),

1854 - 1856.

Fonte: BARTHES, 1984, p. 64. 
"Uma velha casa, um pórtico com sombra, telhas, uma ornamentação árabe envelhecida, um homem sentado de costas para a parede, uma rua deserta, uma árvore mediterrânea (Allambra, de Charles Clifford): essa foto antiga (1854) me toca: simplesmente porque tenho vontade de viver aí. Essa vontade mergulha em mim a uma profundidade e segundo raízes que não conheço: calor do clima? Mito mediterrâneo, apolinismo? Ausência de herdeiros? Aposentadoria? Anonimato? Nobreza? Não importa o que seja (de mim mesmo, de meus móveis, de meu fantasma), tenho vontade de viver lá, com finura - e essa finura jamais é satisfeita pela foto de turismo. Para mim, as fotografias de paisagens (urbanas ou campestres) devem ser habitáveis, e não visitáveis. Esse desejo de habitação, se o observo bem em mim mesmo, não é nem onírico (não sonho com um local extravagante) nem empírico (não procuro comprar uma casa segundo as vists de um prospecto de agencia imobiliária); ele é fantasmático, prende-se a uma espécie de vidência que parece levar-me adianta, para um tempo utópico, ou me reportar para trás, para não sei onde de mim mesmo: duplo movimento que Baudela ire cantou em 'Convite à viagem e vida anterior'. Diante dessas paisagens de predileção, tudo se passa como se eu estivesse certo de aí ter estado ou de aí dever ir. [...]" (BARTHES, 1984, p. 63-65).

Despertar para as imagens é um processo inquietante de lembranças conscientes e inconscientes, que selecionamos pelo desejo e pelo afeto. A distinção de olhar acontece quando algo particular, essencial a nós mesmos, nos chama. No caso da cidade fragmentada é ainda mais difícil perceber o que de fato relevamos com importância e aproximação. Pode-se considerar que a memória coletiva tem a tônica da importância para um grupo de pessoas, em determinado tempo e lugar, que coincidentemente as imagens selecionadas se fortalecem como referencia de um lugar, ou da lembrança de um lugar.

Quando se é andarilho em lugares desconhecidos tende-se a estar com um Olhar mais atento, tal qual viajante de outras culturas e línguas estranhas, a percepção se aguça e a leitura do 
espaço é o da descoberta. Andar por lugares comuns do cotidiano talvez exija mais da percepção, pois estamos propensos a identificar tudo como conhecido e destituído de graça e novidade.

Olhar é sempre um exercício de atenção, voltando a percepção aos vários níveis de consciência do espaço e do tempo. Nunca a mesma água passa sob a mesma ponte outra vez? - pois a cada investida, nós próprios somos outros, com outros olhares e sapiências... Mas não somos essencialmente os mesmos por carregarmos as mesmas memórias? 
PARIE 2 


\section{NARRATIVAS VISUAIS}

A decisão mais importante - a de como estruturar a apresentação da percepção da cor na cidade - , foi em adotar dois níveis distintos de recorte de percepção que os meios de registro destas imagens me interessavam.

Para ambos, a escolha do local sempre teve as mesmas primícias: que fossem áreas urbanas de muito movimento de transeuntes, com lugares de permanência e ta mbém de mera passagem, e que fossem de alguma forma, referenciais. As atividades nestas áreas também foram decisivas para elencá-las, onde a cor passa a ter uma importância maior na composição dessa paisagem - desde as barracas de ambulantes, aos estabelecimentos comerciais e às instituições.

Nos registros interessava-me observar o comportamento das composições e as escolhas cromáticas que estariam ora vinculados à identidade do lugar, ora à memória pela continuidade ou relevância aos usuários destes espaços. Assim, a denominação de Narrativas Visuais compreende dois momentos de obsenvare registrar: 
1. O registro através da fotografia, da cor nas imagens observadas - que é uma ação mais imediata na captação do lugar, optando pelo recurso do trajeto pelas ruas e o registro serial destas imagens que gradativamente se apresentam ao observador. Está ainda vinculada à ideia de flâneur, que vagueia, afasta e aproxima o olhar conforme o que lhe absorve a atenção.

O percurso permite visualizar um todo da paisagem e está muito indicado na percepção de uma identidade do lugar, pela repetição de alguns padrões específicos daquele lugar, como característica comunitária e social. Permite também uma alteração rápida do foco, elegendo o que nos seduz no trajeto. O resultado das imagens obtidas está sujeito à reflexão sobre a diversidade destas imagens, em que se pode selecionar, reorganizar e traçar um discurso congruente do que se deseja demonstrar.

2. O registro através da aquarela, na percepção das cores e suas relações no espaço. A construção deste registro pictográfico é lento e introspectivo, onde a retratação do lugar nunca se faz unicamente com a observação, mas refaz a imagem por parâmetros individuais do imaginário. Por isto, a construção do registro está muito mais voltada a observar partes, fragmentos da cidade, cuja escolha acontece por vezes através da subjetividade e de valores da memória, seja ela individual ou coletiva.

Ou seja, a aquarela exige o olhar mais atento, mais pontual e reflexivo, pois a própria técnica da aguada tem seu tempo de execução e sua exatidão no retra to, não permite retoques. Parte da construção desta retratação está voltada a perceber relações mais sutis entre as próprias cores dentro de um campo de visão, quer na proporção, quer na profundidade, quer no rebatimento em outras superfícies. 
NARRATIVAS VISUAIS

PERCURSOS 


\section{IDENTIDADE DO LGAR}

Gordon Cullen, em sua obra: Paisagem Urbana (CULLEN, G. Paisagem Urbana. Edicões 70: Lisboa. 1971) nos ilumina com a proposta da Visão Serial. Pela sua definição, através do percurso se revela uma sucessão de pontos de vista, que individualmente elegemos os ma is sugestivos e dramáticos pela alteração das profundidades e volumetrias, continuidades e desalinhamentos, aberturas e estreitamentos, saliências e reentrâncias que o trajeto nos proporciona. O olhar a tento proporciona uma experiência sensorial da cidade, "uma sensação de estara desvendar um mistério, de poder vir a descobrir sempre mais alguma coisa se continuarmosa andar" (CULLEN, 1971, p. 21). 

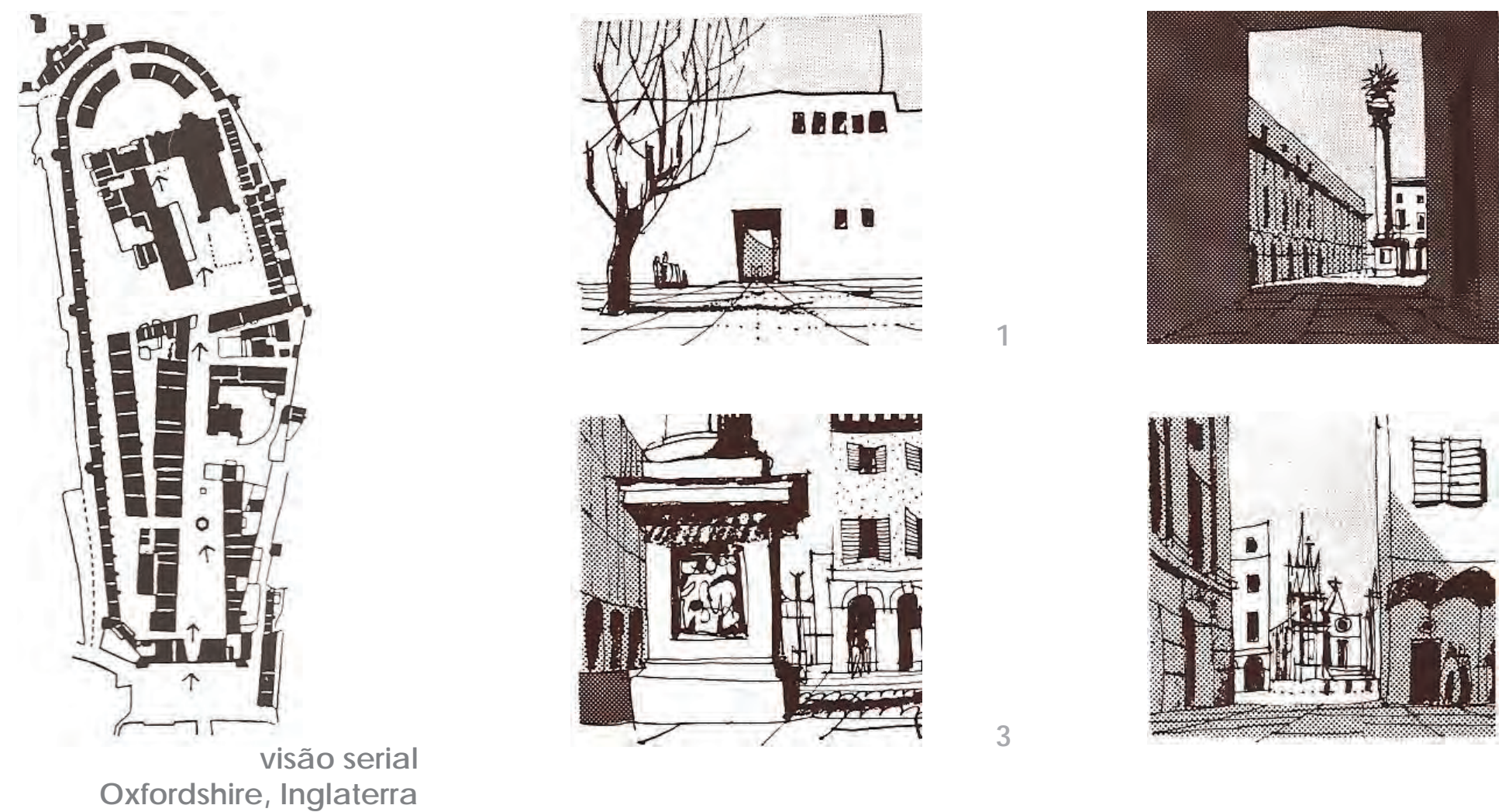

4
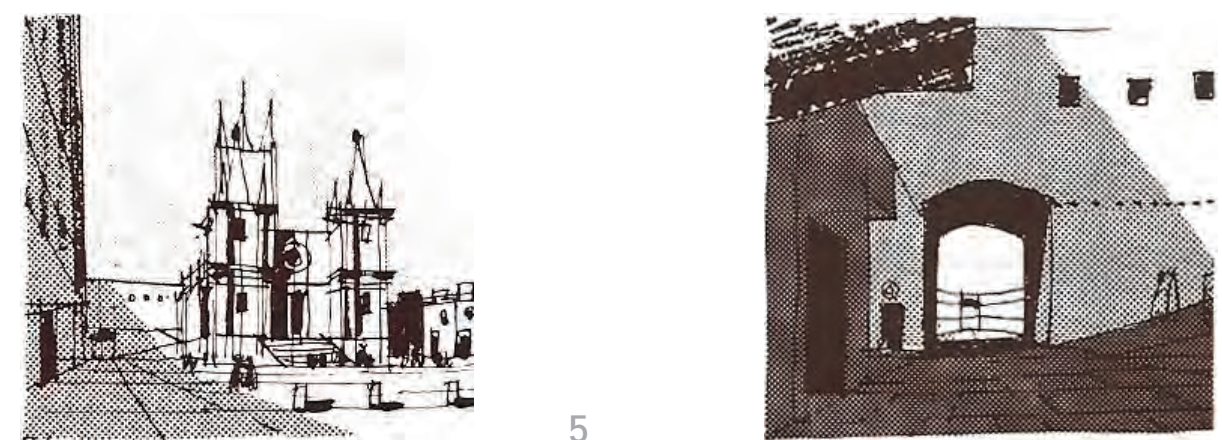
A ideia do percurso como forma de reconhecer e eleger elementos que constroem uma identidade, a paisagem específica da uma cidade, ou de parte dela, enfatiza outro pensamento do autor sobre o impacto visual da cidade sobre os seus habitantes ou visitantes. Através da arte do Relacionamento - como Cullen explica: cujo objetivo é a reunião dos elementos que concorrem para a criação de um a mbiente e que entretecendo esses elementos de ma neira a despartem emoção ou interesse e que individualiza o lugar, como sua cor, textura, escala, estilo, natureza, personalidade, etc.

A aplicação da Arte do Relacionamento faz com que se possa construir coerência e dramaticidade na construção do espaço urbano, impregnando-o de valor e atrativos perceptivos intuitivos, mesmo que a o transeunte possa pareceruma casualida de, coincidência ou sucessão de acontecimentos. É possível recriar no imaginário o lugar idealizado, tomando consciência de qua is elementos compõem o espaço e o resulta do de vá ria s opera ções relaciona is destes elementos. Essa talvez seja a maior contribuição do autor que nos instiga a perceber a cidade, e seus diferentes lugares, de uma maneira individualizada.

O recurso da fotografia nos remete diretamente a Susan Sontag (2004, p. 41): "fotografar é atribuir importância". A eleição de uma imagem, perante outras tantas, é também uma escala de valoração, que o olhar individual atrai, no qual se escolhe intuitivamente e que se determina como importância a ser mostrado a alguém. Ao se observar uma fotografia, logo se pensa sobre a origem da imagem produzida, pois ela retrata somente o fragmento de um todo que é o lugar.

A Cor também é fragmento desta imagem, que por vezes não se contem a forma delineadora - essas reflexões poéticas que a cor é capaz de impregnar o lugar é a peculiaridade que se buscou registrar. 
A cor adquire autonomia e estrutura, um fragmento da cidade, em contraste com o seu entorno, na sua opacidade, na sua reflexibilidade, que também varia durante o percurso do dia e da noite, transformando-se em outras relações que a forma sólida não pode se reproduzir ou ser multifacetária. Através do registro da fotografia, pela sua breve realização, proporciona que a cor do instante fotografado não altere drasticamente quando se realiza um percurso curto. Há de certo variações proporcionadas pela luz e pelos ângulos, mas o que se pretende captura é a relação entre ascorese sua percepção e os elementos plástic os dessas pa isa gens percorridas. 


\section{REGISTROS FOTOGRÁRCOS}

Entre os inúmeros vazios da cidade, as ruas se destacam.

A vida urbana tem nas ruas o pretexto do encontro, percurso ótimo do comércio e da vida mundana - cuja trajetória é herança do passado, da imposição topográfica ou da sociedade. 
Para quem percorre a rua, a graça da paisagem se deve, em boa parte, a visua is que de repente se abrem, revelando algo além ou um ângulo insuspeitado do conjunto urbano. Os c entros e bairros mais a ntigos a inda não sucumbiram a o traça do contemporâneo da linearidade das vias que exigem o a utomóvel, e permitem ainda as curvase a variedade das larguras que confere sabor ao longo do trajeto.

"Na trama urbana, amoldada ao sítio e irregular, a linearidade usual delas provém. Perfilam o c a sa rio na direçã o dospontosd e interesse e de conc entra çã o rea lç a nd o espigõ es, desc end o encostas, beijando várzeas. Mais do que o rego deixado pela via pública, o corpo contínuo e serpentea do do casa rio denuncia a o longe o c urso dasruas, nuelase becos. A direção ca pric hosa desse conjunto de cheios e vazios marca a personalidade da povoação e lhe dá a fisionomia própria" (p 43 in: Vazios - MARX, Murillo. Cidade Brasileira. São Paulo: Melhoramentos/ EDUSP, 1980).

Os percursos elaborados buscam olhar. Busca-se uma identidade do lugar, a memória do que ficou, a realidade de quem usa estas ruas de muitos transeuntes - cada qual com sua história e seus valores, que ora se identifica com a cidade, que ora se rebela contra ela.

Há muitos olhares. O importante aqui foi estabelecer aquilo que a cor tinha um papel de atenção ao olhar.

O Olhar nunca é único. 
mercado - rua 25 de março: $\mathbf{p . 5 9}$

mooca: $\mathbf{p . 6 3}$

ipiranga: $\mathbf{p . 6 7}$

bixiga: $\mathbf{p . 7 1}$

santa cecília: $\mathbf{p . 7 8}$

bom retiro: $\mathbf{p . 8 2}$

luz — rua são caetano: $\mathbf{p . 8 6}$

campos elíseos: $\mathbf{p . 9 1}$

liberdade: $\mathbf{p . 9 5}$

centro - república / anhangabaú: p.99 


\section{MERCADO}

\section{DE MARÇO}

Dentro do percurso que compreende a

Rua General Cameiro e

Rua da Cantareira, a Rua 25 de março talvez seja a mais significante.

A rua trata-se de um centro comercial - num marde gente onde coexistem em competição, os transeuntes, os a utomóveis, os ônibus, as ca miolas, os caminhos, as bicicletas de entrega e as barracas de ambulantes. 
Margeado por prédios e mais prédios com muitas portas abertas ao comércio de rua - cada qual tentando ser mais chamativa pelo barulho e pela cor destacada. Ao meio à turba de pessoas, os produtos expostos denotam ainda mais a diversidade cromática do lugar. No amarelo vivo do abacaxi exposto, nos colares purpuras da loja de fantasias, das paredes alaranjadas em contrate ao vendedor transvestido de Arlequim.

Pouco antes de 1850, a mais famosa rua comercial do país, era um grande rio com muitas curvas sinuosas que mais tarde foi retificado para descarregar as mercadorias importadas chegadas do Porto de Santos. Atualmente seus prédios dos mais diversos estilos, formas e tamanhos, contam a evolução urbana e história do lugar, como verdadeiro acervo cultural ao ar livre. Os prédios antigos permanecem, ainda, mas estão sujeitos ao gosto e aos modos de seus usuários e dos tempos da atualidade. 

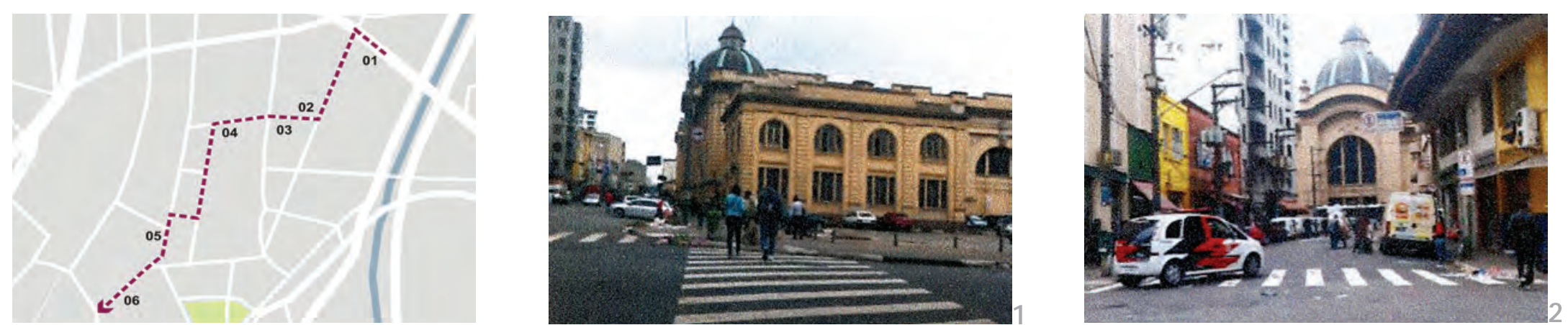

1. Avenida Mercúrio $x$ Rua da Cantareira (Mercado Municipal)

2. Rua Comendador Afonso Kherlakian $x$ Rua da Cantareira

3. Rua Comendador Afonso Kherlakian $x$ Rua Barão de Duprat

4. Rua Comendador Afonso Kherlakian $x$ Rua Comendador Abdo Schahin (Galeria Pajé)

5. Rua 25 de Março (próximo à ladeira de Porto Geral)

6. Ladeira Constituição $x$ Rua 25 de Março
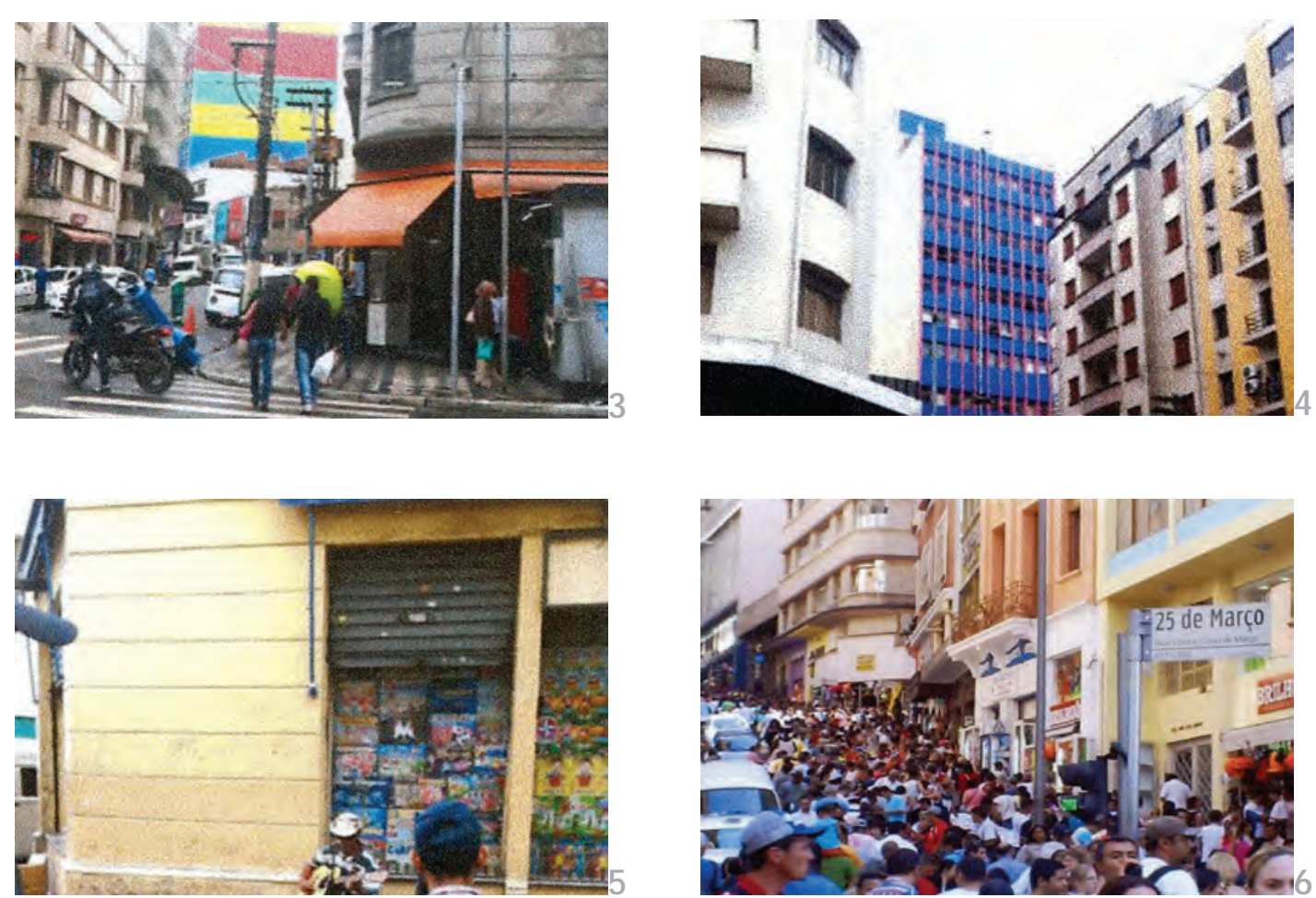


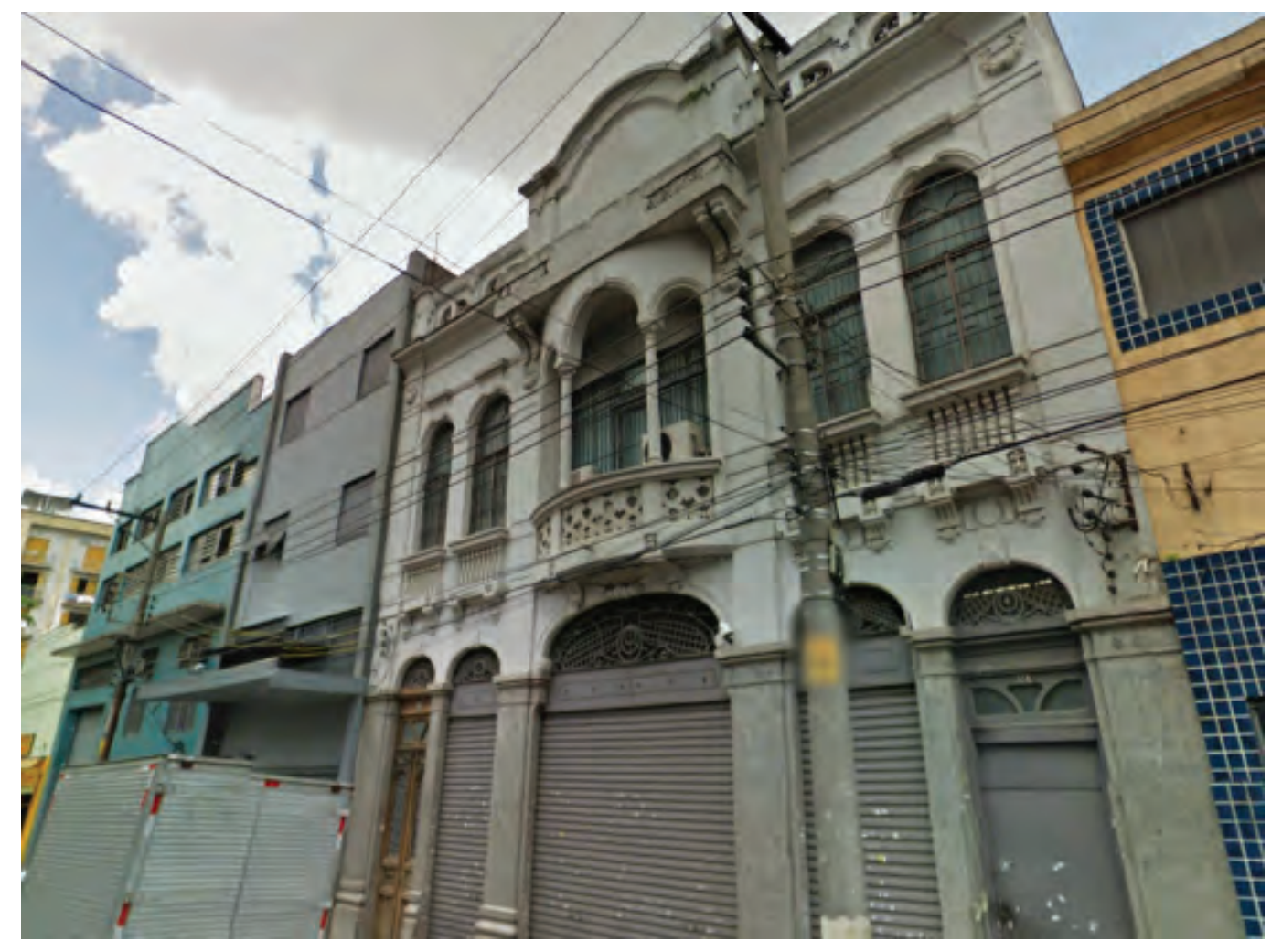




\section{MOOCA}

Enqua nto parte do bairro vive a excentricidade de uma expansão, a inda restam remanescentes de uma época operária. O bairro que se desenvolveu, sobretudo através das indústrias que contrastam com os pequenos lotes destina dos às casas operárias. Numa mesma rua em que se observa a grande dimensão dos galpões desocupados, em telhados em sheed e tijolo aparente, se vê as moradiasbaixas ou assobradadas.

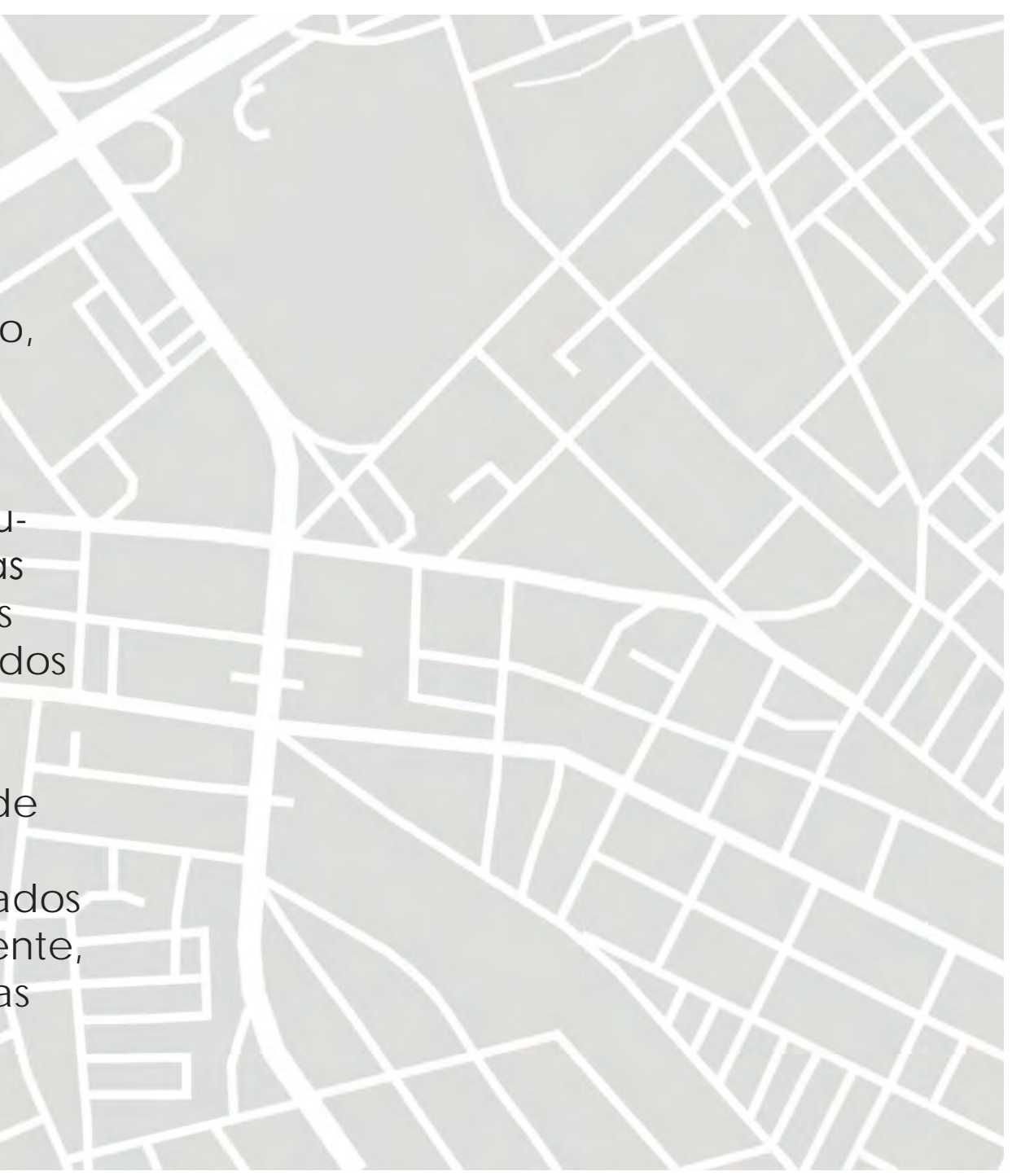


Muitas moradias se tomaram comérc io ou senviço e assim a dotaram uma diversidade de cores para que se possa identifica-las dentre os grupos geminados de mesma tipologia. Algumas permanecem como habitação, qua se sempre decadentes, mas ainda com os omamentos típicos de um período que utilizava bem o tijolo aparente, a massa cal e os afrescos trazidos pelo gosto do imigrante italiano.

Osita lia nos trouxeram pa ra a região nã o somente o pensa mento sindic a lista e soc ia lista, po rém também hábitos do uso do espaço da rua para conviver - seja nas cadeiras dispostas nas calçadas ao fim do dia para conversar com o vizinho, seja no passeio a pé de grupos das mais jovens a serem cortejadas pelos solteiros.

Nas ruas mais internas, há um apuramento na qualidade das fachadas e das calçadas - que ainda permanece. O conjunto do casario denota bem a ideia de comunidade, com a continuidade do padrão cromático — uma herança europeia, mas se vê ponteado aqui e ali, algo que dá identidade a unidade: um vaso de plantas, uma calcada decorada, um portão bem desenhado.

Observa-se a inda a permanência dosgalpõesindustria is, que estão a ba ndona dosem grandes lotes ou que já sofreram intervenção para outras funções. a cor de tijolo é constante e se repete em outros tipos de edificações. 

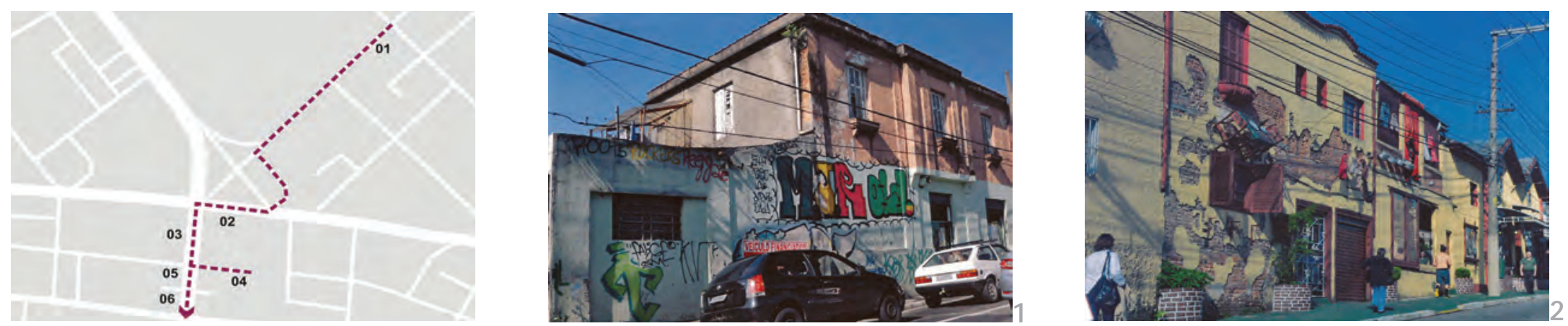

1. Rua Taquari (casanio)

2. Rua dos Trilhos (casario)

3. Rua Taquari (galpão industrial)

4. Rua Javari (antigo Cotonifício Crespi)
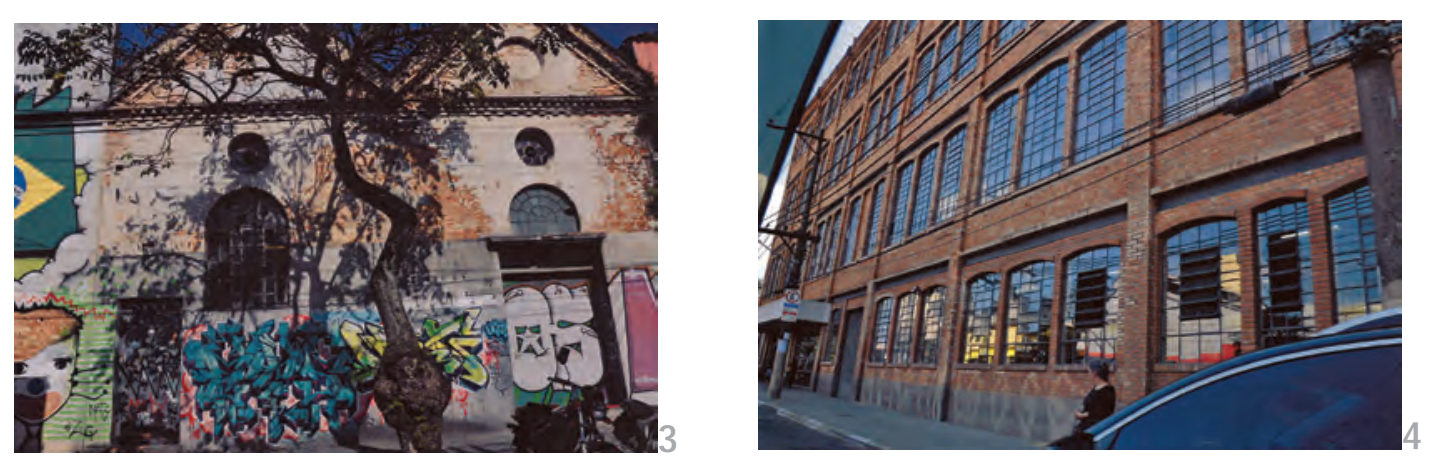

5. Rua Taquari x Rua Javari (antiga tec elagem)

6. Rua da Mooca

(detalhe da antiga tecelagem)
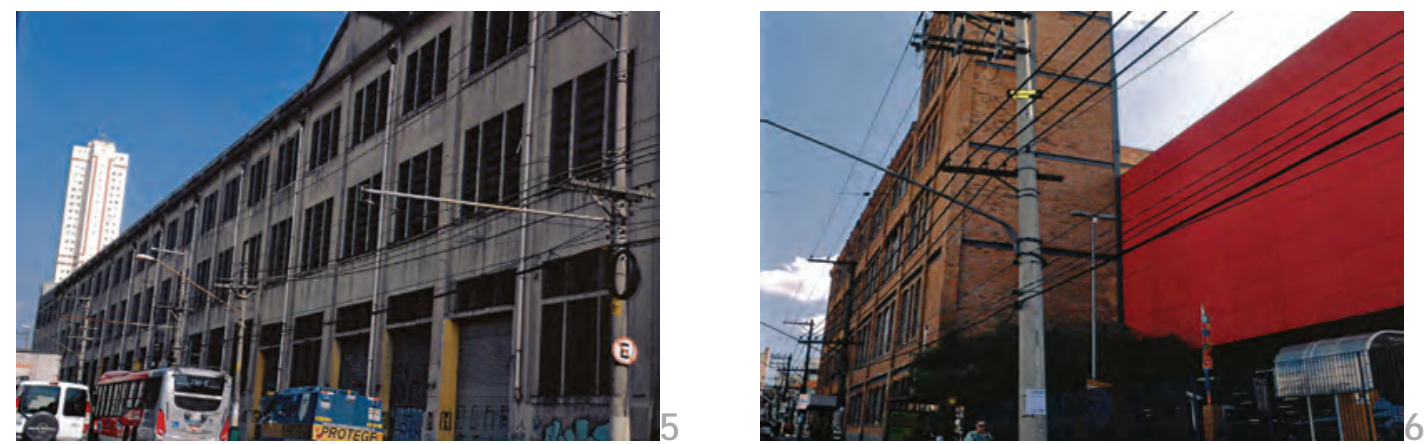


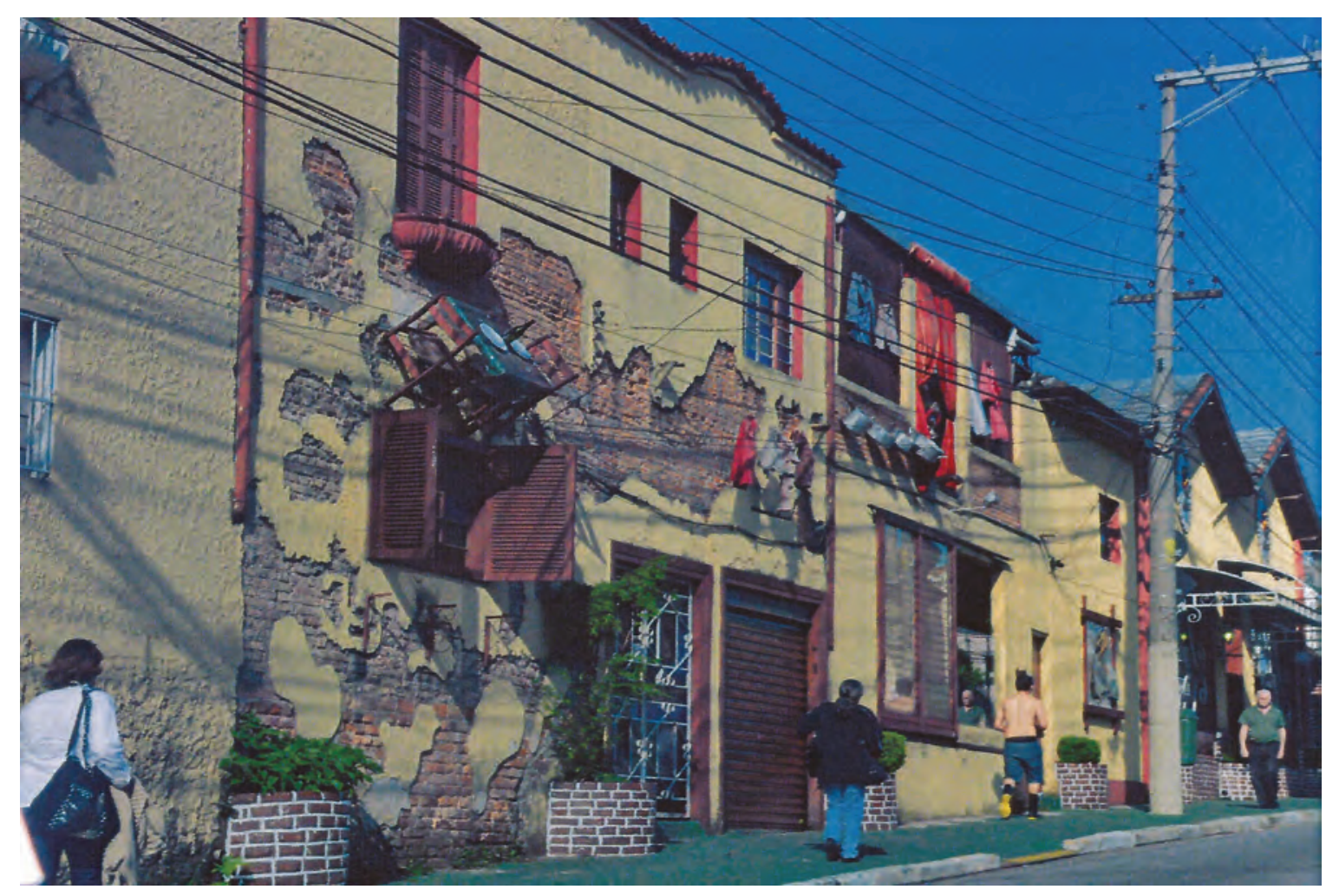




\section{IPIRANGA}

O bairro tem sua história desde o início associada aos deslocamentos entre a capital e o litoral paulista, através da Serra do Mar em direção à Baixada Santista - fazendo-o cenário históric o no periodo do Império. Atualmente é dividido em subdistritose cada qual tem sua própria personalidade conforme a população ali instalada. Optou-se porobservaras áreas de entomo ao Museu do Ipiranga, pela maior incidência de visita ntese diversida de de tipologias que a inda permanecem no bairro. 
Existe no mesmo local a situação de fim de semana e feriados, em que absorve toda gente vinda aos parques locais - do próprio bairro, dos vizinhos, de outros municípios e estados e, ainda, muitos estrangeiros. Nestes dias as barracas coloridas, de toda sorte de badulaques, tomam o local e a vizinhança. As crianças correm soltas, os idosos sentam à sombra e há muitos desportistas funcionais e de última hora. Há cantoria de viola, dança folclórica, pajelança e pregação.

No dia de semana, é possível caminhar e observar com mais atenção. Ainda permanecem antigos palacetes que se tomaram instituições, e instituições que se tomaram apenas muros grafitados por quem passa por ali. Os casarios são de diferentes épocas, de influência italiana, espanhola, libanesa - algumas habitações modernistas.

Cada qual com sua própria linguagem arquitetônica onde permanecem os ma teria is origina is e, portanto, com suas cores neutras típicas - os cimentados com mica, o caiamento de cal tingida, as pedras naturais, as pastilhas cerâmicas, os gradis.

Paralelas, a Rua Bom Pastor e a Avenida Dom Pedro I ficaram caracterizados por casarões de famílias abastadas e pela classe média que trabalhava nas muitas fábricas do bairro. Na Avenida Nazaré, que corria ao longo do topo da colina do Ipiranga, instituições de ensino ou caridade ligadas à Igreja Católica despontam, ocupando parte do espaço. De modo geral, todas em cores mornas de mesmos tons, talvez marcas de suasidentida des de origem, empregam um ar de unidade à avenida.

As moradias que se tornaram comércio - sobretudo os restaurantes - assumem cores fortes, ainda que austeras.

O parque tem uma presença marcante e possibilita a abertura do campo de visão através deles, proporcionando profundidade e vistas de mais longe. Como obra pública, já foi de várias cores - do tempo de criança me lembro do alaranjado, ocre, amarelo claro ao branco. E mesmo envolto na vegetação, sua vizinhança foi alternando igualmente a cor de suas fachadas, buscando uma harmonização dissimulada. 

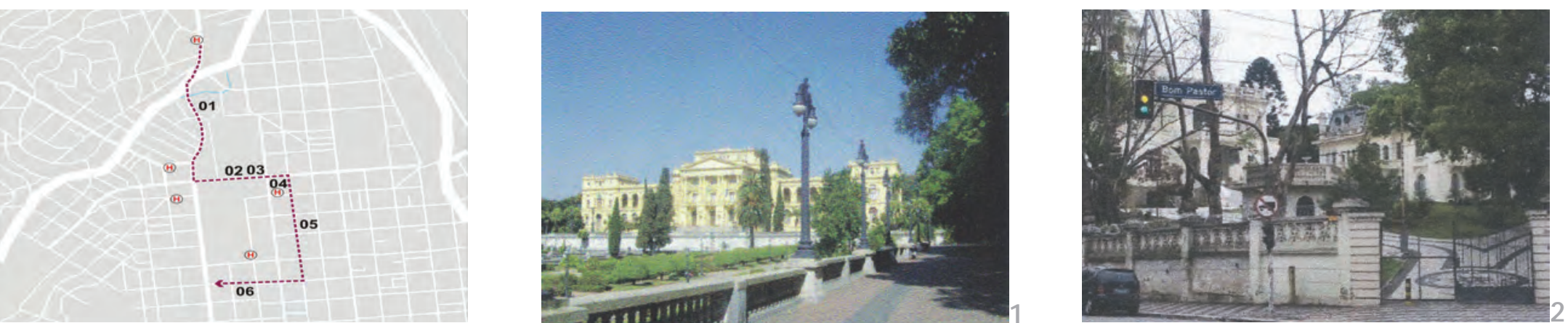

1. Rua do Monumento

(continuação da Av. D. Pedro I e

Av. Nazaré - Museu do lpiranga)

2. Rua dos Patriotas $\mathbf{X}$

Rua Bom Pastor

3. Rua dos Patriotas

(detalhe do piso de palacete)

4. Rua Bom Pastor (palacete)

5. Rua Costa Aguiar

(moradia e comércio)

6. Rua Moreira e Costa
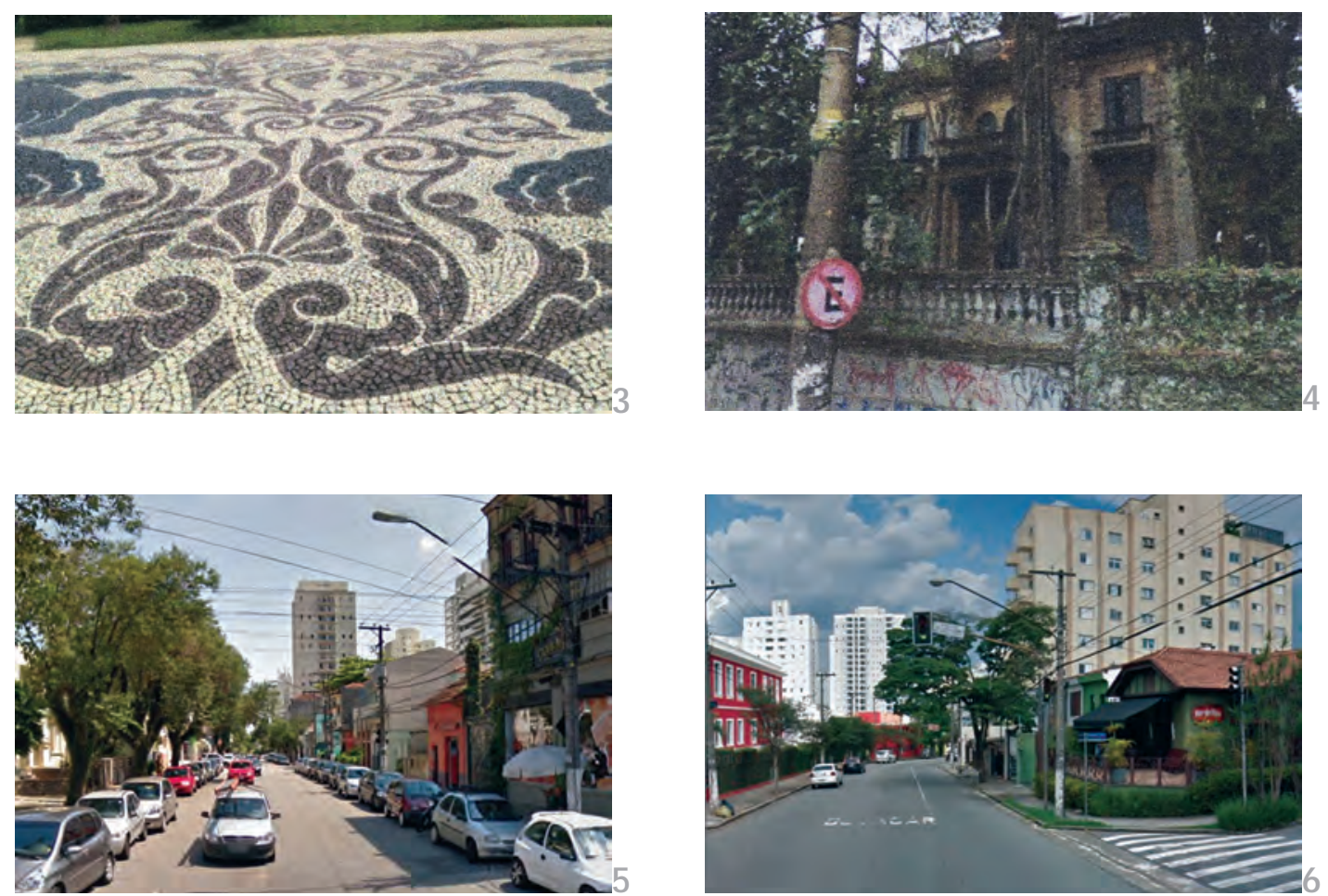


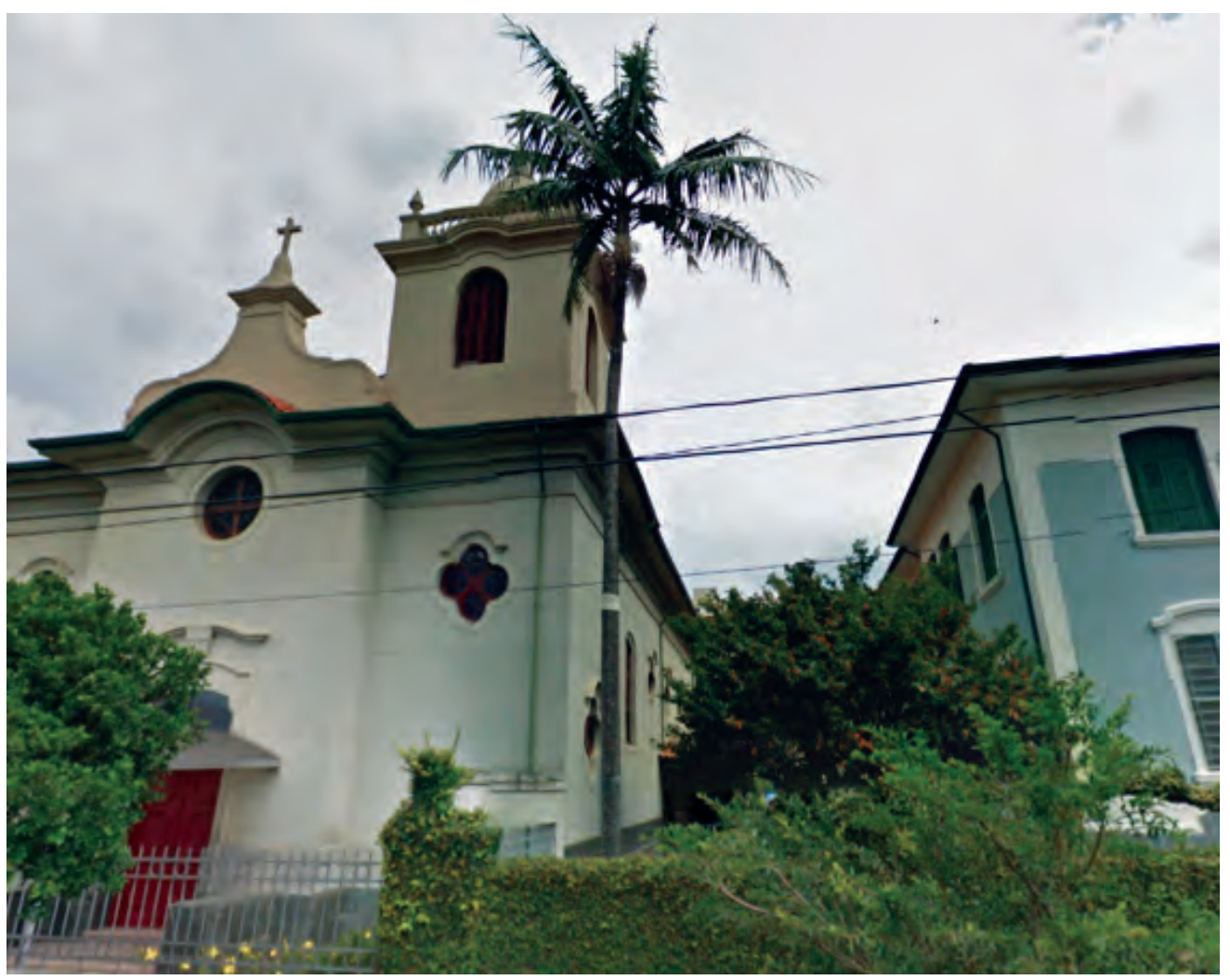




\section{BIXIGA}

Composto porpequenos lotes, interessaram pelo baixo valor a os recém-chegados imigra ntes italia nos, na maior parte oriundos da região da Calábria tra dic iona Imente católicos fervorosos e de tradição festiva. Assim, observam-se as inúmeras cantinas, a vida boêmia e familiar acontec er em suas ruas que se transformam em procissão em homenagem à padroeira Nossa Senhora Achiropita, mas ta mbém em passagem de ensaio de Camaval da escola de samba local Vai-Vai.

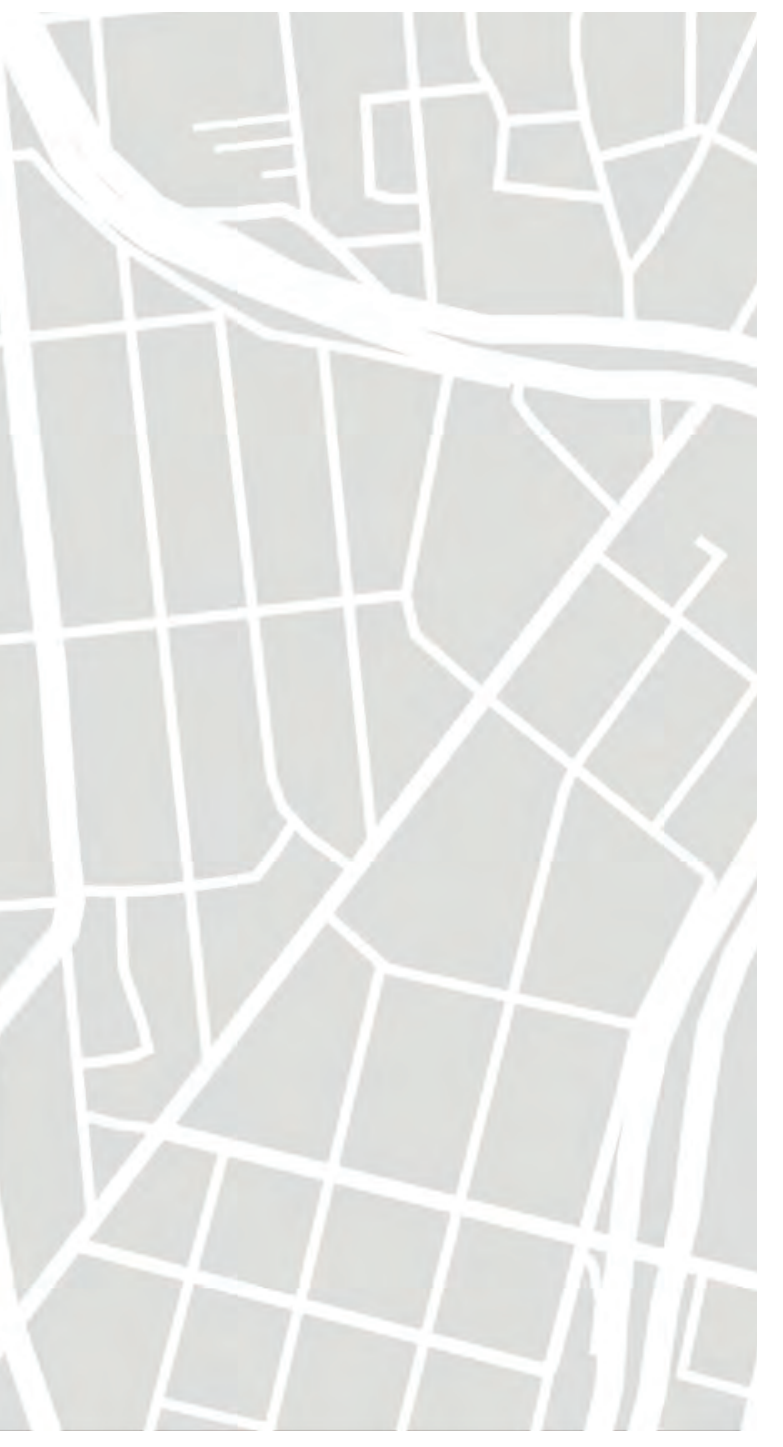


Um dos mais tradicionais bairros paulistanos, ganhou importância histórica e turística, por onde perambula-se pelos diversos atrativos locais - os teatros, as cantinas muito coloridas, as ruas enfeitadas com bandeirolas rubro-verdes, as praças arborizadas com suas barracas de antiguidade, as escadarias para se sentar e ver o outro passar, as colunas do viaduto 9 de julho que de tempos em tempos recebem intervenções de artista s locais, o ca sa rio tra dicional com suas janelas, em venezianas que abrem para fora, sobre bandeiras de vitrais.

Assim como a diversidade de gradis e portões desenhados em ferro fundido, quase sempre na cor chumbo, há muito estuque e afrescos que os habilidosos mestres italianos trouxeram para suas modestas moradiase que também habilitaram a produção do importante Liceu de Artes e Ofícios.

A topografia é algo típico que identifica o lugar. As ruas sobem em direção à Rua 13 de maio - sempre muito enfeitada - , e o casario serpenteia junto, colado um a um, em conjunto que lembram uma unidade, sobretudo com a cor mantida como única ao grupo, dando a sensação de continuidade que por vezes é interrompida por outra moradia.

Independente do movimento do comércio e dos visitantes do bairro, a vizinhança participa sempre do espaço comum de convivência que é a rua - o local do encontro e da conversa. Por isto se vê mais a conservação das edificações, o "enfeite", e a preservação dos valores comuns - incluindo nisto certa hegemonia dos tons cromáticos, como identidade de um grupo.

Apesar da viviacida de da região, há a inda a lguns cortiços em áreas a bandona dase devido a proximidade do bairro ao centro da cidade. É um tanto curioso observar que a situação do cortiço não avanca o domínio público da rua, como acontece em áreas invadidas do Glicério, Brás ou Luz. A rua efetivamente é de todos e cuidada como um patrimônio comum. 


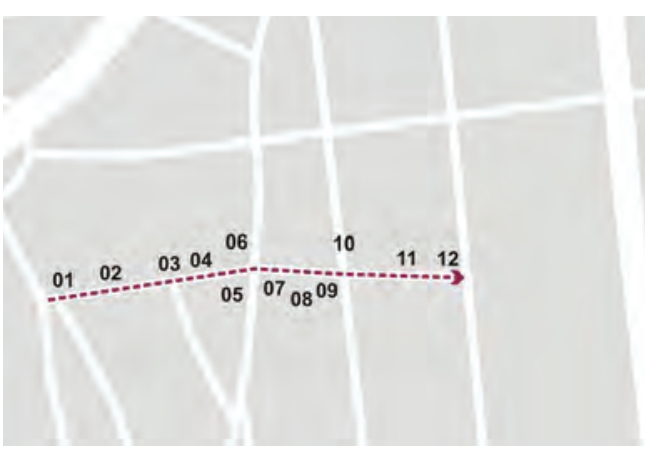

TRAJETO 1

1. Rua São Vicente $x$ Rua Cardeal Leme $x$

Rua Dr. Lourenço Granato

2. Rua São Vic ente

3. Rua São Vic ente $x$ Rua J osé Tenaglia

4. Rua São Vicente (detalhe - portão de casario)

5. Rua São Vicente $x$ Rua Santo Antônio

6. Rua São Vic ente

(vista para Rua Santo Antônio)
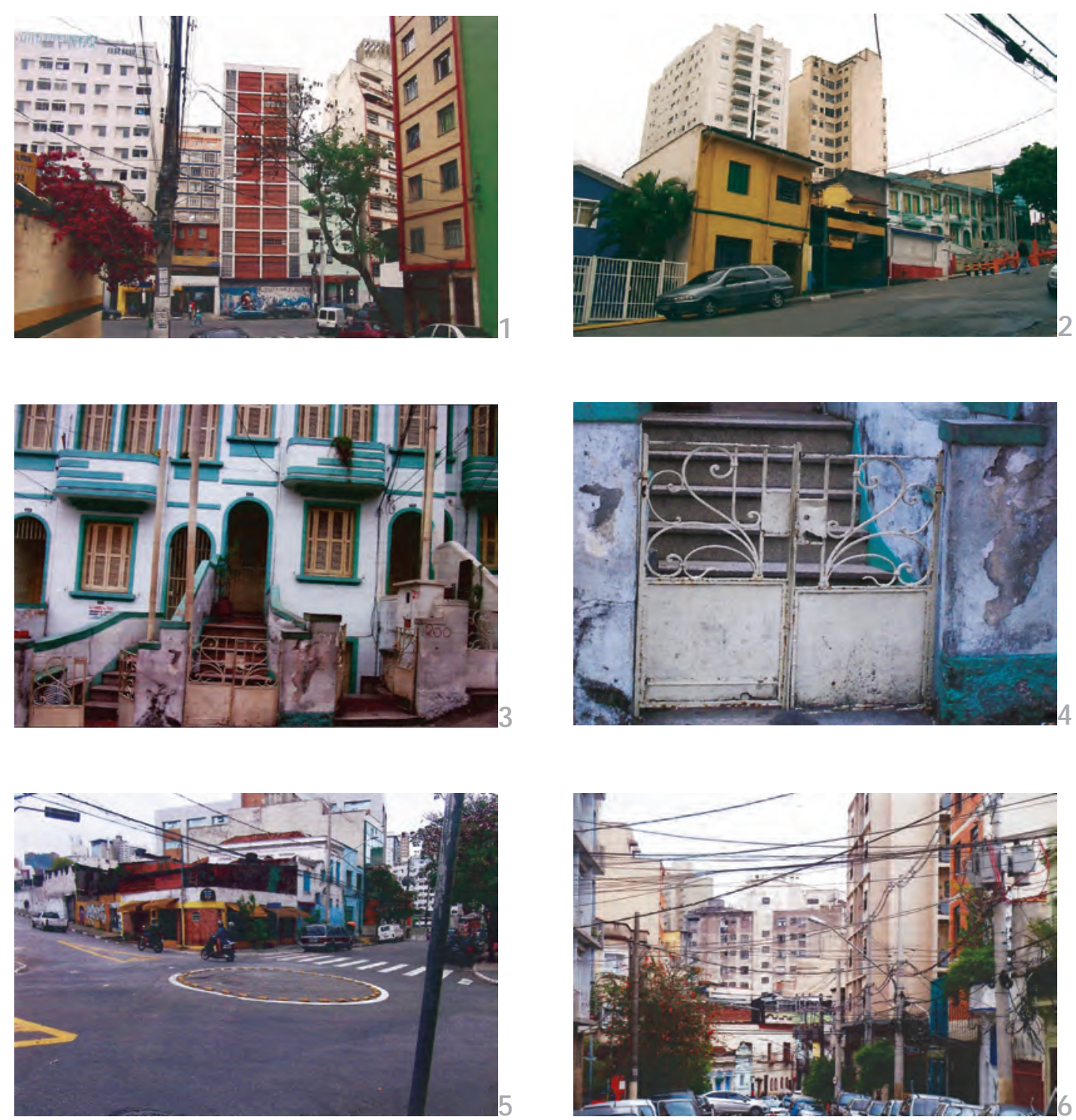


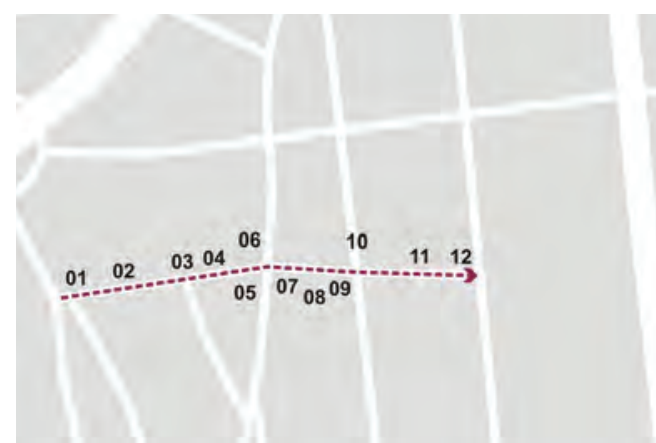

7. Rua São Vic ente

8. Rua São Vic ente (casario)

9. Rua São Vic ente $x$ Rua Dr. Luís Barreto

10. Rua São Vicente (vista para Rua Dr. Luís Barreto)

11. Rua São Vicente (comércio/habitação)

12. Rua São Vicente $x$ Rua 13 de Maio

(detalhe - fachada da esquina)
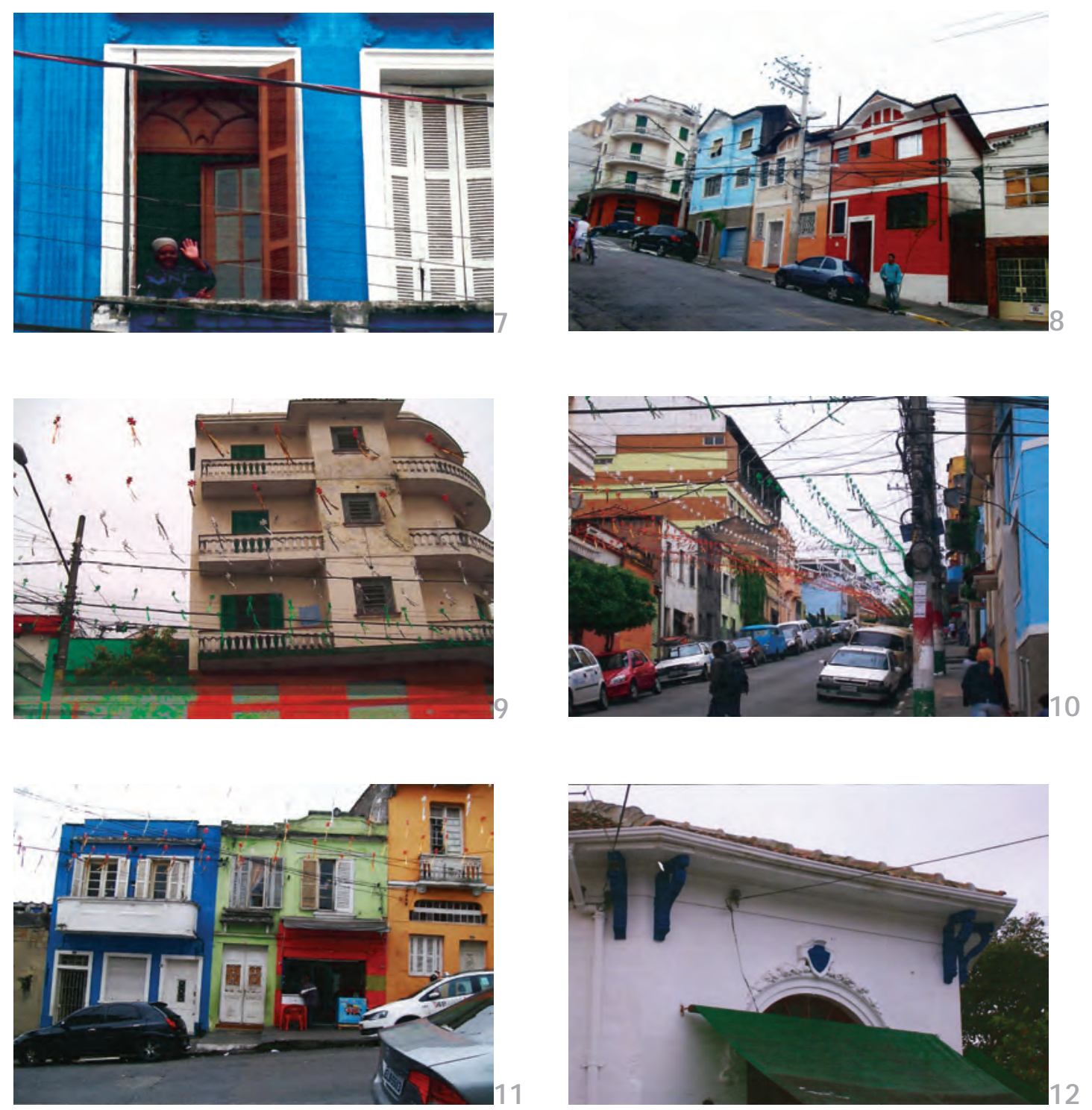

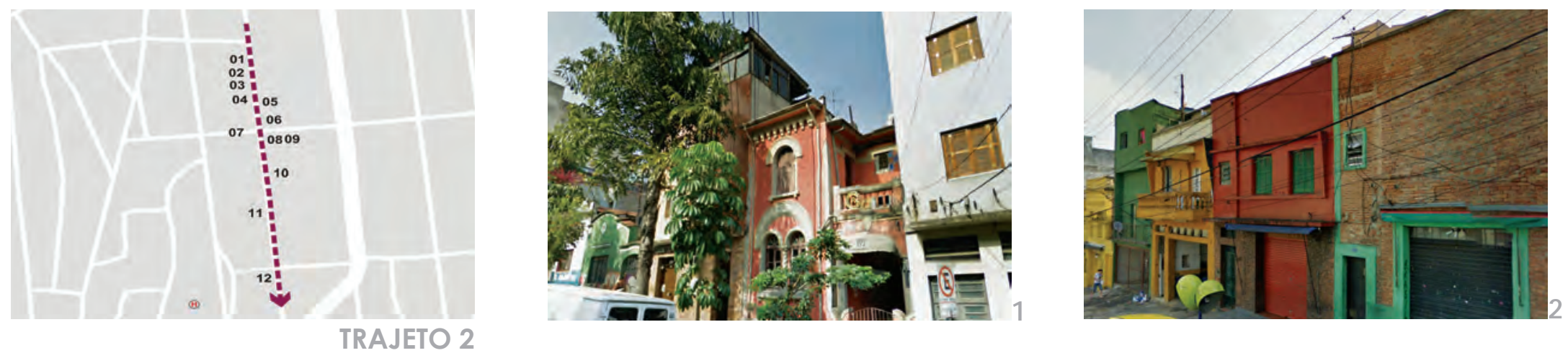

1. Rua 13 de Maio (casario típico)

2. Rua 13 de Maio (comércio local)

3. Rua 13 de Maio

4. Rua 13 de Maio (Igreja Nossa Senhora Achiropita)
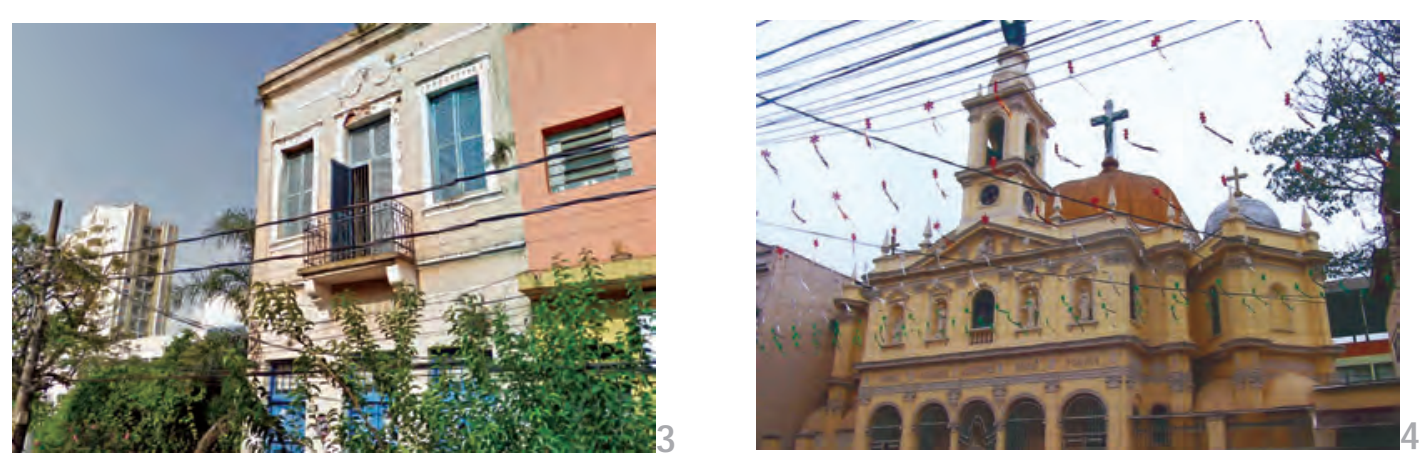

5. Rua 13 de Maio

6. Rua 13 de Maio $x$

Rua Conselheiro Ca rão

(comércio e serviços-

restaurantes típicos)
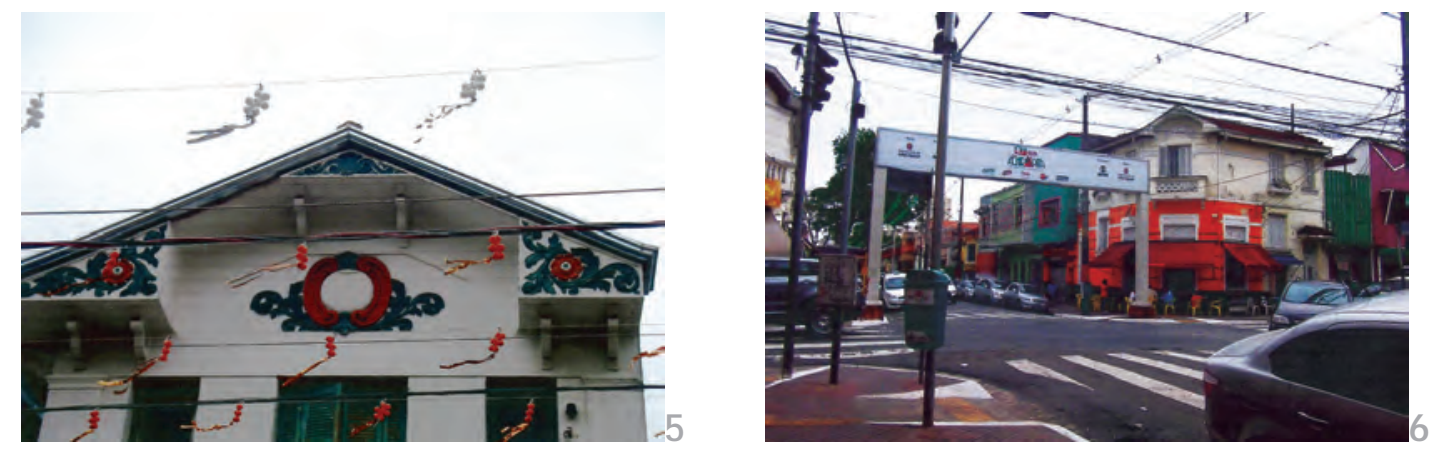

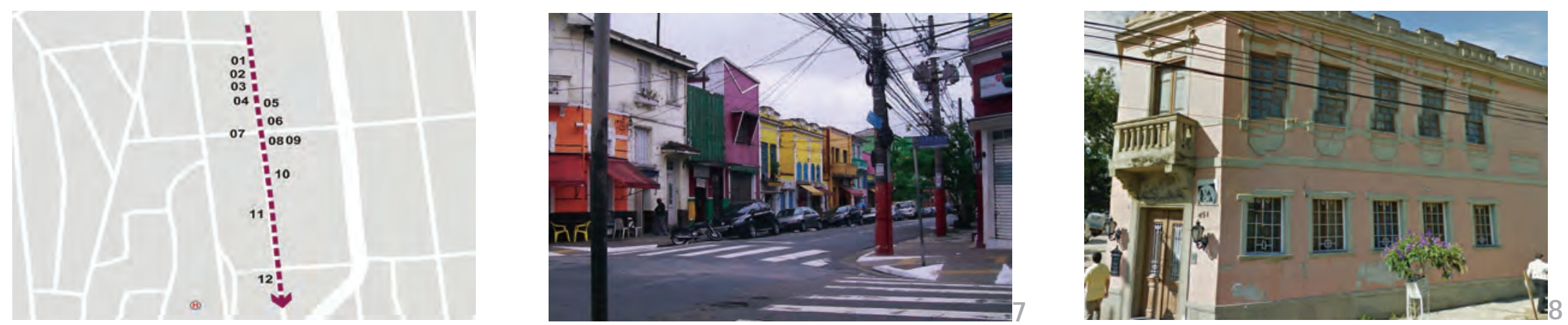

7. Rua 13 de Maio $x$

Rua Conselheiro Carrão (vista para a rua Cons. Carrão)

8. Rua 13 de Maio $x$

Rua Conselheiro Carrão (esquina oposta)

9. Rua 13 de Maio

(detalhe - luminária de casario)

10. Rua 13 de Maio (comércio e habitação)

11. Rua 13 de Maio (casario)

12. Rua 13 de Maio $x$ Praça Dom Orione (Museu de Culinária e Gastronomia Italiana - próximo a escadaria para Rua dos Ingleses)
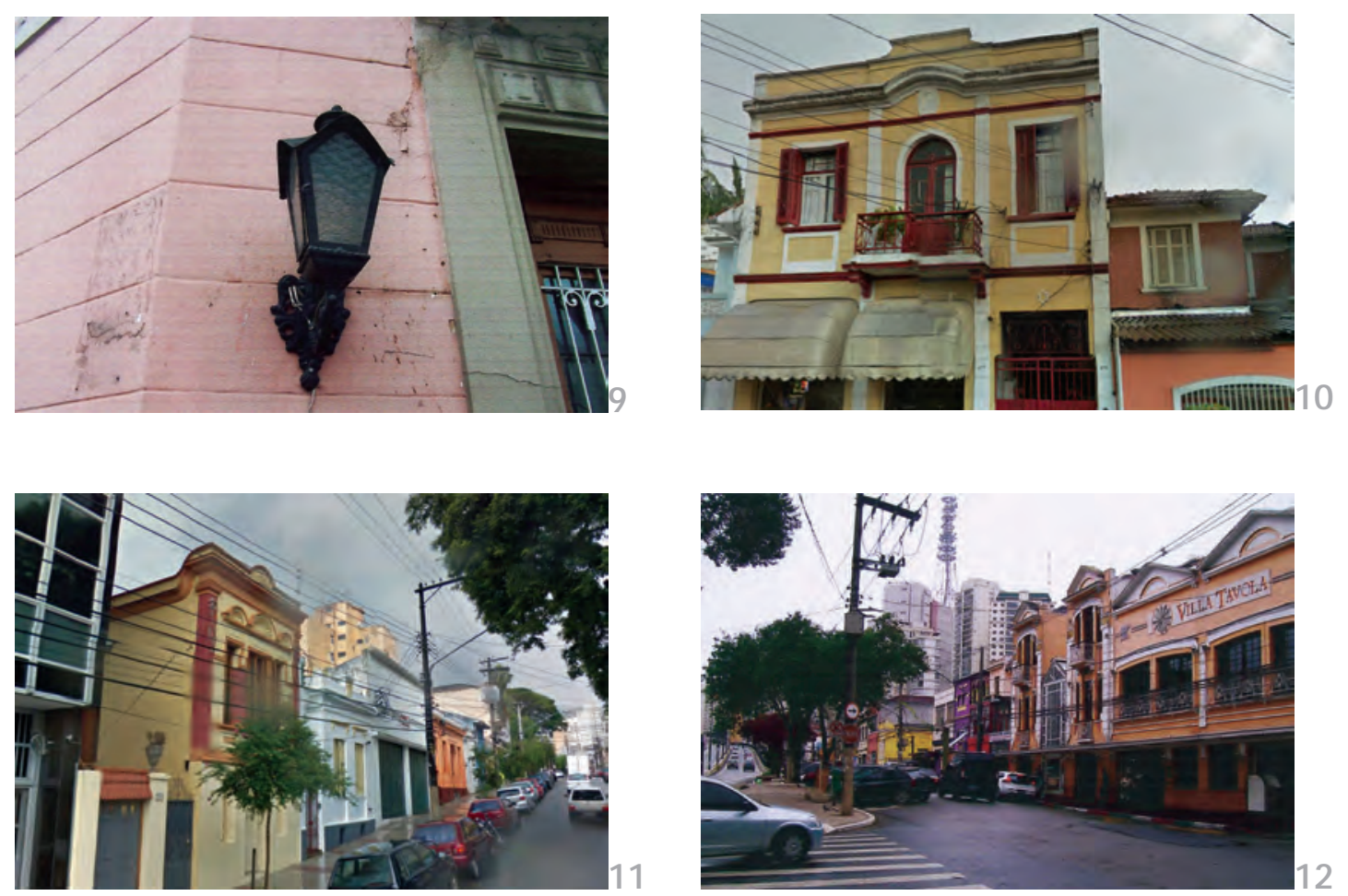


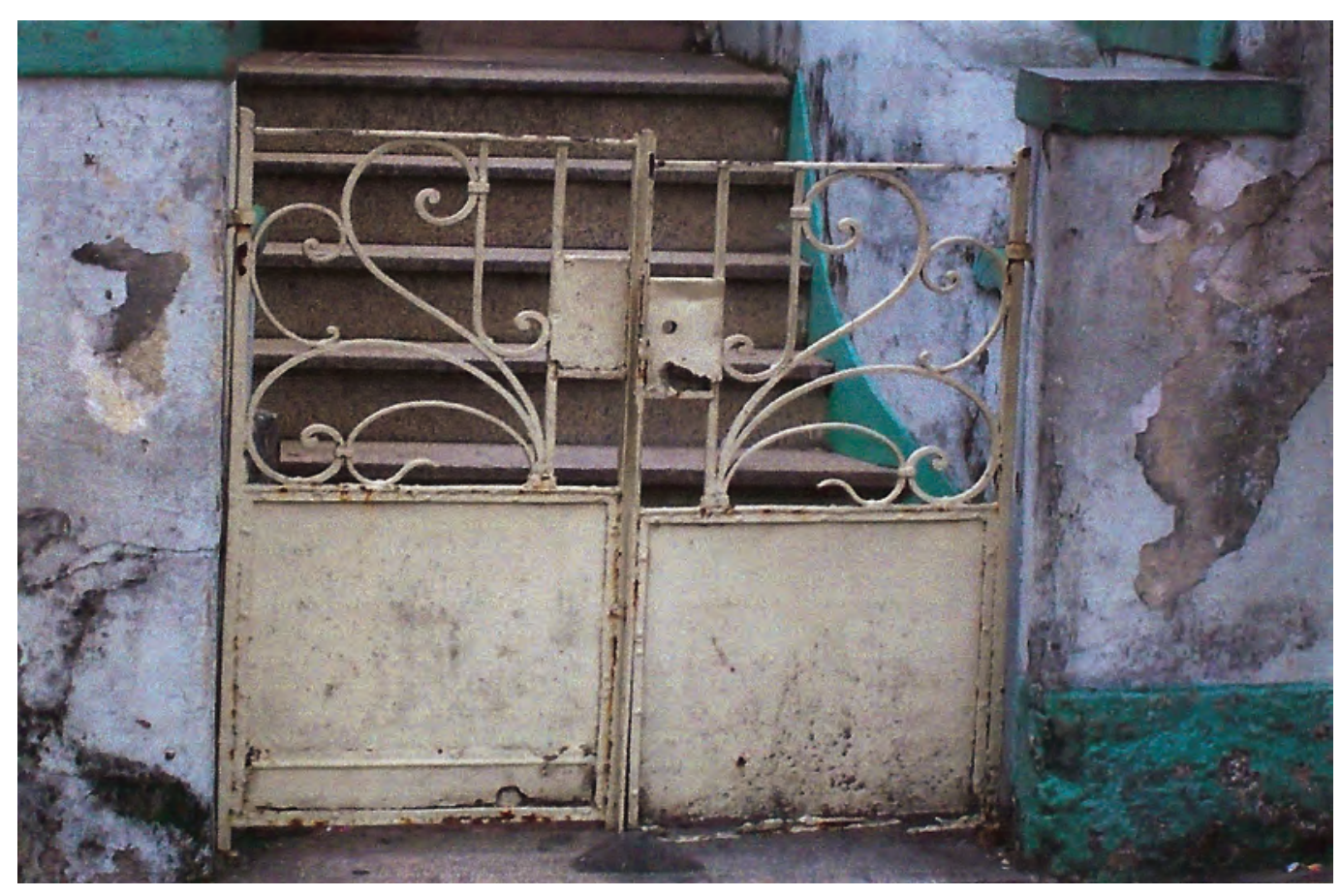




\section{SANTA CECÍLA}

Próximo à área central da cidade, vizinho a Higienópolis - bairro de alto padrão aquisitivo e beirando o elevado Presidente Costa e Silva (Minhocão), que liga a cidade no sentido Leste-Oeste.
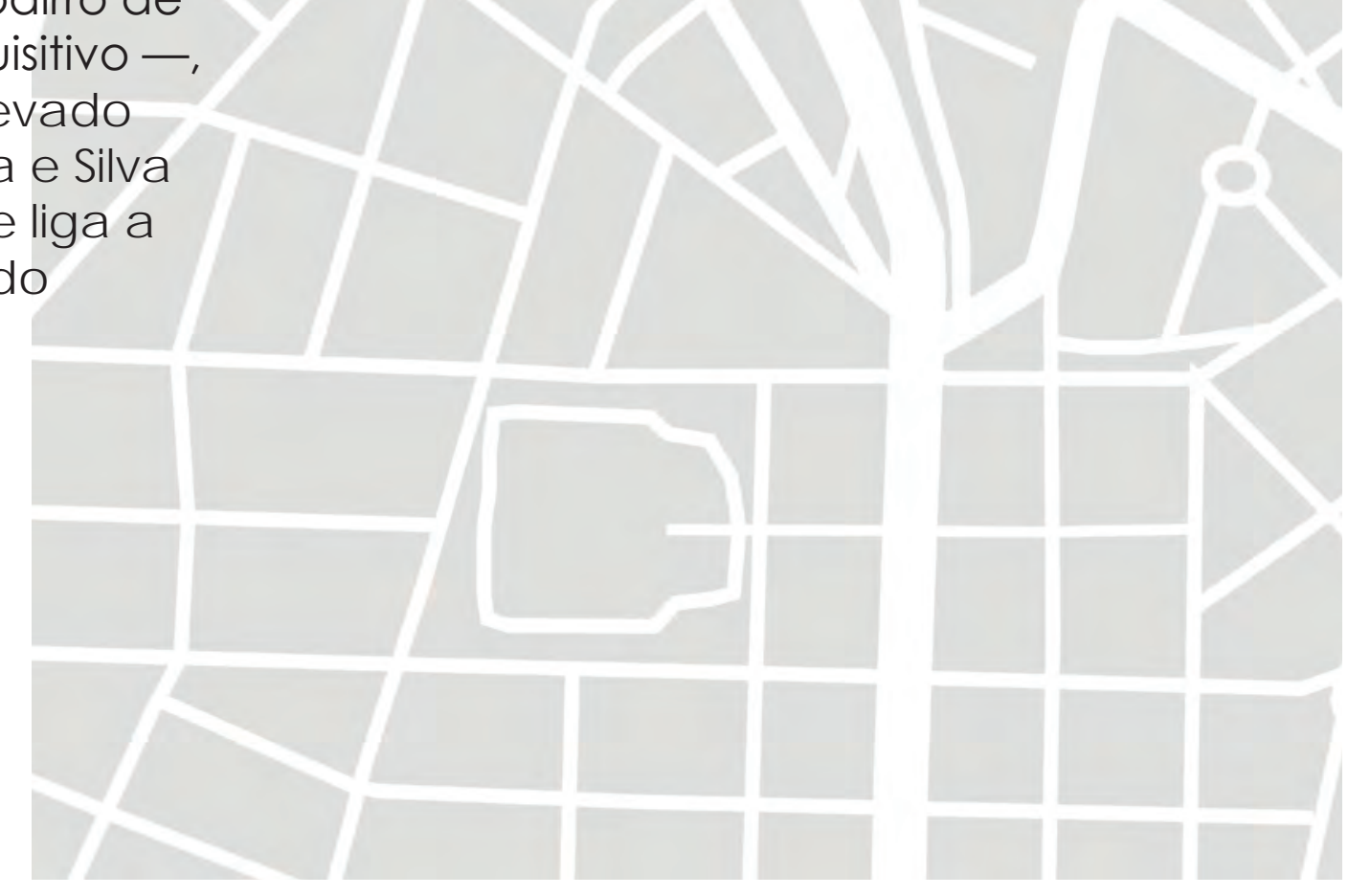
Já houve um tempo de explendor, quando fazendeiros do café vindos do interior se instalaram na região em espaçosos terrenos ideiais para mansões e residências para temporadas na capital. As mansões foram demolidas devido às crises econômicas, dando lugar a uma pluralidade de edifícios da década de 30 e 40.

O esvaziamento do centro da cidade e a especificidade dos edifícios sem garagem fizeram com que a classe média se afastasse da região, apesar de importantes equipamentos urbanos existentes como o Hospital da Santa Casa, instituições clericais de ensino e o metrô.

O que se observa é que se tornou um local de passagem - de transeuntes que utilizam a estação metroviária ou o próprio minhocão, muito escuro e um tanto insólito pela proximidade à sua vizinhança degradada do centro.

Há os moradores das muitas janelas iguais, contomadas em pastilhas ceramicas de cores pálidas que bem lembram as louças de tias e avós; e os pequenos estabelecimentos, incrustrados entre os edifícios, que tendem a ter uma distinção de seu uso pela cor mais chamativa. Forma-se um contraste interessante pela proporção que estabelecem entre si. Ou mesmo os grafites e pixações que seguem pelos vários muros e pilares estruturais do elevado.

À noite é algo à parte. O movimento cai ao fim do horário comercial de expediente, as boates e botecosse abrem, dando lugar a outro tipo de gente, muitos ma rginaliza dose transvestidos para o burburinho da noite boêmia.

Os padrões cromáticos se repetem quase que cadenciadamente pelos edifícios enfileirados. Há somente um resquício da parte antiga do bairro, próxima à Avenida Angélica e Alameda Barros, onde o Externato e as residências de porte permanecem.

O movimento existente na Avenida Angélica e na estação de metrô se esvai conforme findo o dia, as pessoas somem das ruas e pouco se vê do bairro - uma ou outra intervenção mais pontual que poderia fazer referência à memória, fora o sentido da Santa Casa em seus tijolos aparentes que sempre se prestou em serviço e referência ao lugar. 

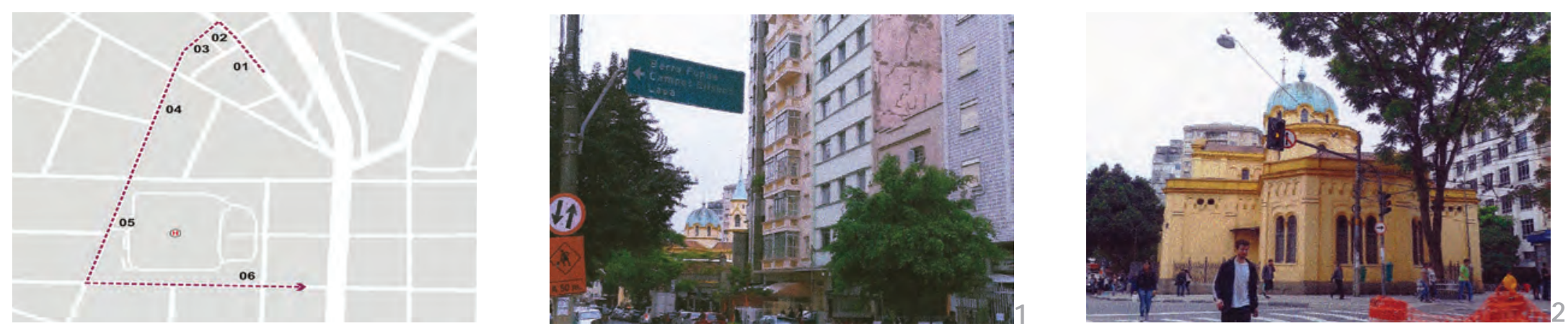

1. Rua Sebastião Salgado

2. Largo Santa Cecília (Igreja de Santa Cecília)

3. Largo Santa Cecília (torre da igreja/entrada do metrô)

4. Rua Dona Veridiana (habitação)

5. Rua Dona Veridiana (muros da Santa Casa/entrada do Hospital Santa Isabel)

6. Rua Marquês de Itu $x$ Rua Dr. Cesário Mota Jr. (entrada da Santa Casa de Miseric órdia)
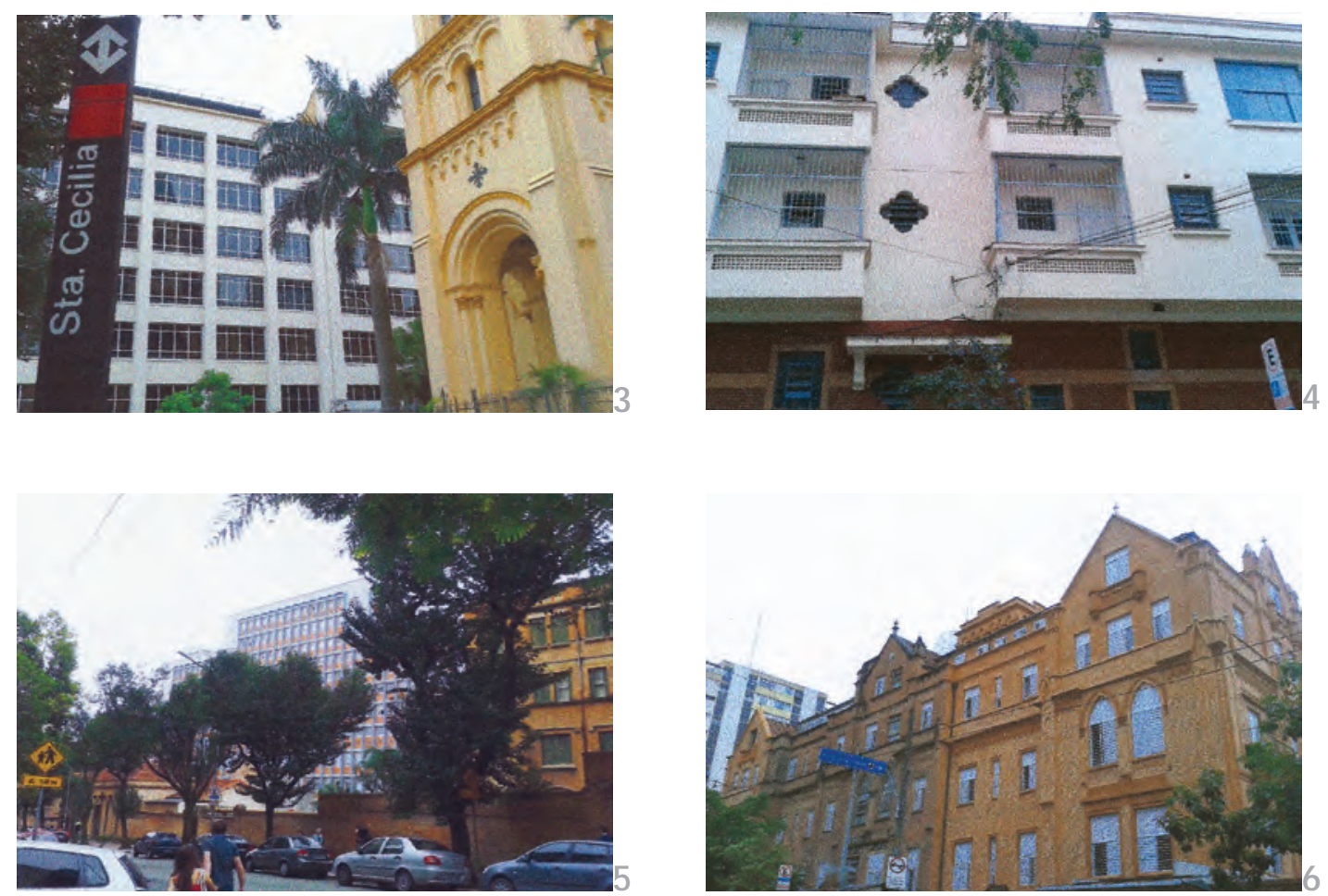


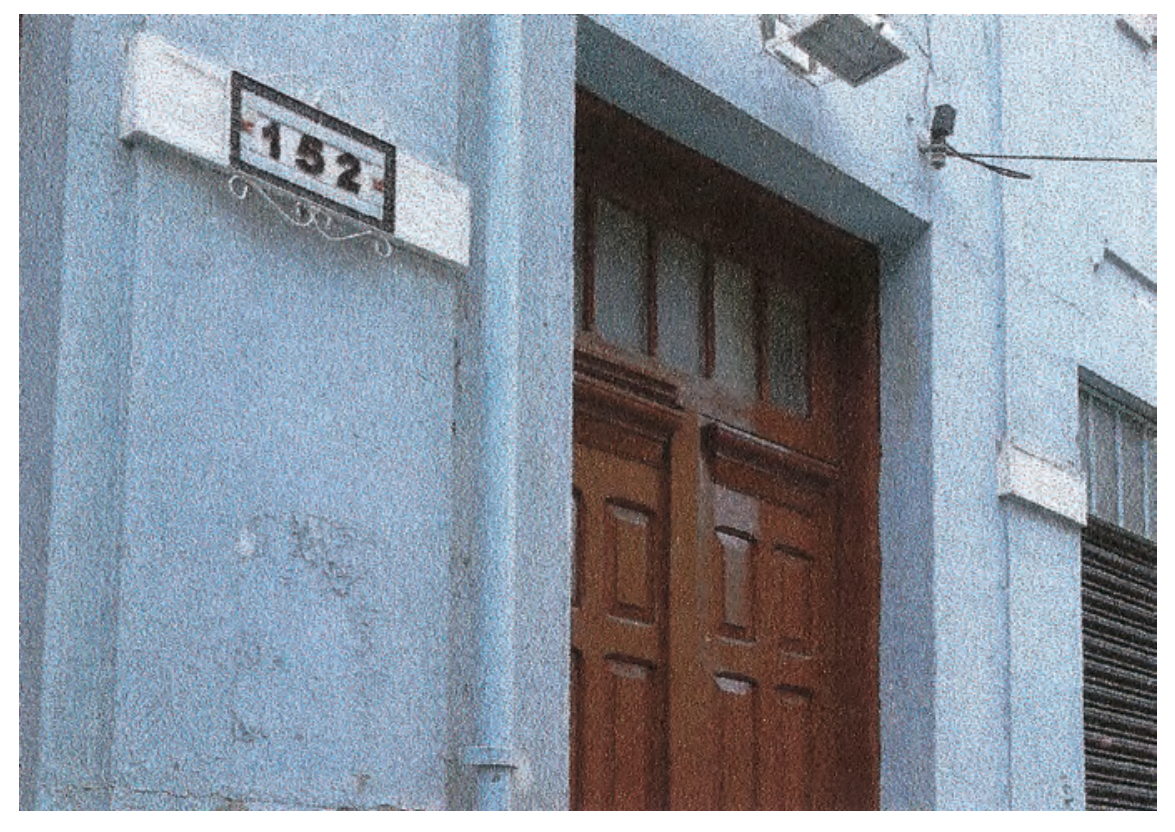




\section{BOM REIRO}

Essencialmente comercial, com á reas ind ustria ise residencia is, destaca-se aqui a região da Rua José Paulino com suas lojas enfileriadas ombro a ombro, e cobertas de merc a dorias voltadasa moda e a o vestuário, e da Rua Prates, onde estão as oficinas/atelieres, sobrema neira voltadasao vestuá rio, e muitas residencias de diferentes períodos.

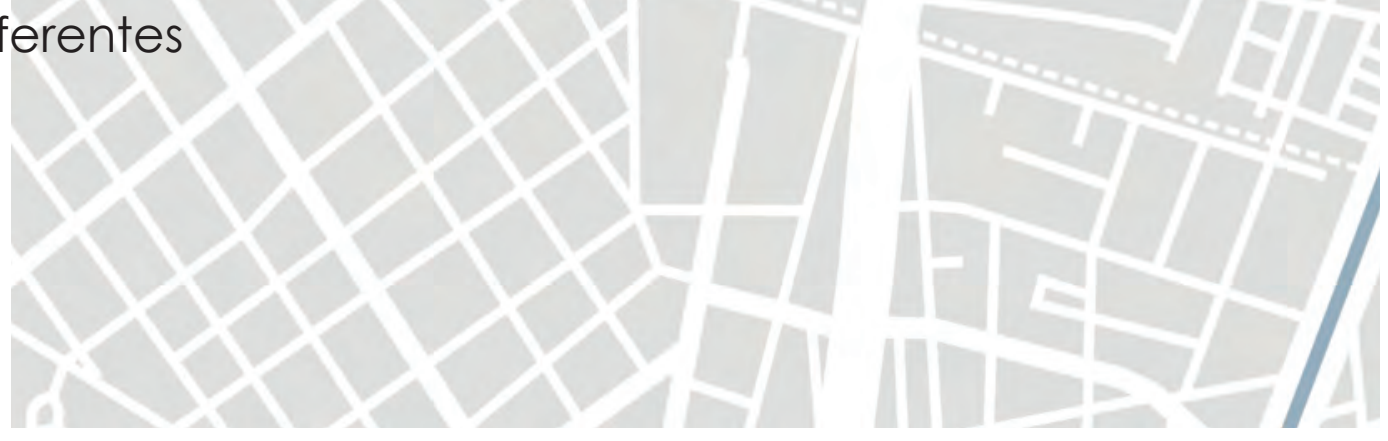


Além da questão das muitas comunidades étnicas que compuseram e influenciaram o desenho e a cor do bairro - a princípio imigrantes italianos, judeus de toda parte, sírio-libaneses, gregos e muitos outros em menor escala do leste europeu; atualmente, cederam espaço à comunidades coreana, chinesa e hispano-americana. Cada qual contribuiu com suas heranças culturais, edificando templos e escolas conforme suas religiões.

Caminhar por dentro do bairro é conviver com a retidão de um judeu ortodoxo, passar em frente a uma cantina barulhenta de gregos, sentir o aroma das burekas búlgaras (tipo de rosquinhas folhadas), ouvir a conversa cantante e indecifrável entre orientais. E em cada uma destas esquinas há uma ploriferação de símbolos e imagens como que reafirmassem a presença de cada etnia. Há um enfrentamento velado.

Quando as lojas de vestuários se fecham, a rua se esvazia, descem as portas chapeadas, tornando quadras em blocos únicos, como uma grande barreira. Os prostíbulos se afastaram, mas ainda se pode ver o movimento noturno mais adiante. Vê-se ao longe a sinagoga azul e verticalizada, uma das muitas. Do outro lado, a Congregação protestante - quase cercada por uma boa porção de Paróquias católicas. Todas recebem seus fiéis, e em especial, em datas festivas e santas. Os transeuntes são outros, laicos ou clérigos, com outras vestes, e em outro ritmo de andar.

Apesar da miscelânia de lojas, há uma sobriedade evidente no ar. Cores sóbrias e escuras que demonstram uma necessidade a prestar dignidade ao lugar, mas também à praticidade e à manutenção necessárias. São padrões contidos em que somente um desatento arrisca um destaque no padrão cromático. Ali a cor parece ter uma denotação moral. 

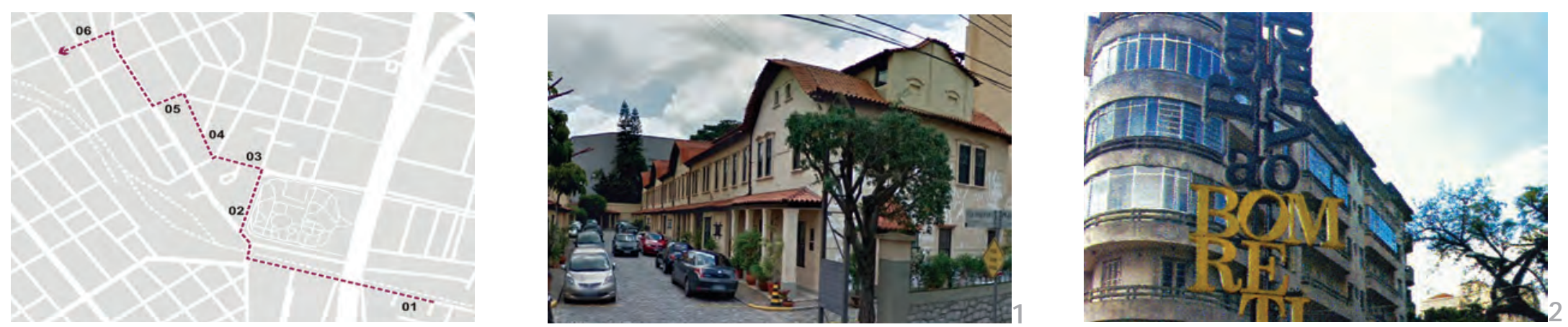

1. Rua Mauá

(Vila dos Ingleses)

2. Esquina Rua Prates $x$

Rua J osé Pa ulino

3. Rua Prates $x$

Rua Ribeiro de Lima

4. Esquina Rua da Graça x

Rua Luba vitch

(Sinagoga -

Congregação Israelita)

5. Rua J osé Pa ulino $x$

Rua Silva Pinto

(comércio de vestuánio geral)

6. Rua Tenente Pena x Rua dos Italianos

(detalhe: portão;

Museu Emílio Ribas)
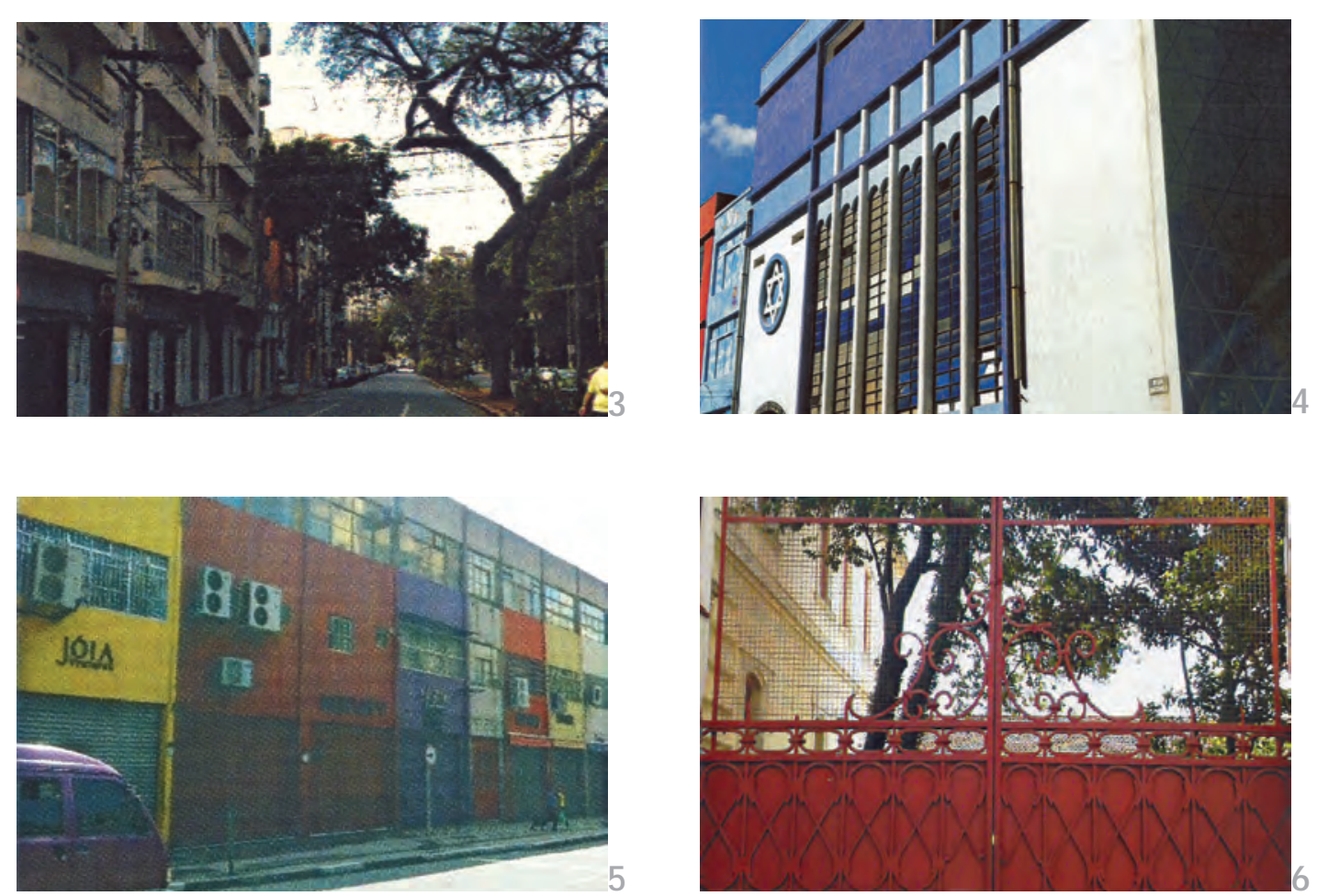


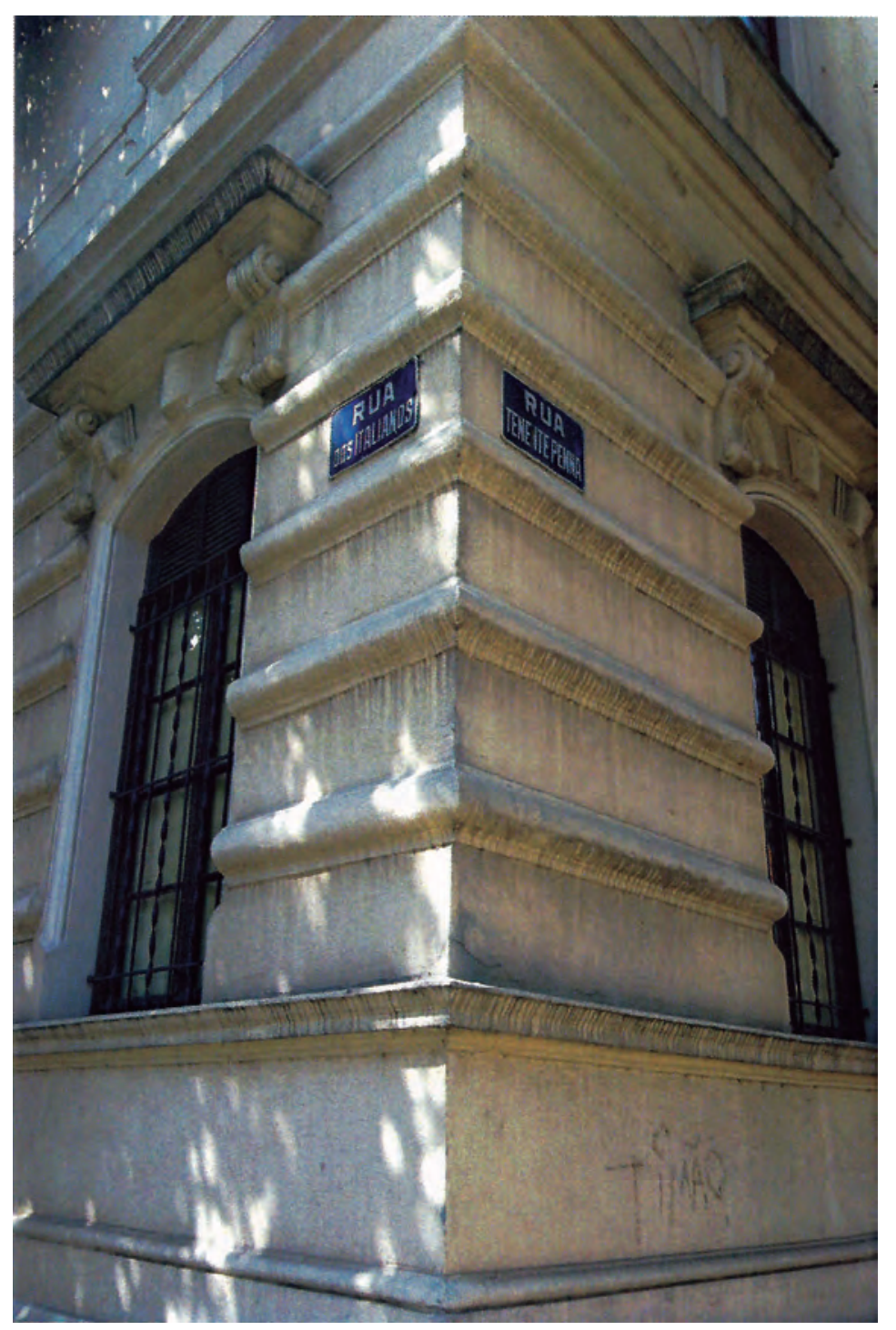




\section{UZ}

SÃo CAETANO

A Luz é um ba irro do distrito do Bom Retiro que nasceu como bairro fabril e operário, ligado à industrialização e à vinda de mão-de-obra imigrante -, em contraste ao seu vizinho,

Campos Elísios - bairro nobre dasmansões neoclássicas e alamedas.

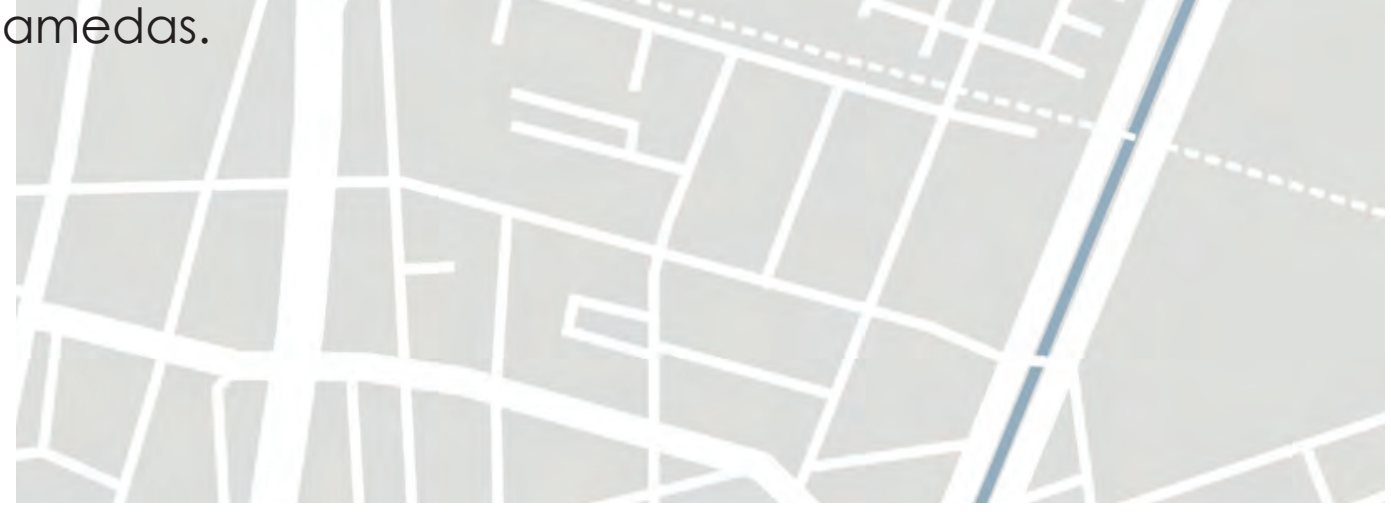


As estações da Luz e da Júlio Prestes, dia e noite, parecem um vespeiro imenso, com chegadas e partidas de gente de todo lugar - muitos se dirigindo ao intenso comércio local, para o atacado da Rua José Paulino ou o varejo da Rua São Caetano - rua das noivas, cujas consortes são literalmente puxadas para dentro das lojas por vendedoras estridentes.

A passagem do trem corta a cidade. E juntamente ao viaduto por sobre a Avenida Tiradentes, permite uma abertura no tecido urbano, proporcionado um atraente campo visual que permite avistar-se a cidade em direção Norte-Sul. Cercam-nos, os altos prédios Institucionais - cinzas ou brancos, as Paróquias, a Torre do Relógio da Estação da Luz, em tijolo aparente e um leve creme amarelado que faz par com outros imóveis do entorno.

O Parque da Luz foi palco de tempos fartos para se passear com glamour, foi descrito em inúmeros romances de época em que vadiar pelas ruas era motivo de prisão, passou por está gio inglório pelo que tenta reverter. Há ali no jardim da Luz esculturas coloridas e chamativas expostas da Pinacoteca, um café charmoso no meio da vegetação com ares refinados.

A Rua das noivas é o avesso. Congestionada de automóveis e pessoas com sacolas, numa via estreita com calçadas que disputam espaço com os ambulantes. As casas de operários grudadas viraram lojas, há vielas que conduzem para o meio das quadras e somente dentro de seus pátios o burburinho é menor. Tudo é colorido como que para distinguir-se do tanto branco de vestidos de noiva. As cores são tantas e necessárias, para a identidade de um estabelecimento que queira ser lembrado após uma caminhada extenuante. 

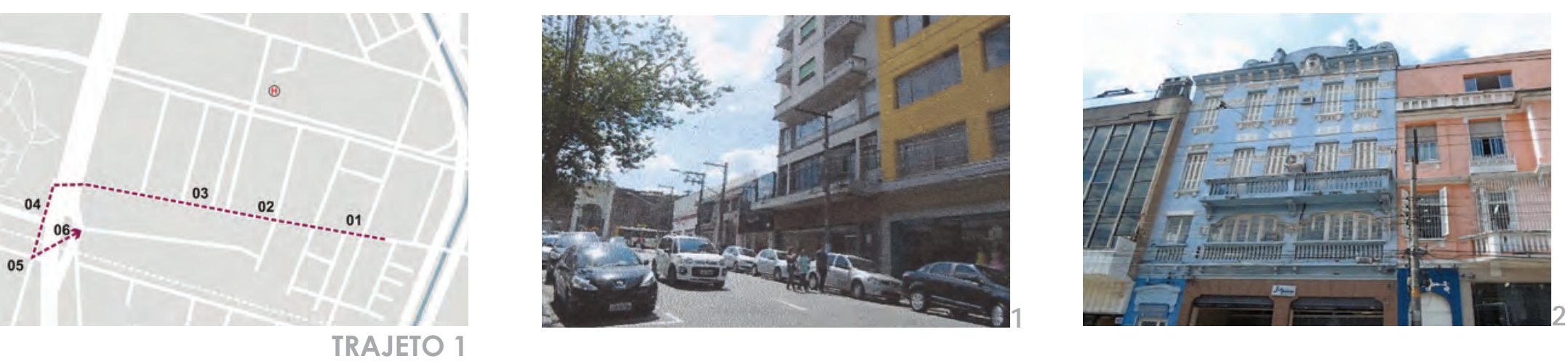

1. Rua São Caetano x Rua da Cantareira

2. Rua São Ca etano (Rua das Noivas)

3. Rua São Ca etano x Rua Dom Antônio de Melo (comércio, serviço, habitações)

4. Praça da Luz (estação ferroviária da Luz)

5. Rua Mauá

6. Passa rela sobre Avenida Tiradentes

(vista da Rua Brigadeiro Tobias)
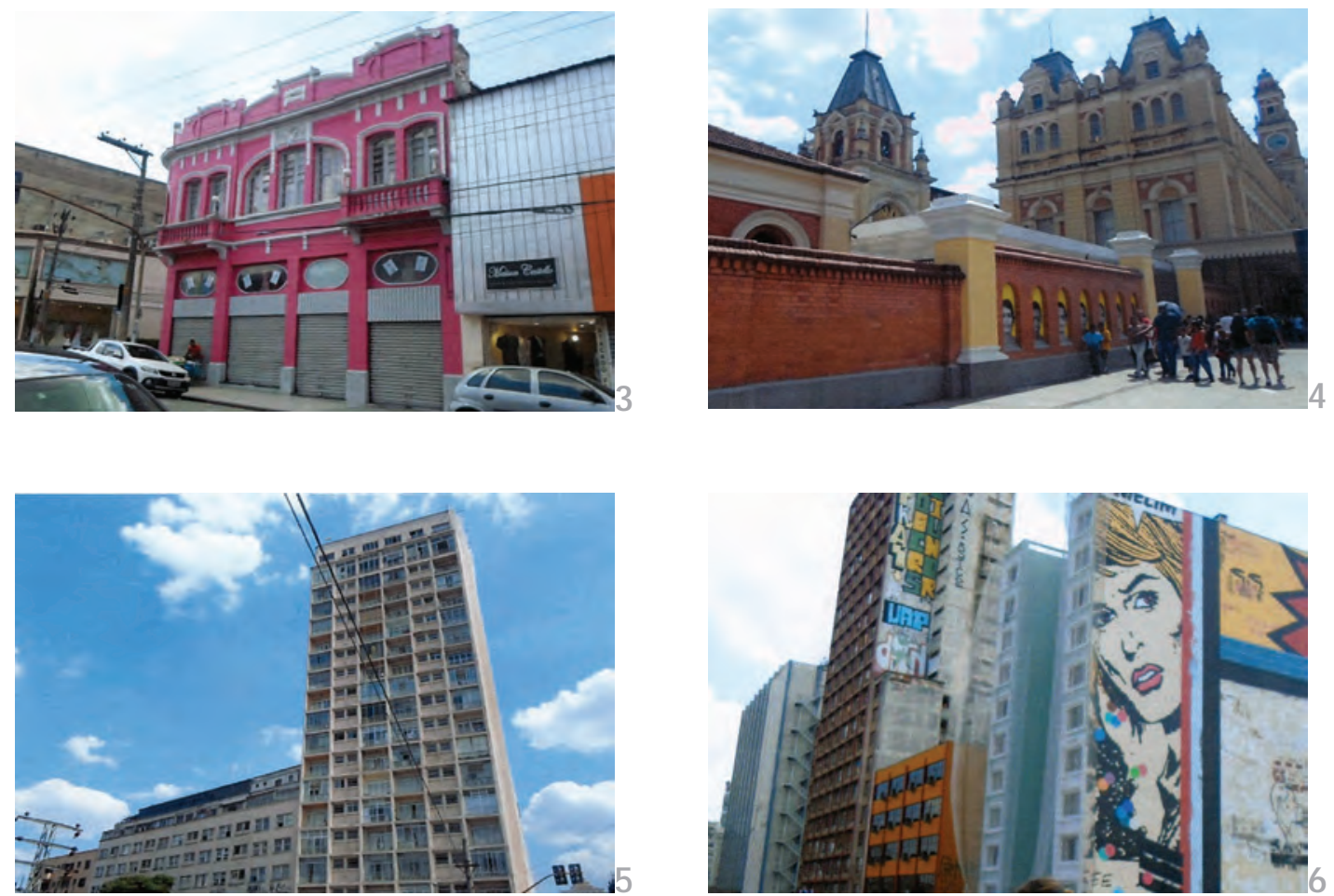


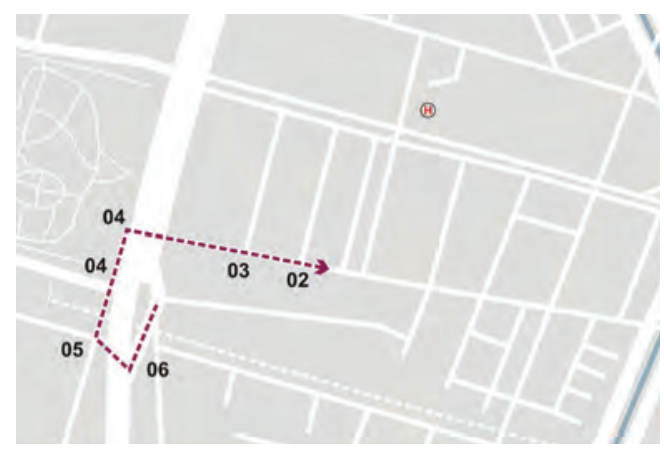

TRAJETO 2

1. Passa rela sobre Avenida Tiradentes

(vista da avenida)

2. Avenida Tiradentes $x$ Rua Mauá

(estação ferroviária da Luz)

3. Avenida Tiradentes

4. Avenida Tiradentes (Pina coteca do Esta do)

5. Rua São Caetano $x$ Rua Dutra Rodrigues

6. Rua São Ca etano (Rua das Noivas)
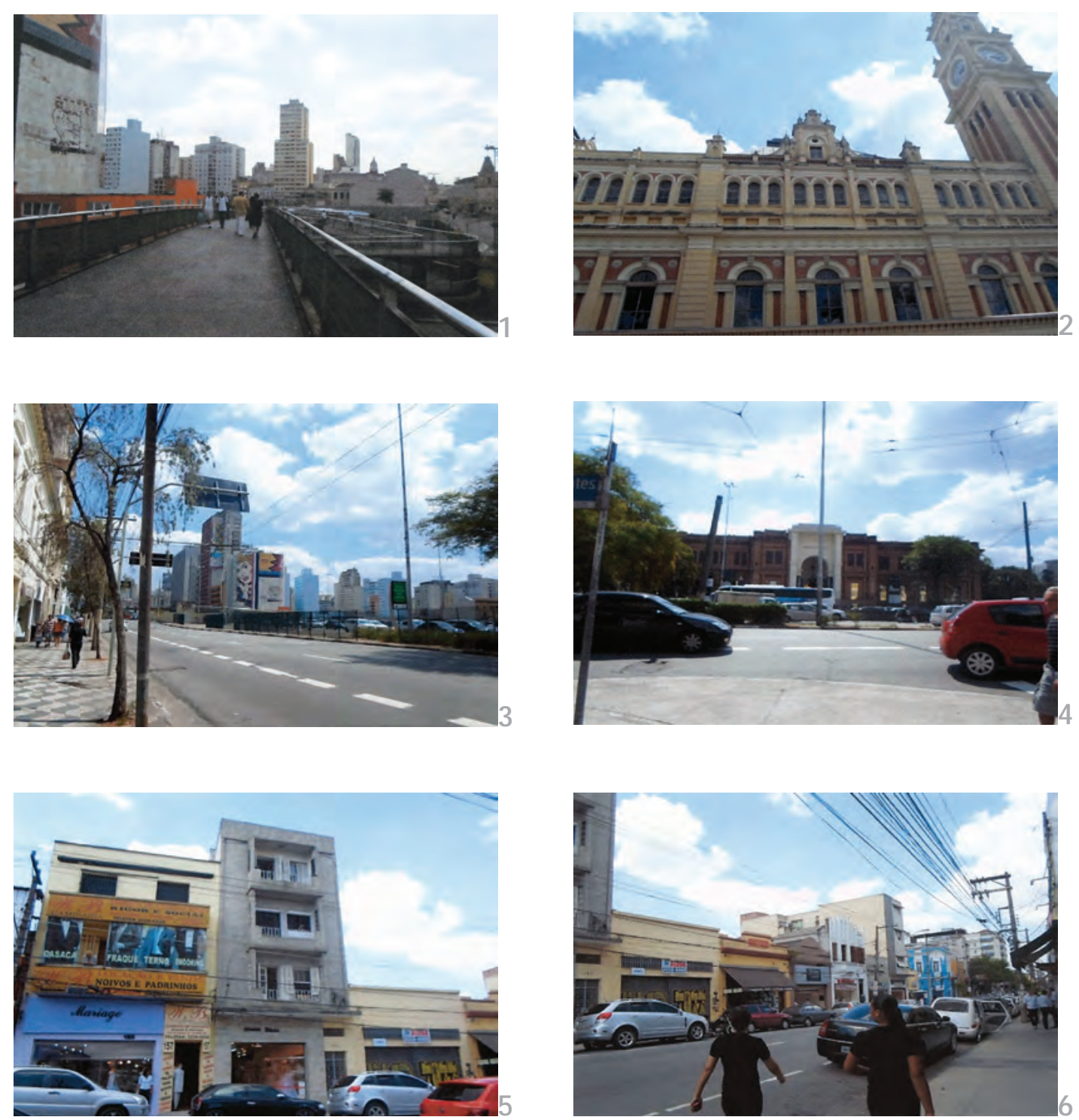


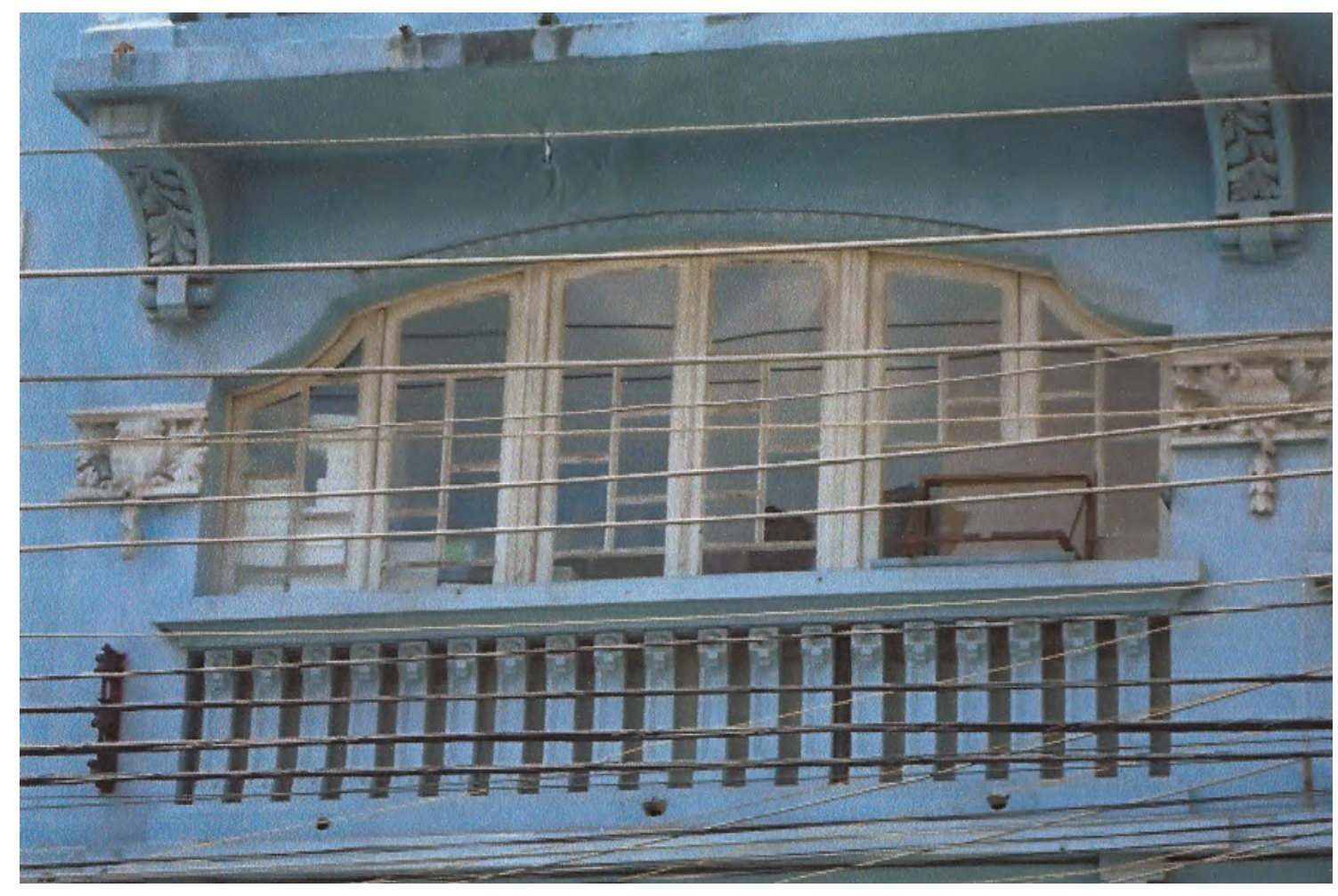




\section{CAMPOS EÍSEOS}

Considerado bairro nobre e elegante, no distrito de Santa Cecília, na região Central, onde se fixaram no loteamento teuto-suiço de vastos terrenos, vários dos a ntigos fazendeiros do café e, ma is ta rde, ta mbém recebeu a sede do Govemo do Esta do de São Paulo.
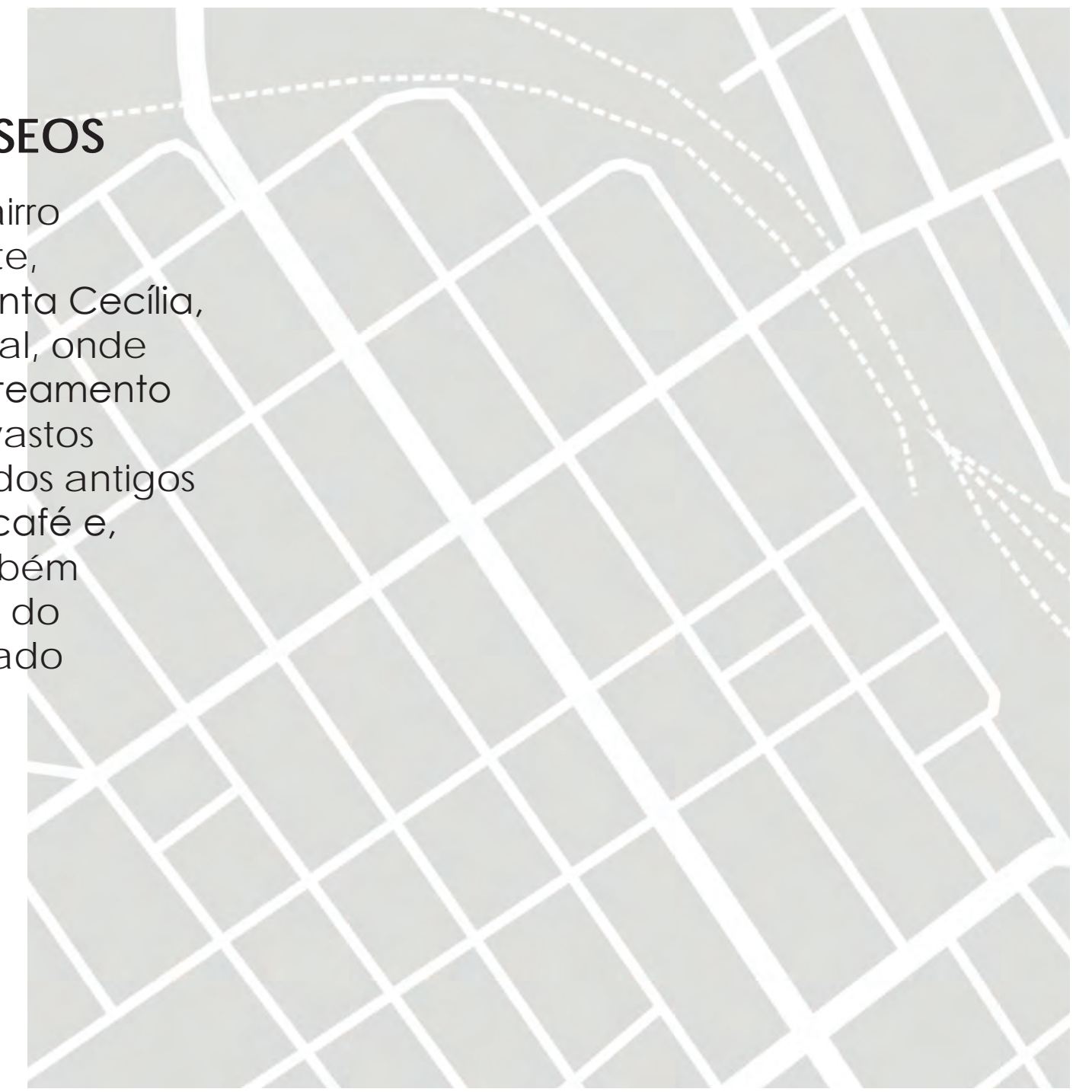
Podem-se ver algumas mansões que sobreviveram ao declínio do bairro, com a queda dos barões do café e a transferência da sede de governo. Pela iniciativa privada tentam permanecer no local, ocupando e reformando esses imóveis. A iniciativa pública é tímida.

Ainda muitas edificações tornaram-se cortiços, pensões ou moradias coletivas precárias, áreas próximas aos trilhos foram invadidas tornando-se favelas e a desativação da estação rodoviária - com sua cobertura multicolorida de policarbonato -, mantiveram os desocupados e os viciados à sua volta.

A área próxima da Cracolândia, com a prostituição, a marginalidade e o uso de drogas, é feia, desagradável - não pelo conceito da promiscuidade ou pelo medo que paira no ar, mas por tudo parecer passagem e distanciamento. Muito cinza e em completo desleixo.

Avista-se também pelo bairro os catadores de papelão - moradores de rua com seus carrinhos e cães, caminham em direção à Barra Funda, onde está a oficina de reciclagem de papel Boracéa.

O bairro tem uma configuração interessante, com diferentes marcos, ângulos generosos e composições cromátic as muito harmônic as que são entrec orta das pelos eventua is transeuntes. Mas não há nem convivência, nem permanência - nem mesmo os pixadores se aventuram pelos muitos muros existentes. 

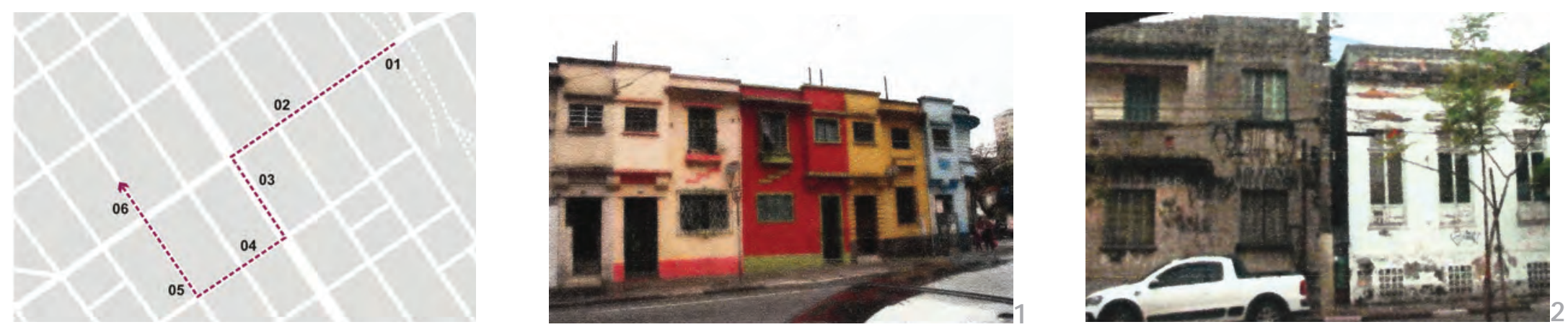

1. Alameda Nothmann (altura da Rua Silva Pinto)

2. Alameda Nothmann $x$ Alameda de Piracicaba

3. Avenida Rio Branco $x$ Alameda Nothmann

4. Alameda Glete

5. Rua Conselheiro Nébias

6. Rua Conselheiro Nébias (detalhe de piso de palacete)
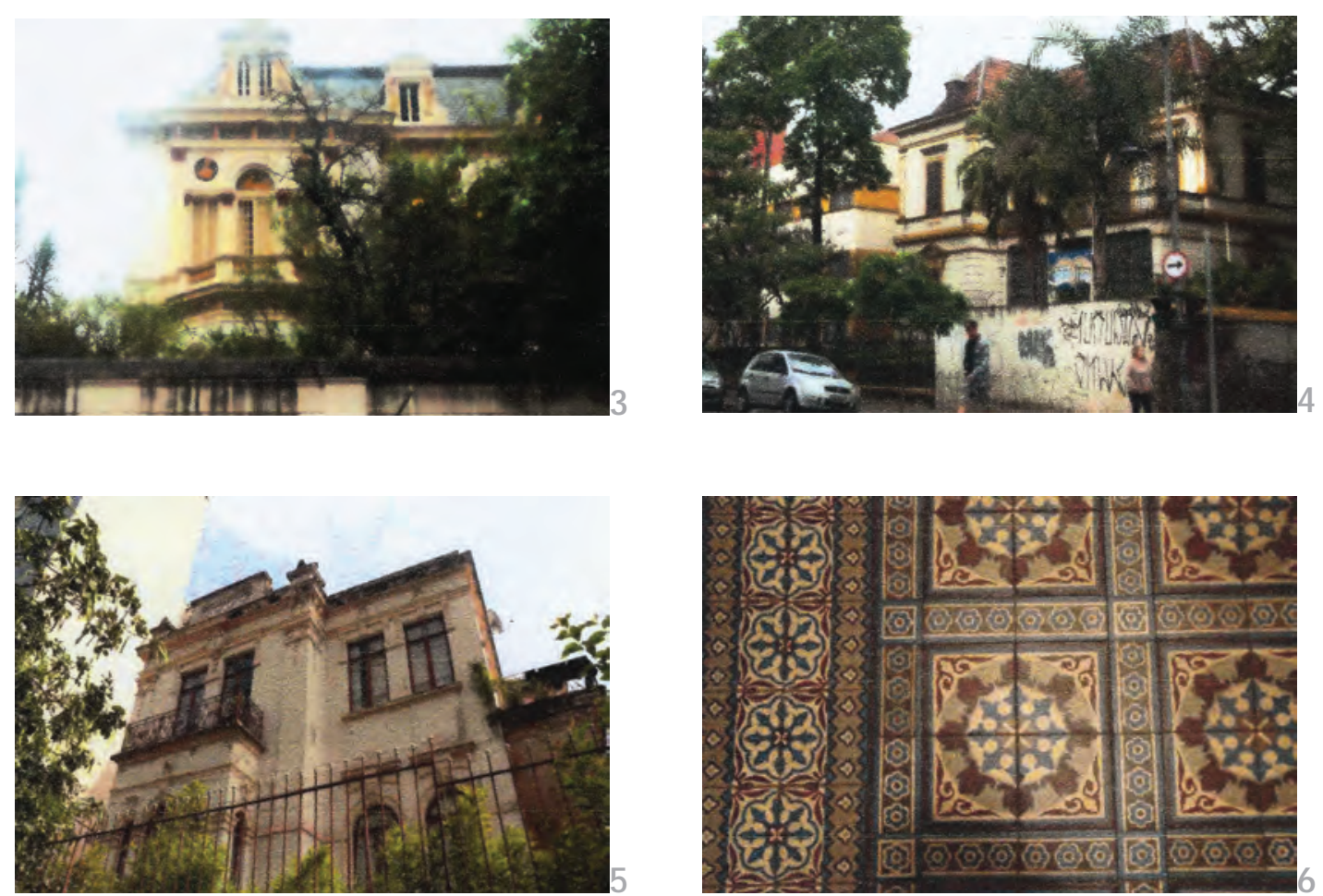


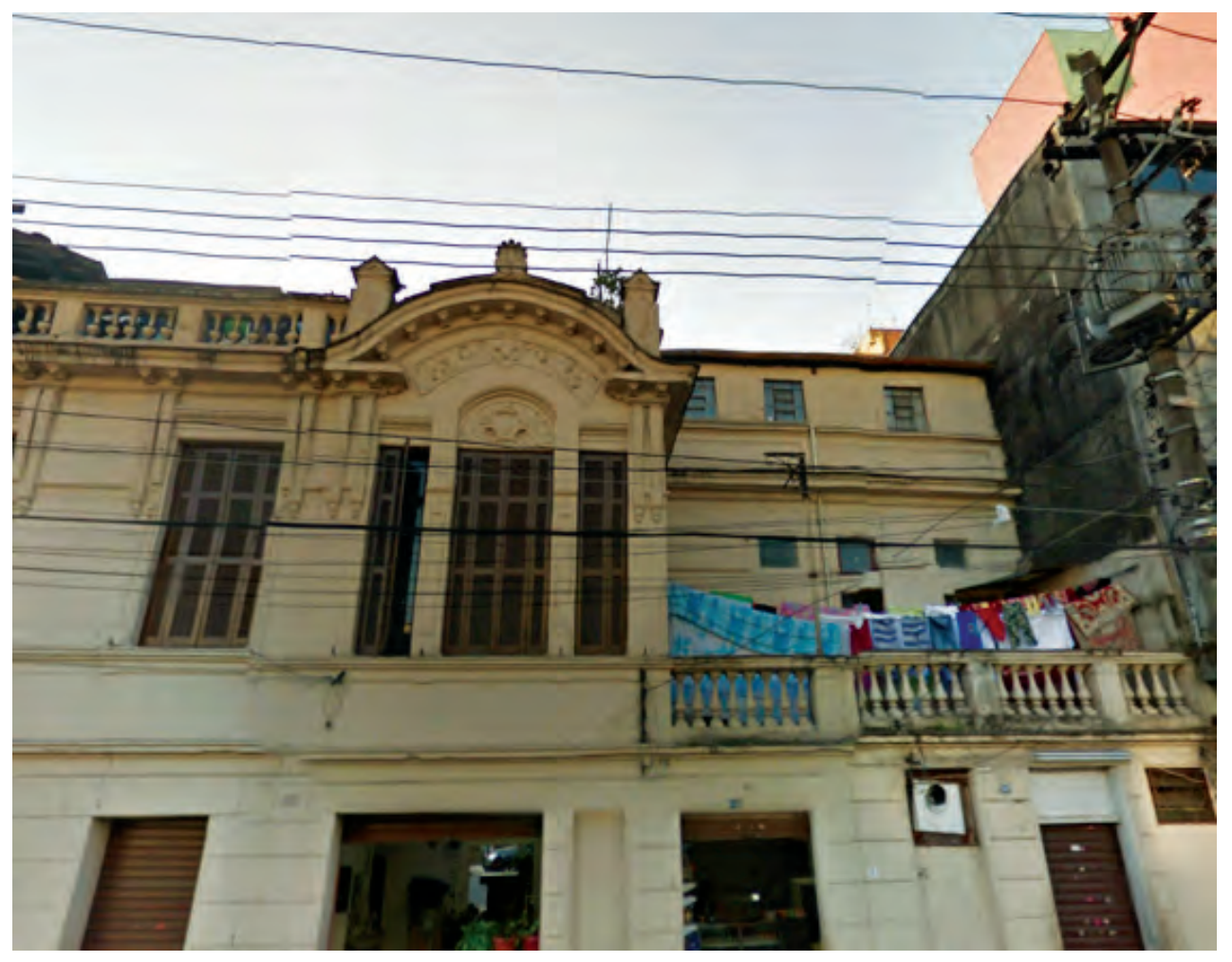




\section{UBERDADE}

Antes um reduto quase que exc lusivo de imigrantes japoneses, hoje turistase moradores vindos de outras etniase de outras regiões do país proliferam.

Pela proximidade física a Sé e ao centro velho, o bairro tomou-se muito voltado ao comércio e ao serviço, mas em suas ladeiras se observa as moradias -

algumas típicas.

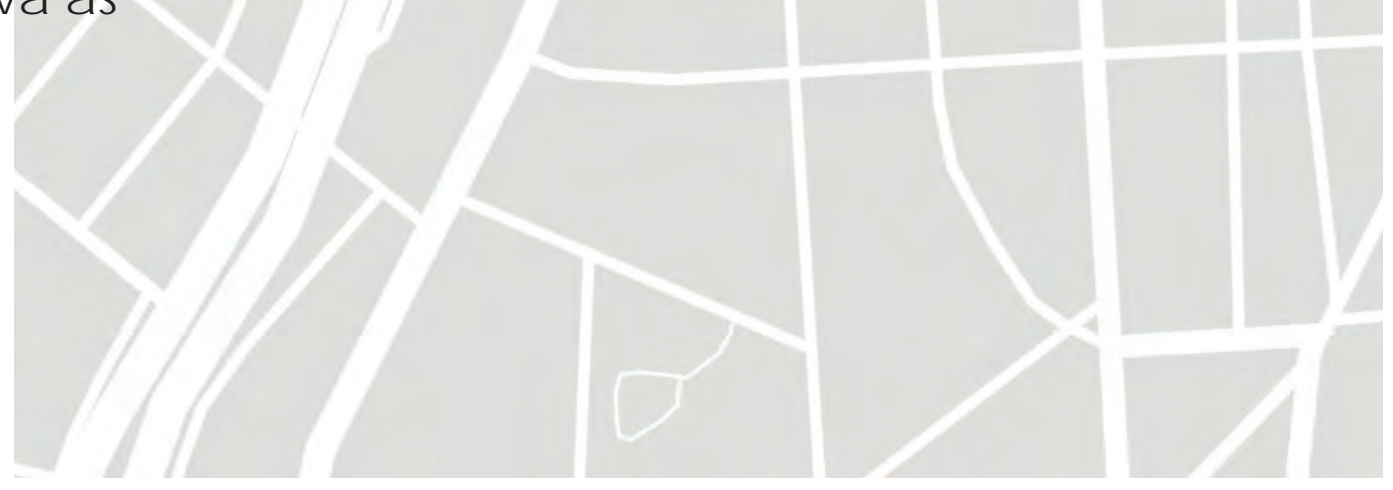


Há uma dualidade interessante da cultura oriental; em particular a japonesa, onde convivem o sóbrio, a retidão (denomina do wabi sabi) e o escadaloso, o vibrante (denominado hade).

A cor mais presente no bairro é o vermelho, da própria bandeira do Japão e dos tori - pórticos xintoístas. Mas o mesmo vermelho passa a ser vibrante se posto em composições chamativas, destinadas aos festivais, às vestimentas típicas - kimono, voltados ao verão e a juventude; em contrapartida, aparece nos mais diferentes padrões elegantes, das mesmas vestimentas voltadas a cerimonias tradicionais, ao inverno, à velhice.

Fica patente que a cor importa menos se isolada - mas sua posição junto a outras ou sua proporção. Esta percepção ao longo do passeio por suas ruas, que ora as cores contrastam, ora atenuam a paisagem, em meio a tantas pessoas que circulam nas imediações a partir da Praça da Liberdade e descendo as ladeiras do bairro.

O tori é um elemento de proteção e representa a divisão entre o mundo comum e o divino, espiritual - com suas peças em madeira encaixada, pilares representam alicerces que sustentam o céu, e as vigas, a terra. O mesmo sentimento de passagem acontece em vários lugares ali - nas entradas dos estabelecimentos, seja de uma loja de miudezas ou de um restaurante típico - passando-se pela porta fica para trás o mundano e o embaralhamento dos sentidos. Há um gosto comum pelos tons sóbrios em combinações de nuances análogas.

Andar pelo bairro sem adentrar, só se pode ver a casca, a superfície do estereótipo, do chamativo para as festividades ao gosto ocidental. Há nos detalhes informações sutis e sublineares que olhos atentos devem buscar. É o momento de sentar-se e perceber as relações das pessoas, dos espaços, das cores. 

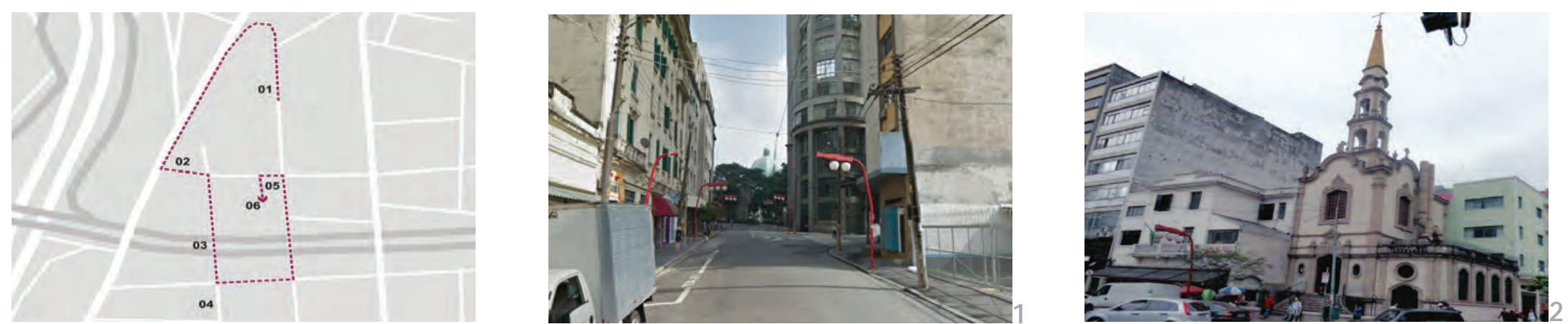

1. Rua da Glória

2. Avenida da Liberdade $x$ Praça da Liberdade (Igreja das Almas - Capela da Sta. Cruz dos Enforcados)

3. Viaduto Avenida Cidade de Osaka

(vista da Av. Radial Leste-Oeste)

4. Rua Galvão Bueno

5. Rua dos Estudantes (detalhe de entrada de típico restaura nte/ residência)

6. Rua dos Aflitos

(Igreja dos Aflitos/das Velas)
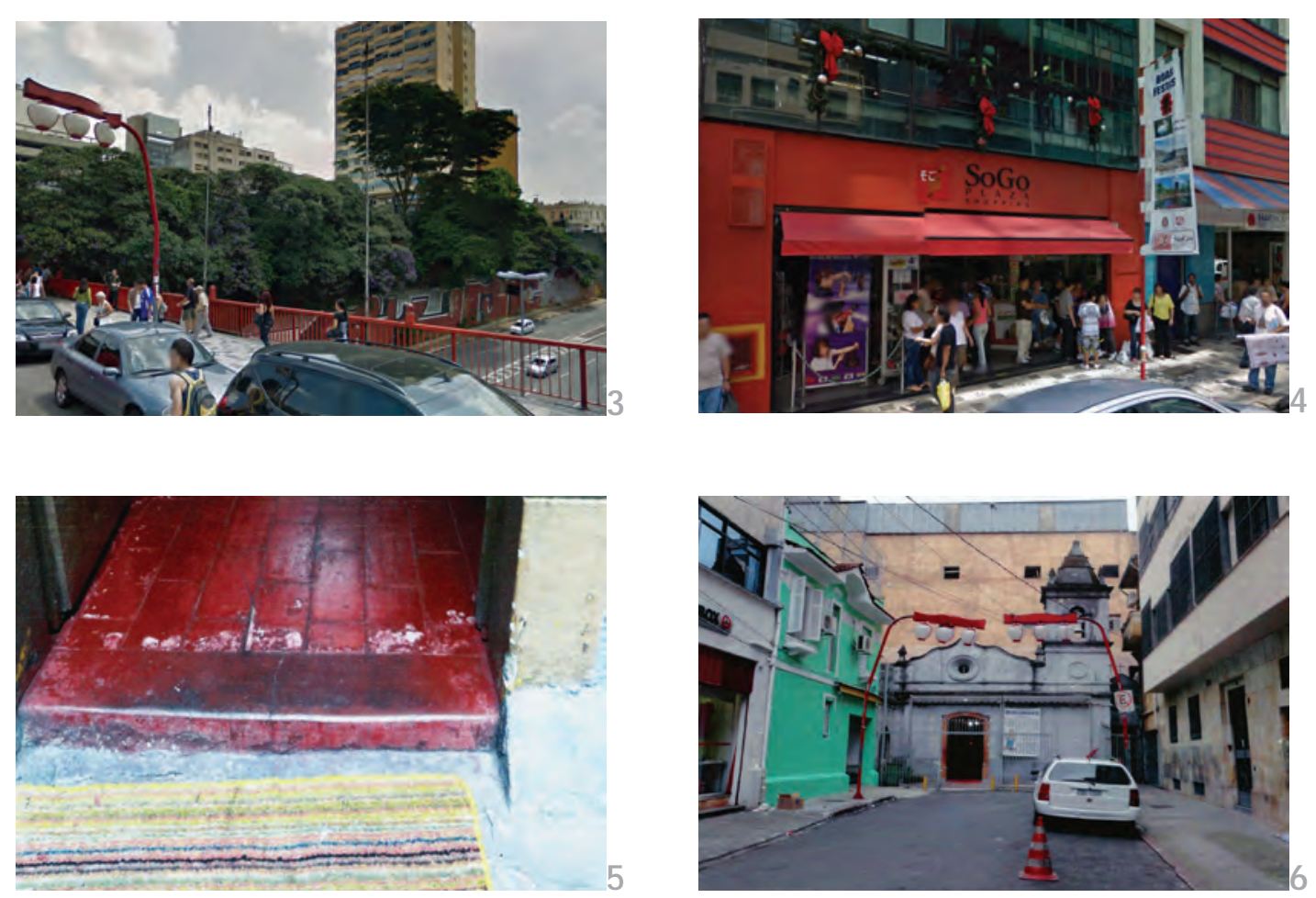


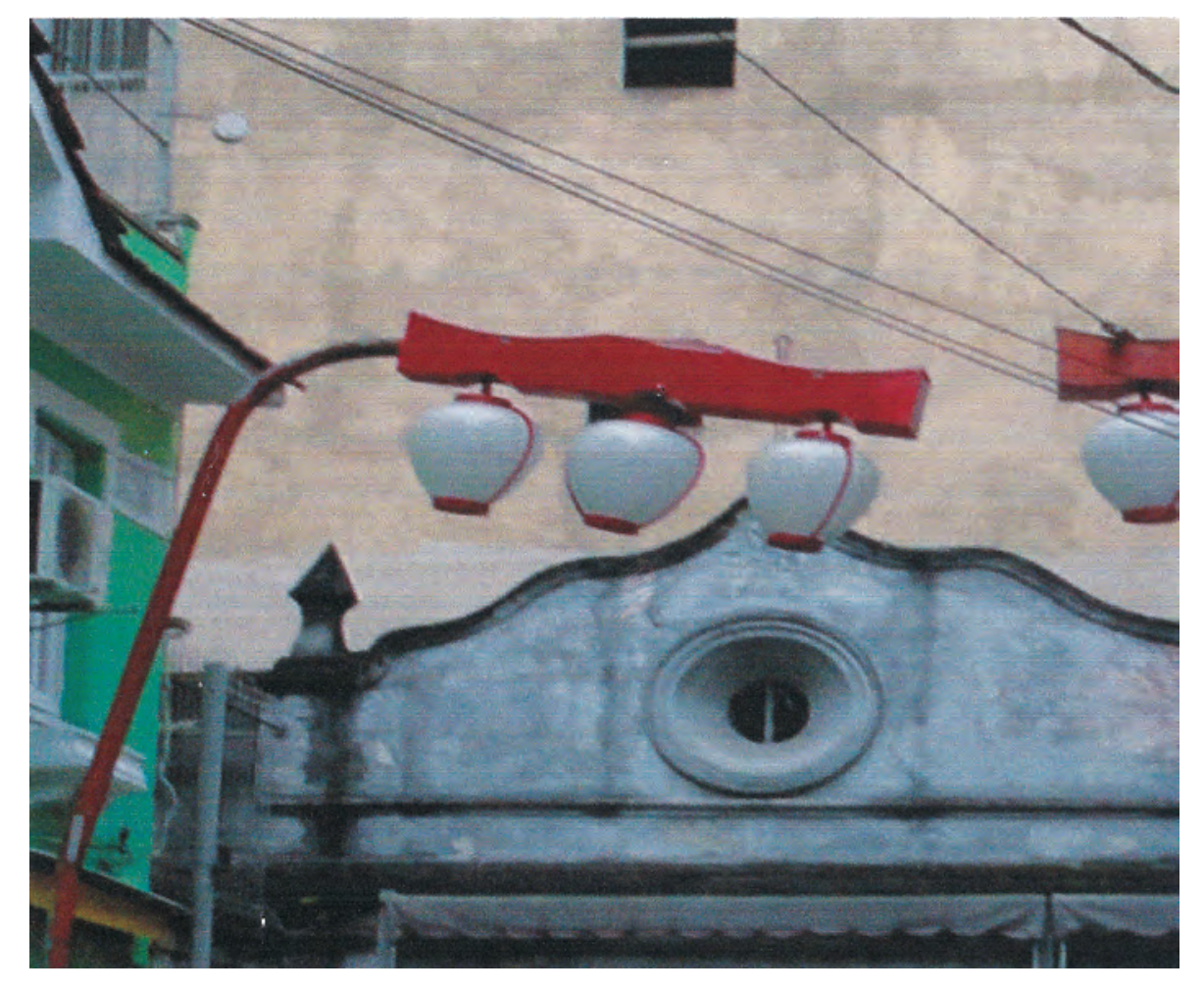




\section{CENTRO}

\section{REPÚBLICA / ANHANGABAÚ}

O centro históric o da cida de está contido oficialmente entre os distritos República e Sé.

Eé onde se melhor observa como a cidade se fragmenta não somente em funções, mas nos diversos períodos que foram necessários para construí-la, e que estão representados ao longo dos lougradouros. 
A escolha por esta parte central da cidade segue o critério da vasta população que percorre a pé, entre as estações de metrô, e ainda se utiliza da diversidade do comércio e serviços. Há também edifícios residenciais com os térreos de uso público ou de comércio, várias galerias que a tra vessa m as qua drasgenerosas, e a inda becose rua sestreitas perdidasneste meio, que somente um atento olhar pode registrar.

Os edifícios quase sempre colados lado-a-lado, alternam os gabaritos, proporcionando a entrada de luz solar recortada, que modifica também a percepção das cores das edificações e do próprio arruamento. O cinza prevalece, mas é rico em nuances de degradês.

A escolha dos materiais de revestimento também influencia na sensação visual, pela opacidade de certos vidros, no fosco das pastilhas cerâmicas, a mica do reboco antigo, no olhar velado dos cobogós, no azulejo encomendado, no reflexo das pastilhas de vidro, no piso de pedra portuguesa que nos fazem olhar para baixo sempre evitando um deslize. Há ainda muito ferro fundido, a ferrugem que acompanha o tempo e alguns revestimentos de madeira em paineis.

O trajeto total foi subdividido em três partes, conforme algumas peculiaridades únicas ou que se repetem em outras ruas do entorno. Iniciou-se pelo percuso da Ladeira da Memória - que abriga uma estação de Metrô e se abre em direção do Anhangabaú. Abriga árvore imensa e rara, uma aroeira branca, com fonte e escadaria escultural além do Obelisco do Piques, que era o ponto de partida dos caminhos para fora da cidade. 
Muro, degraus e bancosem pedra, que contrasta m com o painel de azulejos portugueses, em azul e branco. O revestimento traduz a mesma rigidez do piso, necessária ao intenso trânsito de pedestres e que não sucumbiu ao intenso uso.

O segundo percurso vai das proximidades da Ladeira da Memória, atravessando pela Rua 7 de Abril, até a Praça da República. Rua de trânsito de automóveis e mais estreita do que a paralela Rua Barão de Itapetininga, que atualmente é calçadão, com maior comércio e maior passagem de pessoas. Pela Rua 7 de Abril, em curva leve, é possivel observar melhor os edifícios que se sobrepõem, ora avançam com suas marquises modernistas fornecendo abrigo, ora se recolhem do meio fio e se abrem em galerias comerciais.

O comércio quase sempre adota no pavimento térreo uma intensa cor própria à atração, enquanto o padrão dos pavimentos superiores se mantem sóbrios, neutros e elegantes. A cor pode ser verificada quase sempre em detalhes destes edifícios antigos: nas portas de entrada, no revestimento do térreo, em um painel de mosaicos — em uma composição discreta se comparada à escala do lugar.

Por último percurso, optou-se por observar as Avenidas Ipiranga, da Consolação e São Luís, porém caminhar por entre os prédios em vielas estreitas e passagem de pedestres. No caso, por entre o Edifício Terraço Itália e Copan - que pela sinuosidade permite uma descoberta de percuso que acontece paula tinamente e, com isto, a cordo local vai assumindo nuances interessantes ao ponto de parecerem diferentes, contudo tratando-se da mesma cor. 


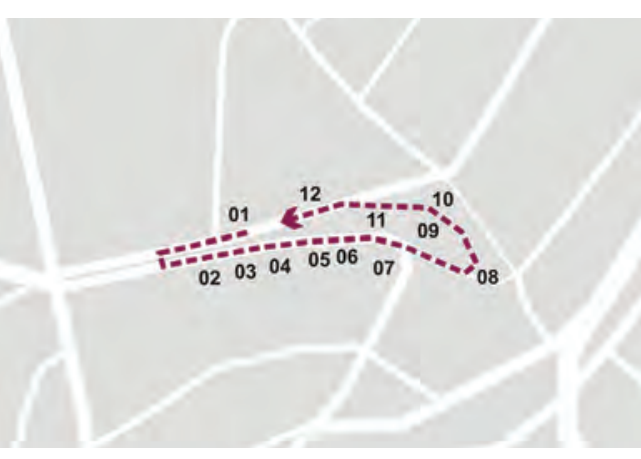

TRAJETO

1. Rua Cel. Xavier de Toleto (próximo à Biblioteca Municipal)

2. Rua Quirino de Andrade (muro de a mimo)

3. Rua Quirino de Andrade (vista da R. Cel. Xavier de Toledo)

4. Rua Quirino de Andrade (vista para unidade UNESP)

5. Rua Quirino de Andrade (vista da esca da ria - Largo da Memória )

6. Rua Quirino de Andrade
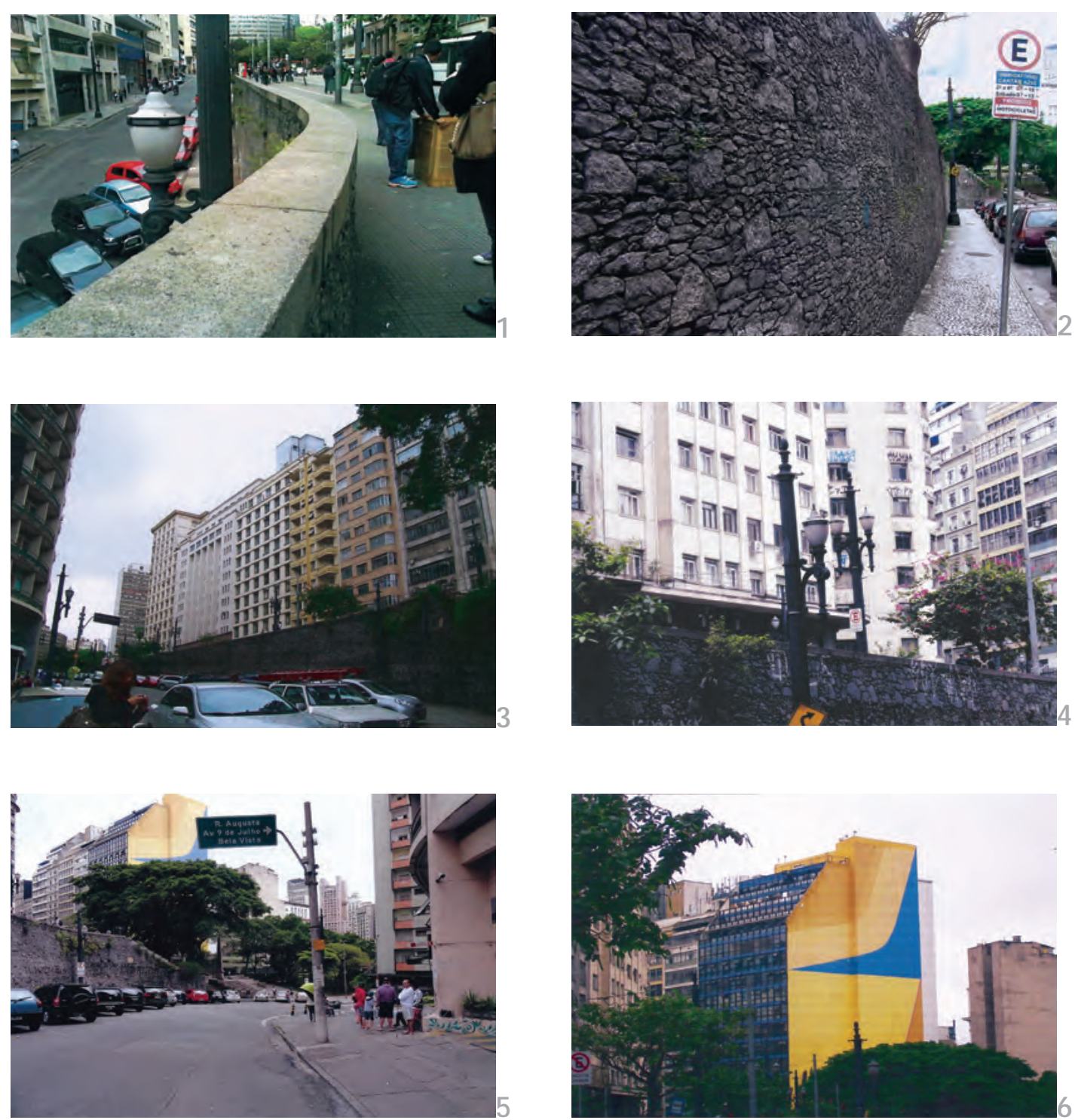

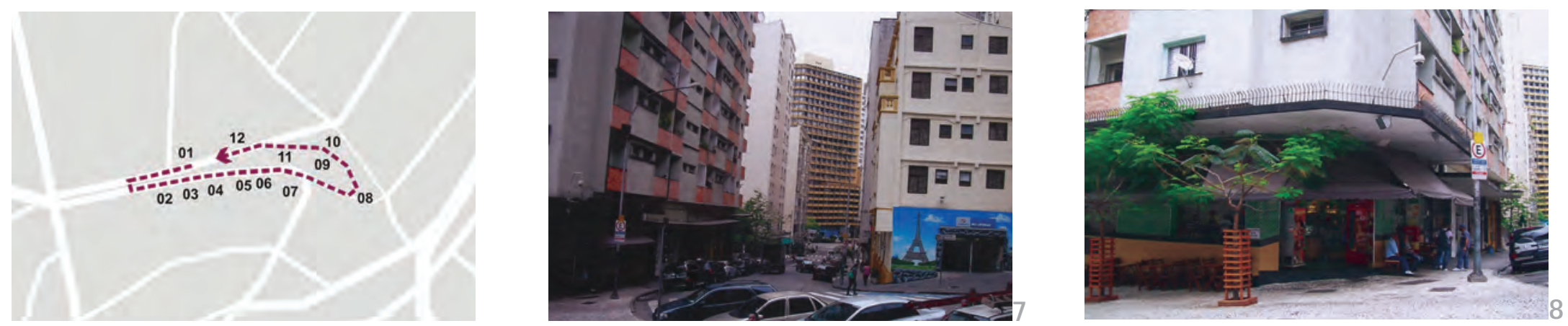

7. Rua Quirino de Andrade x Largo da Ladeira de Memória

8. Rua Quirino de Andrade (esquina)

9. Praça do Obelisco da Ladeira da Memória

10. Praça do Obelisco da Ladeira da Memória (detalhe de revestimento)
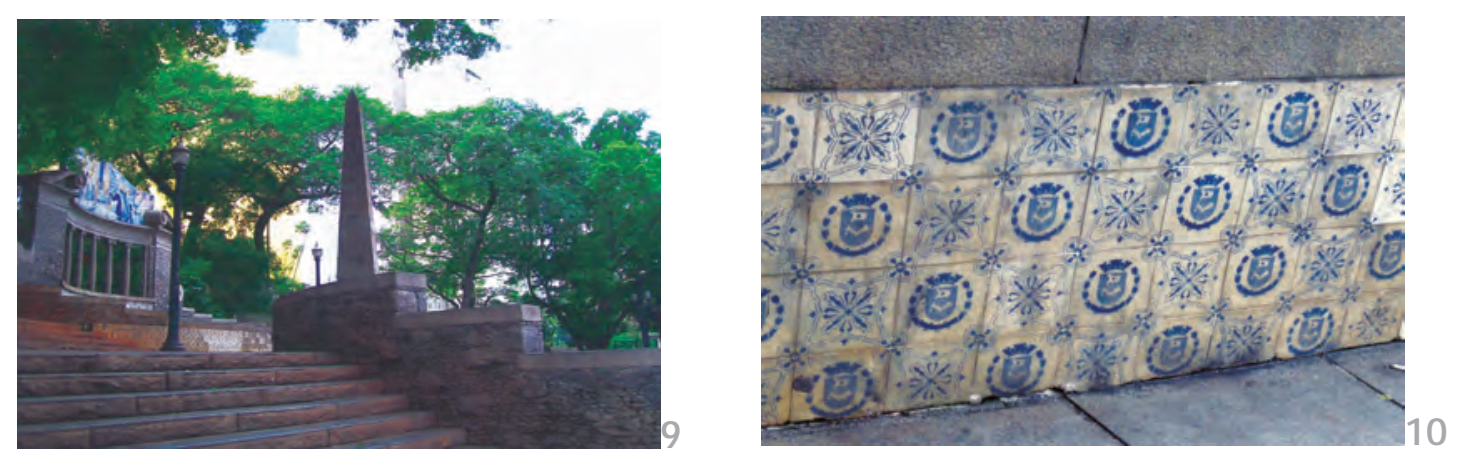

11. Escadaria da Ladeira da Memória (acesso para

Rua Cel. Xavier de Toledol

12. Praça do Obelisco da Ladeira da Memória (vista pela

Rua Cel. Xavier de Toledo)
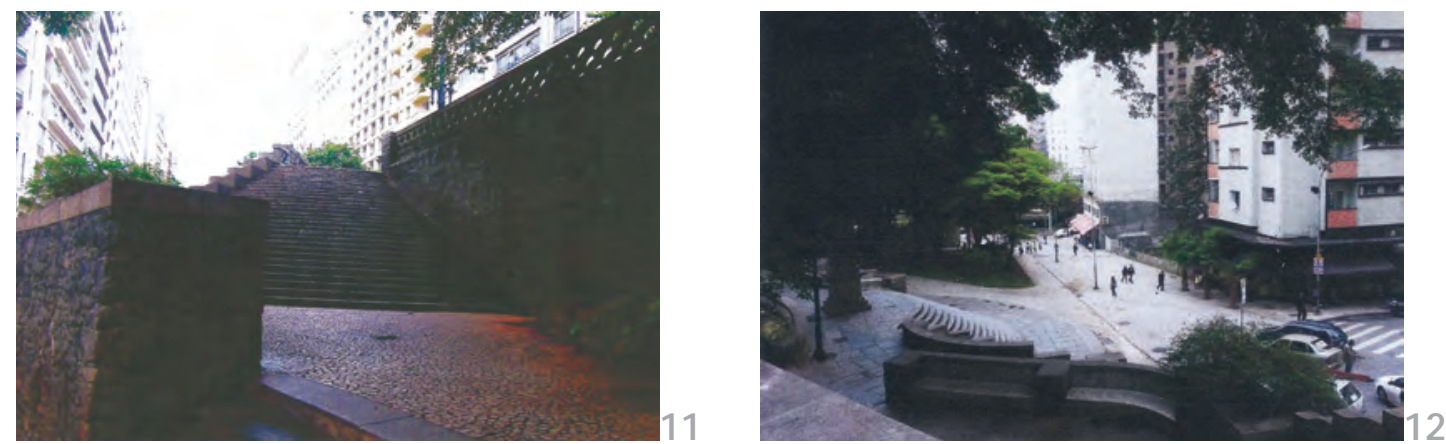

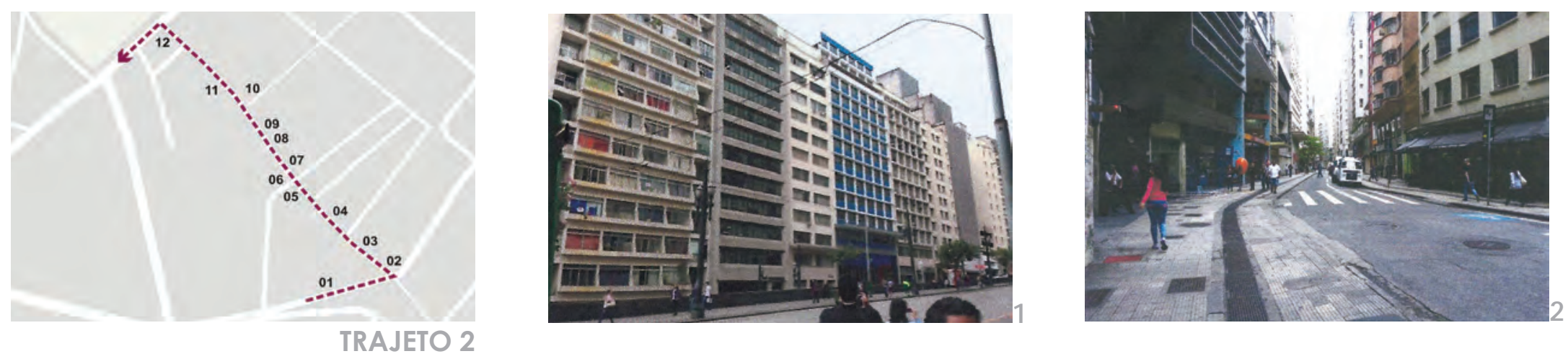

1. Rua Xavier de Toledo

2. Rua Xavier de Toledo $x$ Rua 7 de Abril

3. Rua 7 de Abril

4. Rua 7 de Abril

(vista da Galeria Nova Barão)

5. Rua 7 de Abril $x$ Rua Dom J osé de

Barros - calçadão (detalhe de revestimentos e Galeria Califórnia)

6. Rua 7 de Abril

(vista para Avenida Ipiranga)
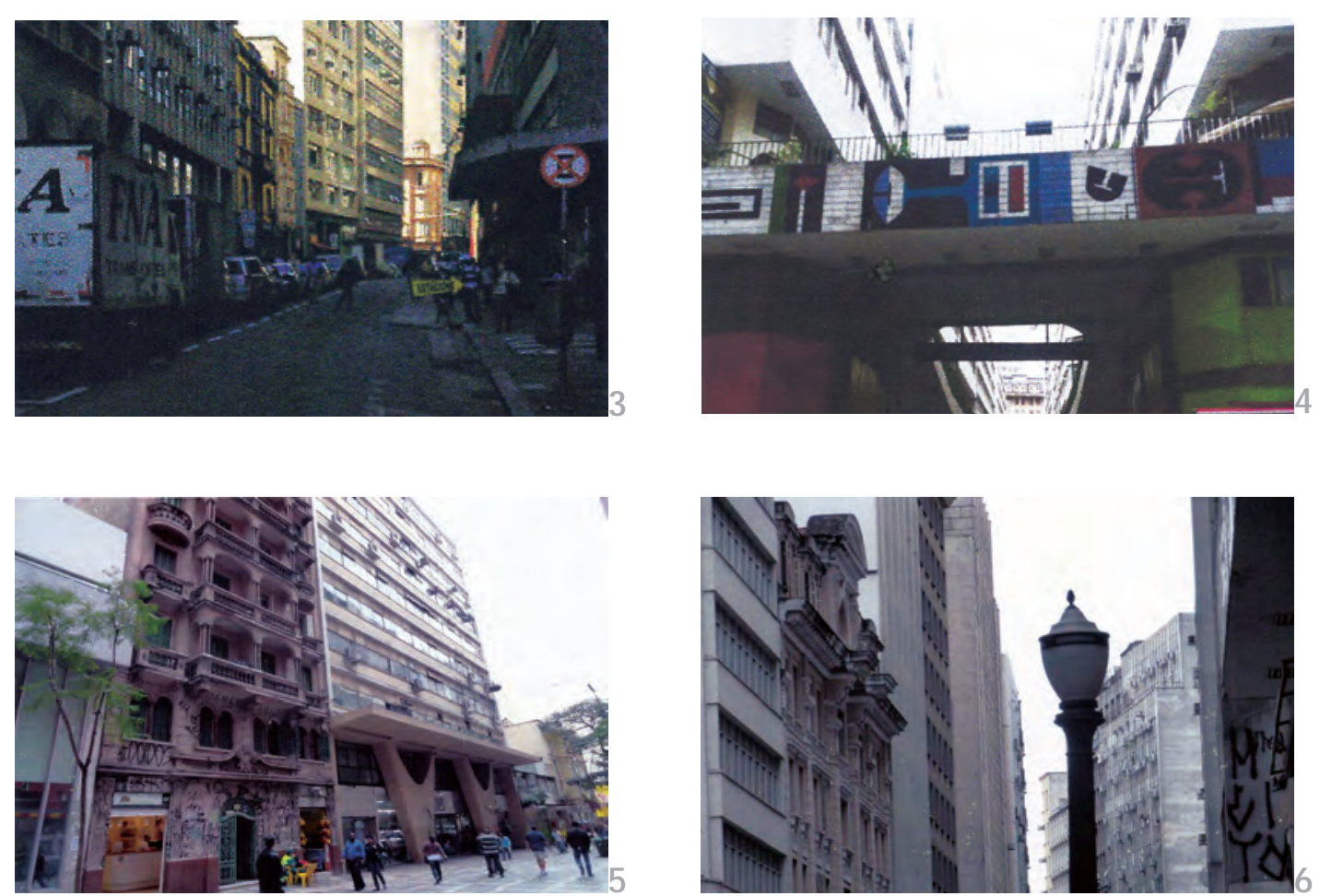

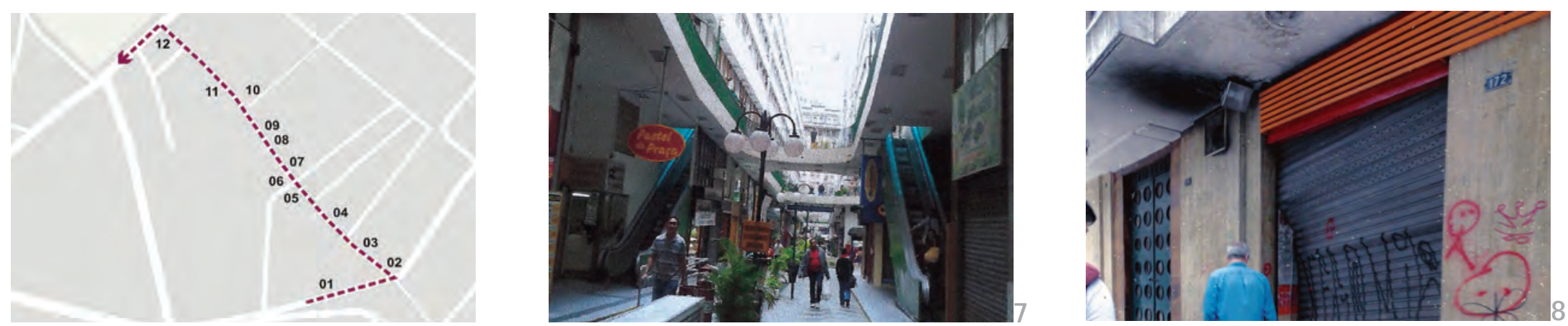

7. Rua 7 de Abril

(entremeio Galeria 7 de Abril)

8. Rua 7 de Abril

(detalhe - fachadas comerciais)

9. Rua 7 de Abril

(detalhe - porta de entrada institucional)

10. Rua 7 de Abril

(detalhe - grelha em piso-ferro)
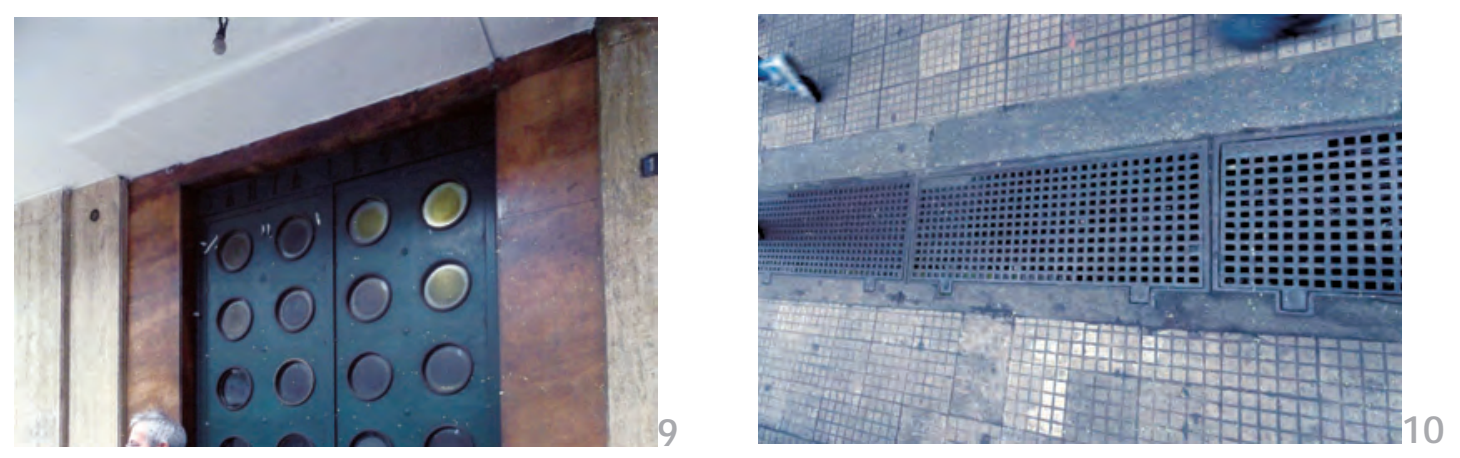

11. Rua 7 de Abril (detalhe - portão de entrada)

12. Rua 7 de Abril

(vista para Avenida São Luís;

detalhe - fachada de habitação)
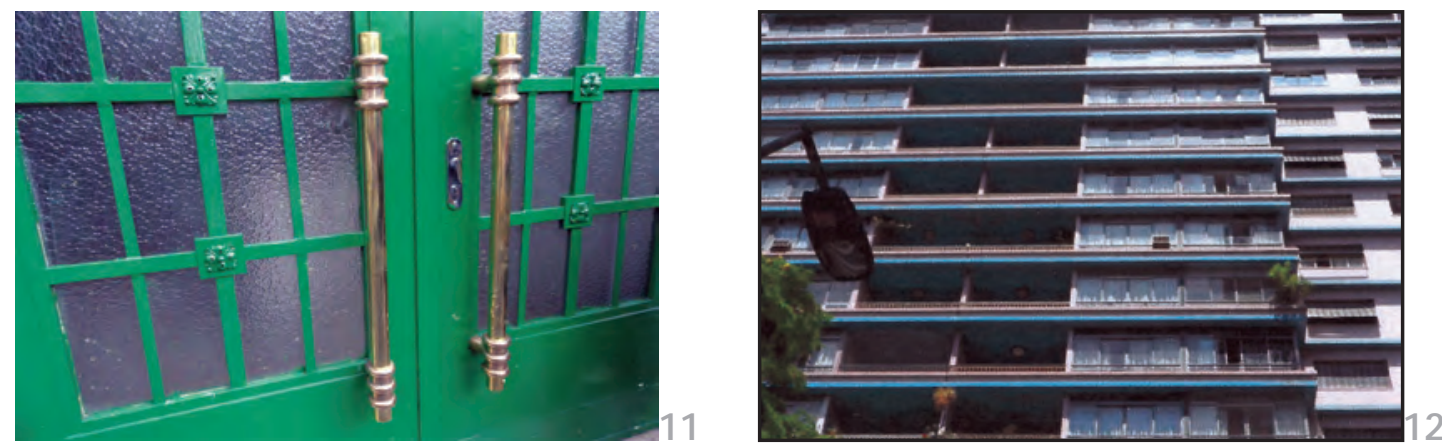

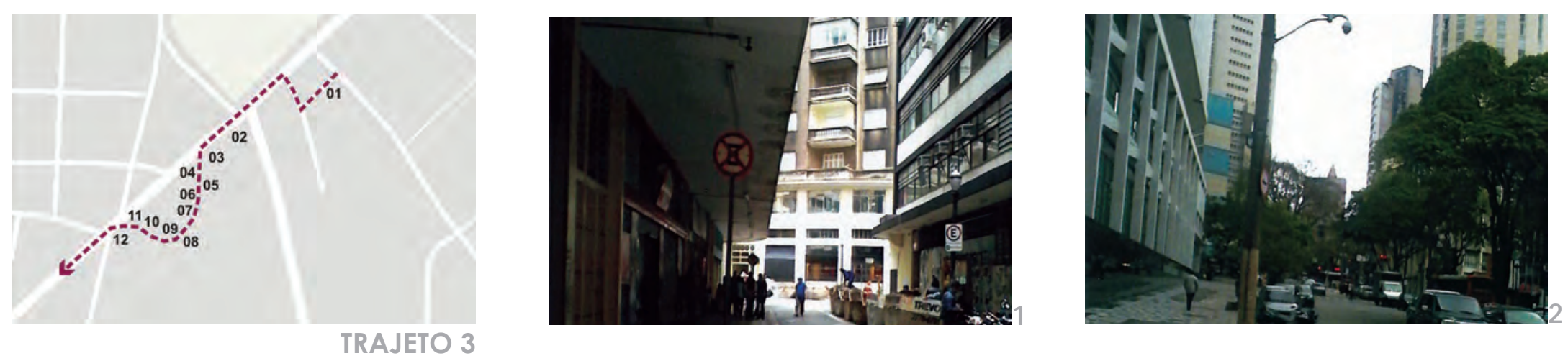

1. Rua Gabus Mendes (vista para Rua Basílio Gama)

2. Avenida Ipiranga $x$ Avenida São Luís

3. Avenida Ipiranga $x$ Rua Major Sertónio (passagem de pedestres entre Ed. Circolo Italiano São Paolo e Terraço Itália x Banco Bradesc o x Copan)

4. Via intema (passagem de pedestres; vista do Copan)

5. Via intema

(detalhe - escadaria helicoidal)

6. Via intema

(vista: entra da da Galeria Copan)
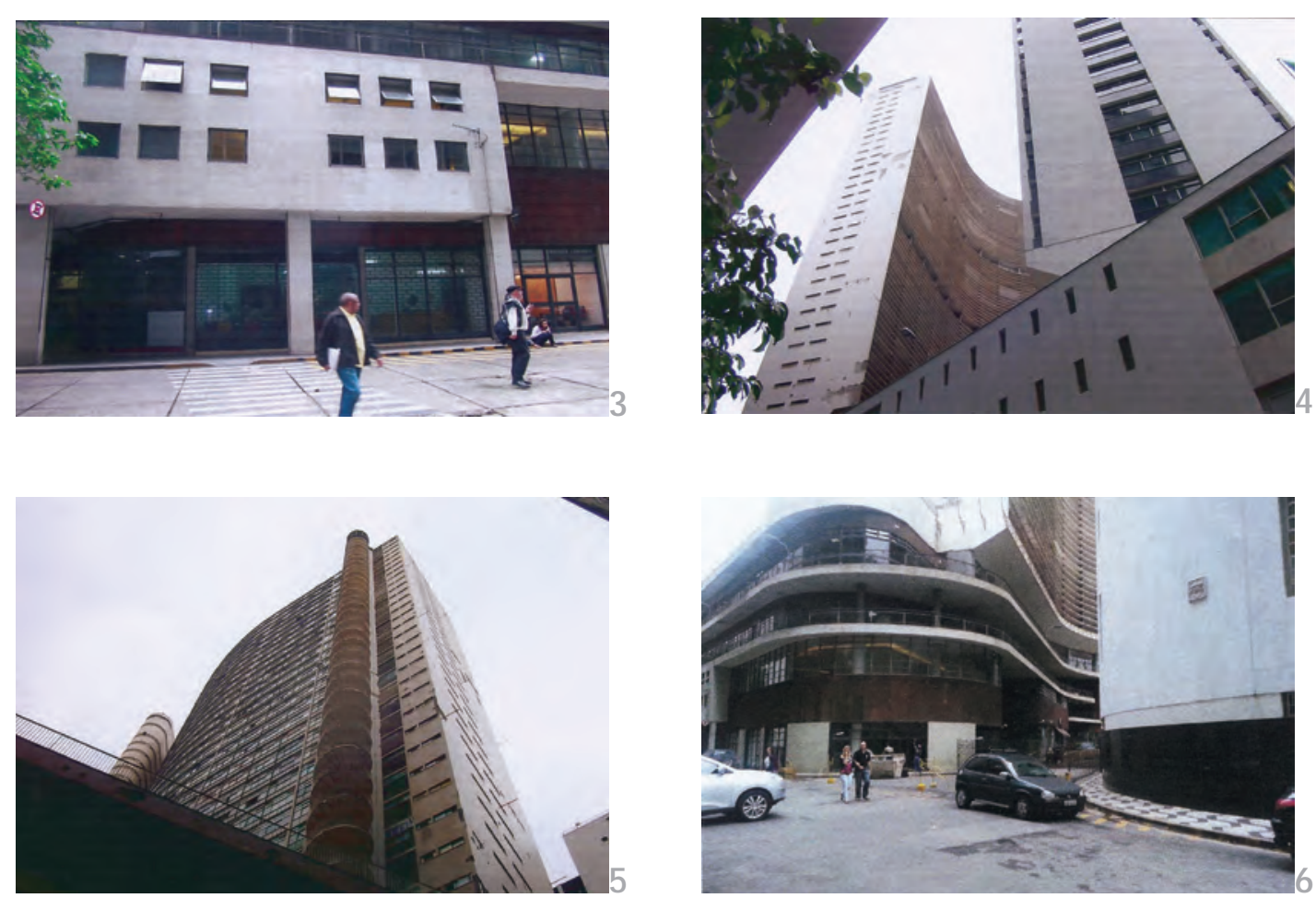

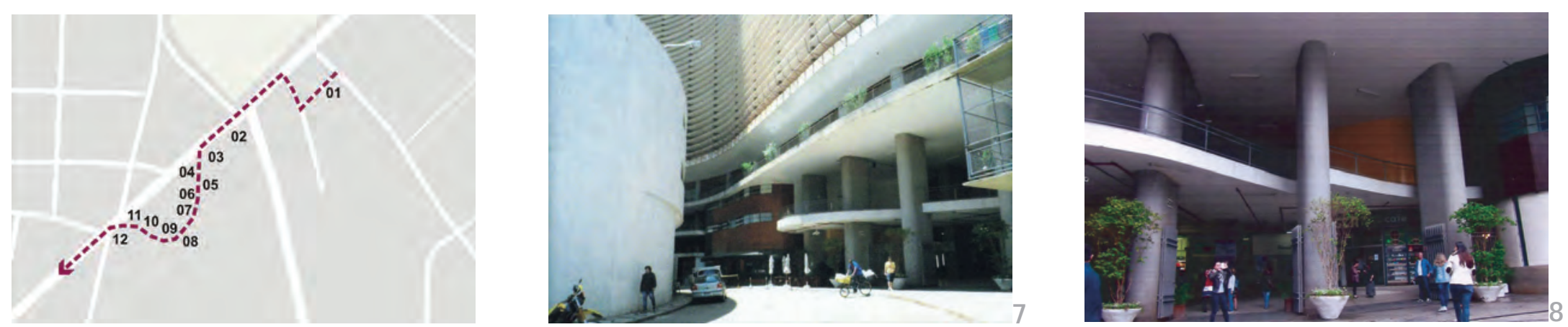

7. Via intema

(vista: entrada da Galeria Copan)

8. Via intema

(vista: saguão da Galeria Copan)

9. Via intema $x$

Avenida Ipiranga

(vista do antigo Hilton Hotel)

10. Via intema $x$
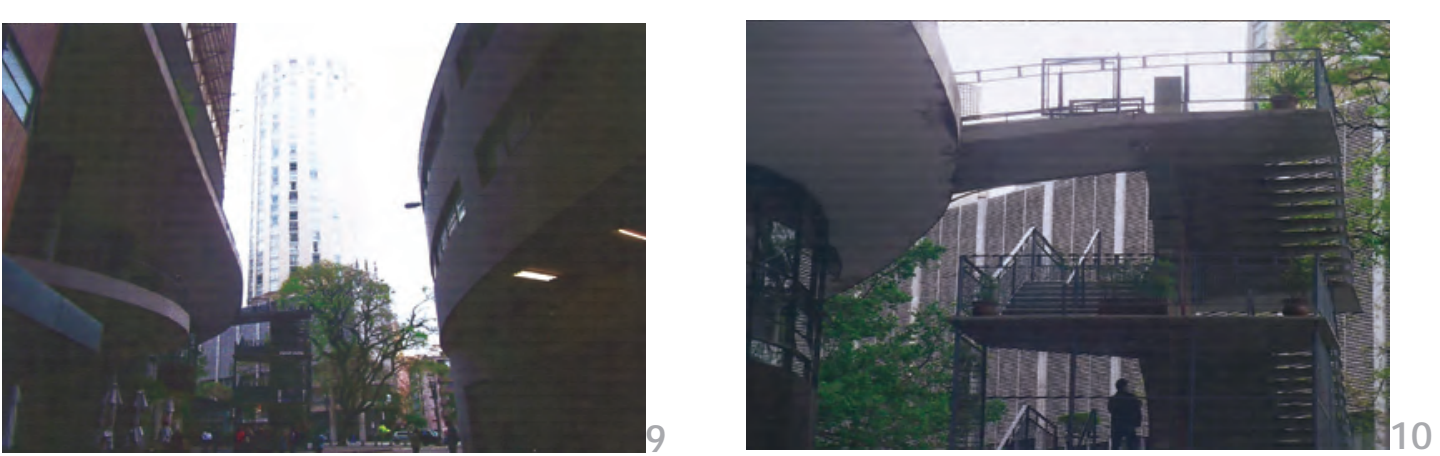

Avenida Ipiranga

(vista de esca daria de

emergência em ferro)

11. Avenida Ipiranga

(detalhe - banca de jomaise Café)

12. Avenida Ipiranga

(vista para Igreja Nossa Senhora da Consolação)
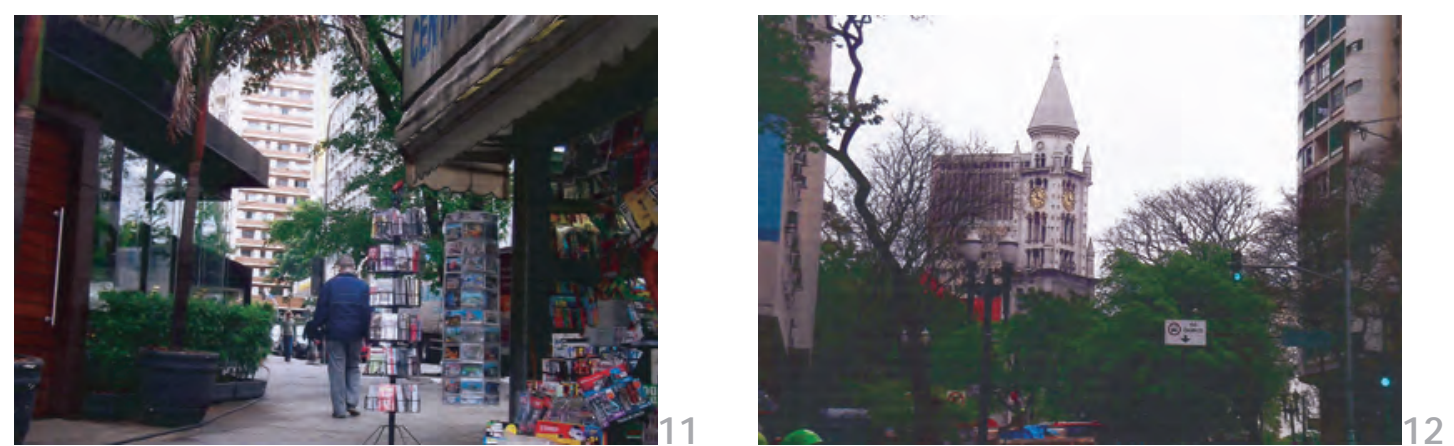


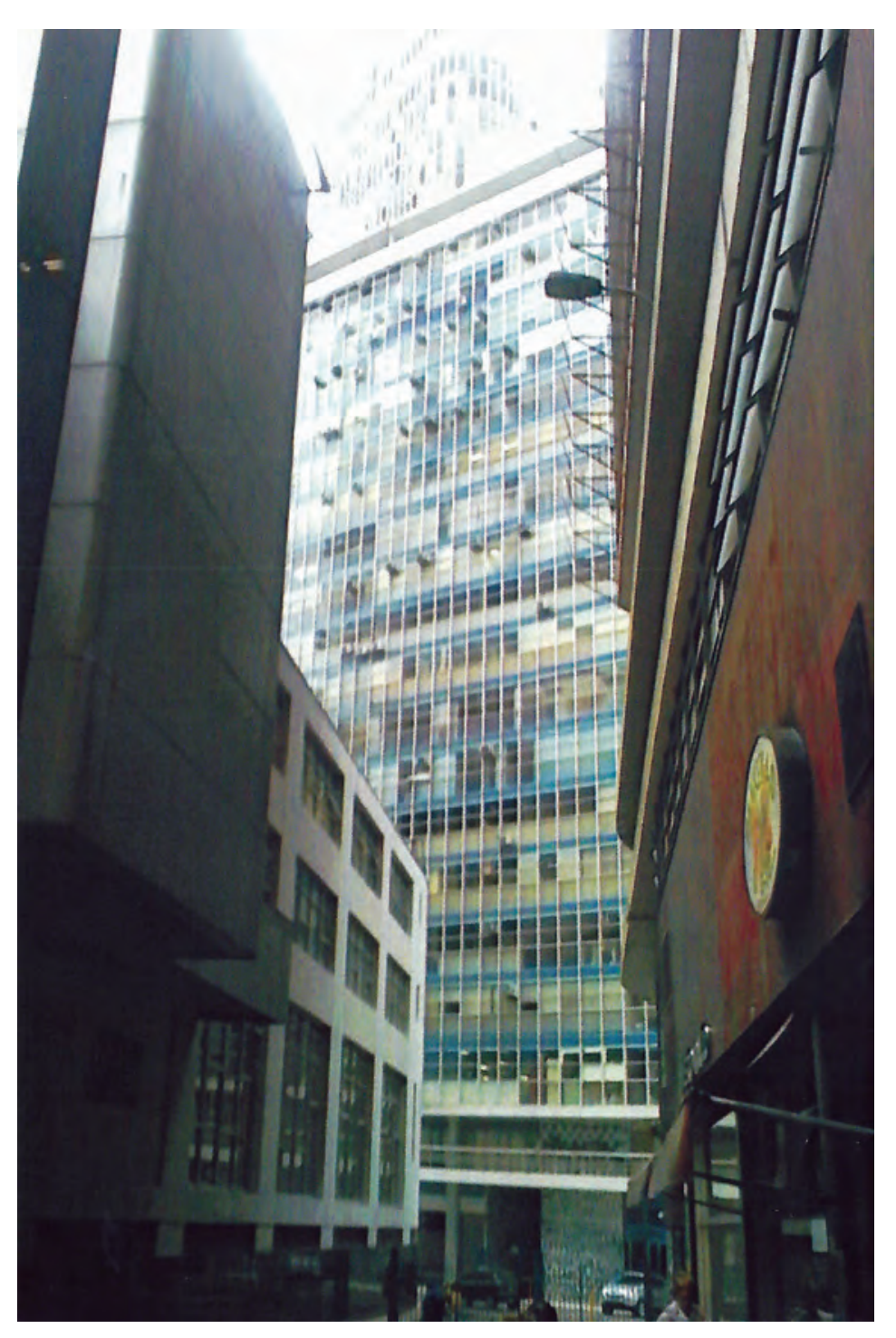




\section{IMPRESSÕES}

Vejo a cidade como uma caixa de fotos - destas que toda família tem. Fica guardada num fundo de armário por anos e vez por outra alguém abre a tampa, para mostrar algo a alguém. As fotos, como cenários, sempre estiveram ali - mas há um momento especial, fora da corrida do cotidiano, que nos detemos a observar - com saudosismo, com espanto frente às mudanças, com distanciamento a aquilo que já não nos faz parte do afeto ou da memória. A cidade é múltipla, mas também individual — onde só reconhecemos o nosso igual! 
Se tivermos que fazer uma arrumação — olhamos por vários momentos, buscando anotações no seu verso - de quem, de quando, de onde. Classificamos pelo interesse - pessoas, tempo, lugares, afinidades que as lembranças despertam ou não. As primeiras exclusões nesta arrumação são sempre por aquilo que não identificamos, que não reconhecemos - um tio malquisto, a amiga desconhecida de uma afilhada que ninguém conhece ou lembra, uma imagem tola de si mesmo ou um lugar de uma viagem desastrosa.

E no monte das imagens queridas - todos remetem a empatia - dos entes mais queridos vivos ou falecidos - em que nos embarca na nostalgia ou na estranheza. As fotos comprovam que alguém ou algo existiu - e há uma linha que acontece entre dois tempos, entre dois mundos: Nunca vi pessoalmente minha avó-mocinha... Mas lá está ela na imagem. Interessa-me seu olhar e seu penteado de época - onde ela estaria naquele momento, o que pensava enquanto registravam sua imagem?

A cidade é fragmento. Fragmento de ações, de tempos, de lembranças — onde só se guarda aquilo que faz sentido. Não é a toda que é tão mal preservada, se boa parte das pessoas que a usam não se identificam com ela, não há lembranças da passagem delas antes ou de seus pais, ou de seus avós. Se olharmos com muita atenção, os fragmentos se sobrepõem — assim como se sobrepõem os períodos, os gostos, os usos.

A pluralidade fica ainda mais latente numa cidade mestiça - de muitos imigrantes e suas heranças, de muitos estrangeiros da própria terra que trazem consigo parte do que deixaram para trás, para justamente se sentirem em casa. Olhar atentamente é perceber os cantinhos preservados, os guetos de uma identidade - que estão sujeitos também a intervenções de quem por eles passam. 
No centro, onde a vida é mais latente, o conflito maior e as diferenças mais expressivas - é onde tudo acontece, se sobrepõe e coexiste. Por isto vejo que ao contrário do pensamento europeu, não temos condições de estabelec er matizes cromátic os que as pessoas possa m de fato se identificar - mas talvez combinações harmônicas que nos fazem aproximar. 
NARRATIVAS VISUAIS

RAGMENIOS 


\section{MEMÓRIA}

O registro a tra vés da pintura de uma imagem observada, que é marcado pela subjetividade, pois trata em algum nível de expressão do relato da experiência vivida do seu autor, demonstra peculiaridades e escolhas pessoais. Apesar de Michael Pollak (Memória e identidade social, in: Estud os Históric os, vol 5 n. 10. Rio de Janeiro, 1992) enfatiza que a história pessoal é perpassada e nuançada pela história sociocultural em que estamos todos inseridos. As memórias individuais são constituídas da vivencia social compartilhada, porém serão sempre únicas e singulares. 
A individualidade da memória e do olhar explica boa parte dos diferentes resultados da representação do mesmo lugar. Toda representação é carregada de fatores emotivos, quer seja intuitivos e vivenciais, quer seja de saberes inconscientes, incorporados da nossa cultura. A representação é interpretação, não única possível, que se distancia da descoberta e se aproxima do reencontro de pensamentos achados, retirados de um baú de pertences queridos, onde talvez sempre estivessem à nossa espera.

Diferente do que acontece num trajeto, a imagem selecionada é estudada e absorvida antes mesmo de sua representação. A opção pela técnica de aguadas da aquarela, permite que a expressão da cor seja absorvida rapidamente, atentando-se pela sua proporção, e posição no campo visual.

A seleção da técnica corresponde a uma seletividade da pessoa; assim, a real opção talvez nem se dê em termos tão conscientes, obedecendo antes, uma predeterminação interiorizada que encontra no momento oportuno uma espécie de pretexto para se manifestar e buscar uma linguagem visual adequada.

O pensamento imaginativo começa a especular, orientando-se em viabilidades da matéria para configurar formas expressivas, sondando quanto a aspectos específicos que pudessem caracterizar essa matéria num sentido essencial e talvez novo. Sondar as possibilidades da linguagem é estar vulnerável ao impacto de realidades que se revelam diferentes das que se imaginava ou se previa. O foco neste olhar é a própria cor, que assume autonomia e não se prende a forma, ora se ilumina, ora se dilui em transparências. 


\section{REGISTROS PICTOGRÁRCOS}

"A cidade é redundante: repete-se para fixar alguma coisa (...). A memória é redundante: repete os símbolos para que a cidade comece a existir"

(CALVINO, 2001, p. 23) 
A cidade é fragmentada - relata varias época, costumes, valores sociais, que coexistem, nem se fundem, nem se excluem, contudo se submetem aos caprichos de seus habitantes.

A cidade é vista sob todas as luzes possíveis — reais e imagináveis.

O desenho de uma cidade pode ser percebido como uma arte temporal, mas diferente de outras artes temporais, não se pode repetir sequências controladas na sua construção; tais sequências, observáveis no espaço, são percebidas de forma muito particular para quem as observam - parecem interrompidas, continuas, invertidas, abandonadas.

O que distingue seus lugares aprazíveis, seus conjuntos harmônicos e estéticos, seus contrastes, são os olhos de quem as vê - e mesmo assim, são sensações mutantes e repletas de interpretações a serem exploradas.

A cidade é organismo vivo que se adapta as novas funções e se reinventa conforme os desejos e sonhos de quem a constrói e destrói - permanece apenas o que tem sentido, o que não tem é esquecido e logo substituído.

A sequência de aquarelas que se segue representa fragmentos da cidade, escolhidos pelo atrativo da memória que remetem da cidade, em particular o Centro Velho de São Paulo e algumas regiões do seu entorno; e pelo recorte da expressividade da Cor nesses lugares públicos, de grande circulação de transeuntes. É uma leitura poética e particular. 
avenida paulista: $\mathbf{p . 1 1 8}$

biblioteca mário de andrade: $\mathbf{p . 1 1 9}$

casarão n 1919, avenida paulista: $\mathbf{p . 1 2 0}$

casarão da rua 13 de maio: $\mathbf{p . 1 2 1}$

casarão da rua 13 de maio - praça dom orione: $\mathbf{p . 1 2 2}$

catedral da sé: $\mathbf{p . 1 2 3}$

edifício central banco do brasil: $\mathbf{p . 1 2 4}$

edifício copan: $\mathbf{p . 1 2 5}$

edifício fiesp: $\mathbf{p . 1 2 6}$

edifício hotel, rua martins fontes: $\mathbf{p . 1 2 7}$

edifício martinelli: $\mathbf{p . 1 2 8}$

edifícios da rua florêncio de abreu: $\mathbf{p . 1 2 9}$

galeria 24 de maio: $\mathbf{p . 1 3 0}$

MASP: p.131

pateo do collegio: $\mathbf{p . 1 3 2}$

praça monumento, pateo do collegio: $\mathbf{p . 1 3 3}$

rua líbero badaró: $\mathbf{p . 1 3 4}$

sesc pompeia: p.135

solarda marquesa: $\mathbf{p . 1 3 6}$

viaduto santa ifigênia: $\mathbf{p . 1 3 7}$ 


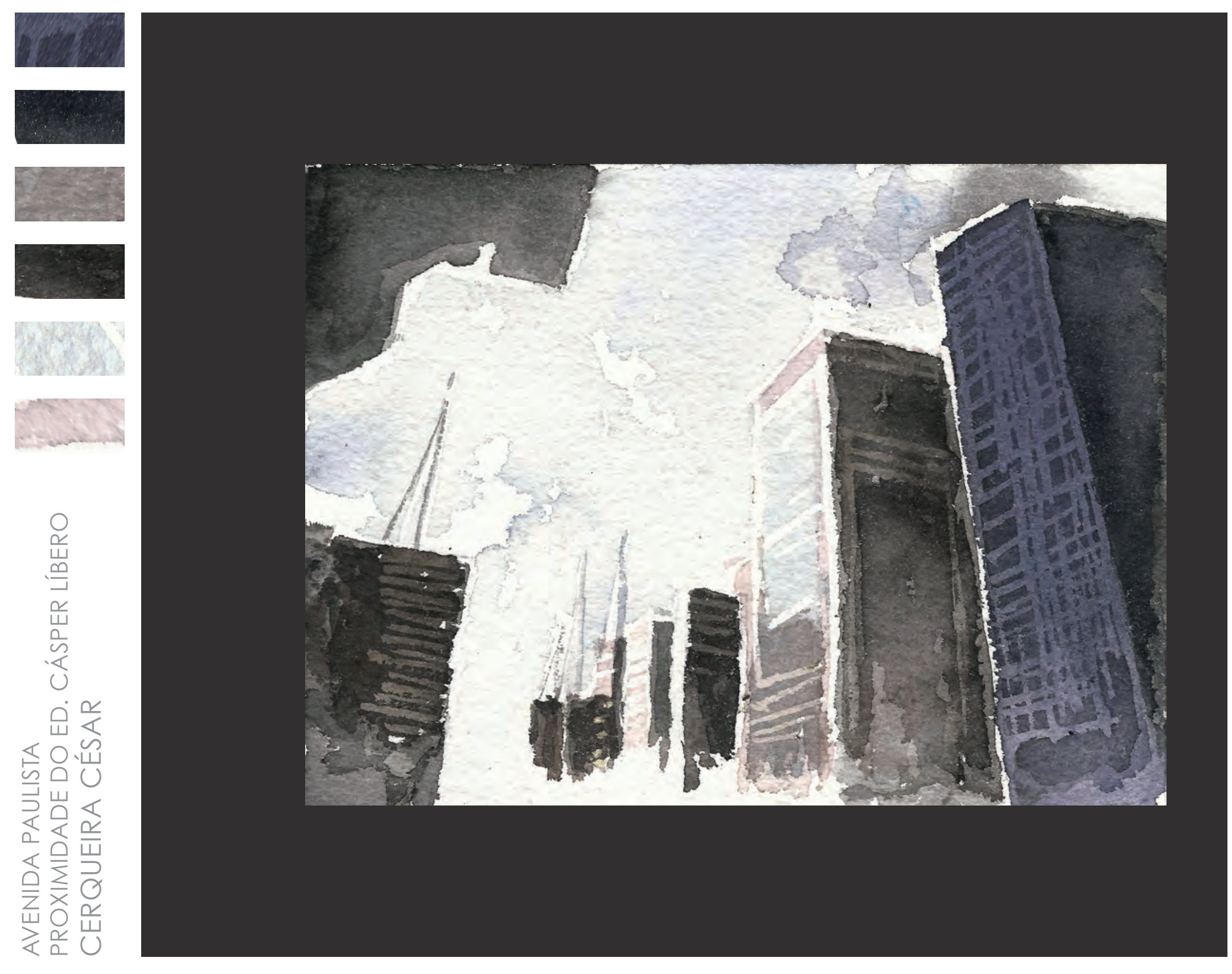




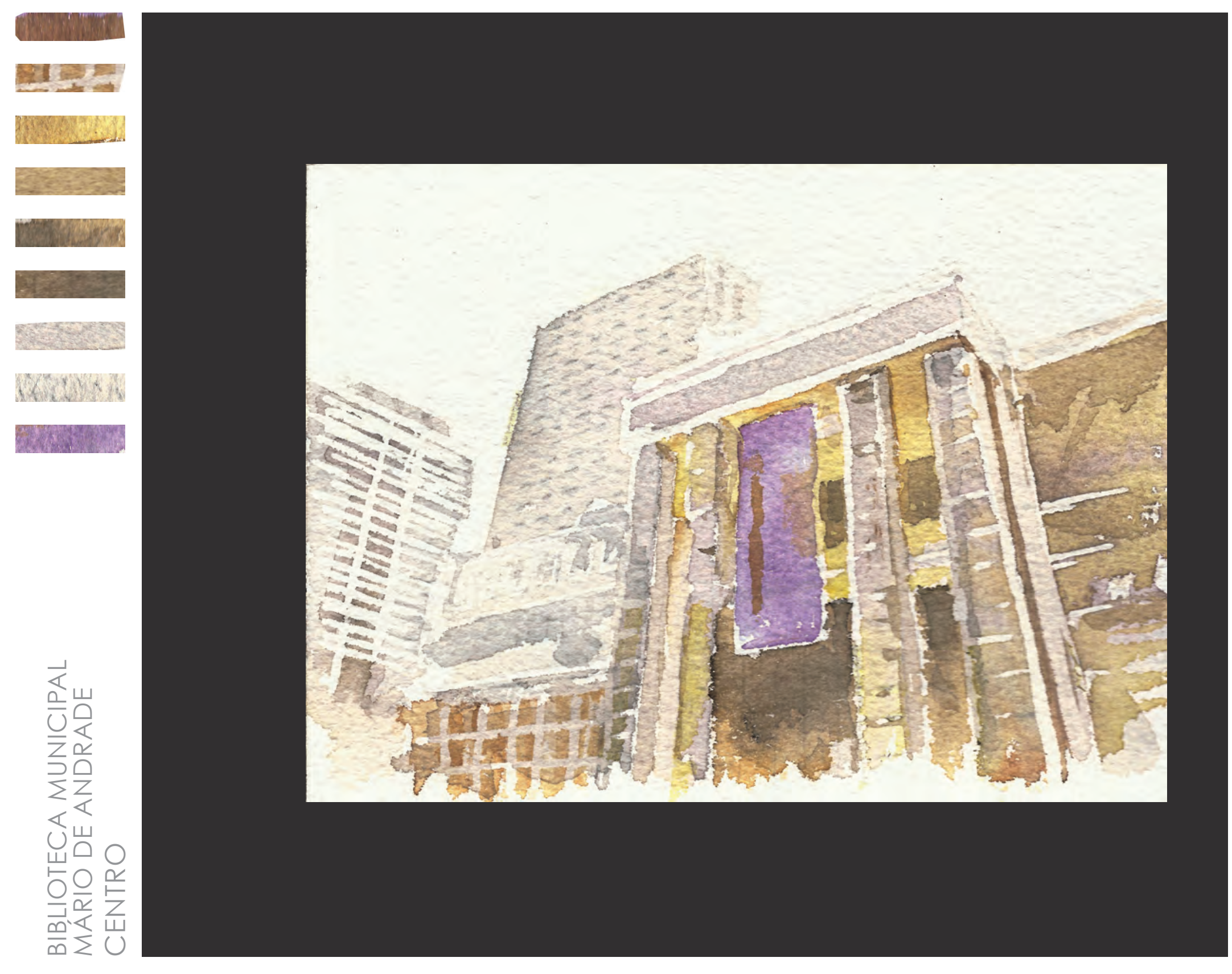




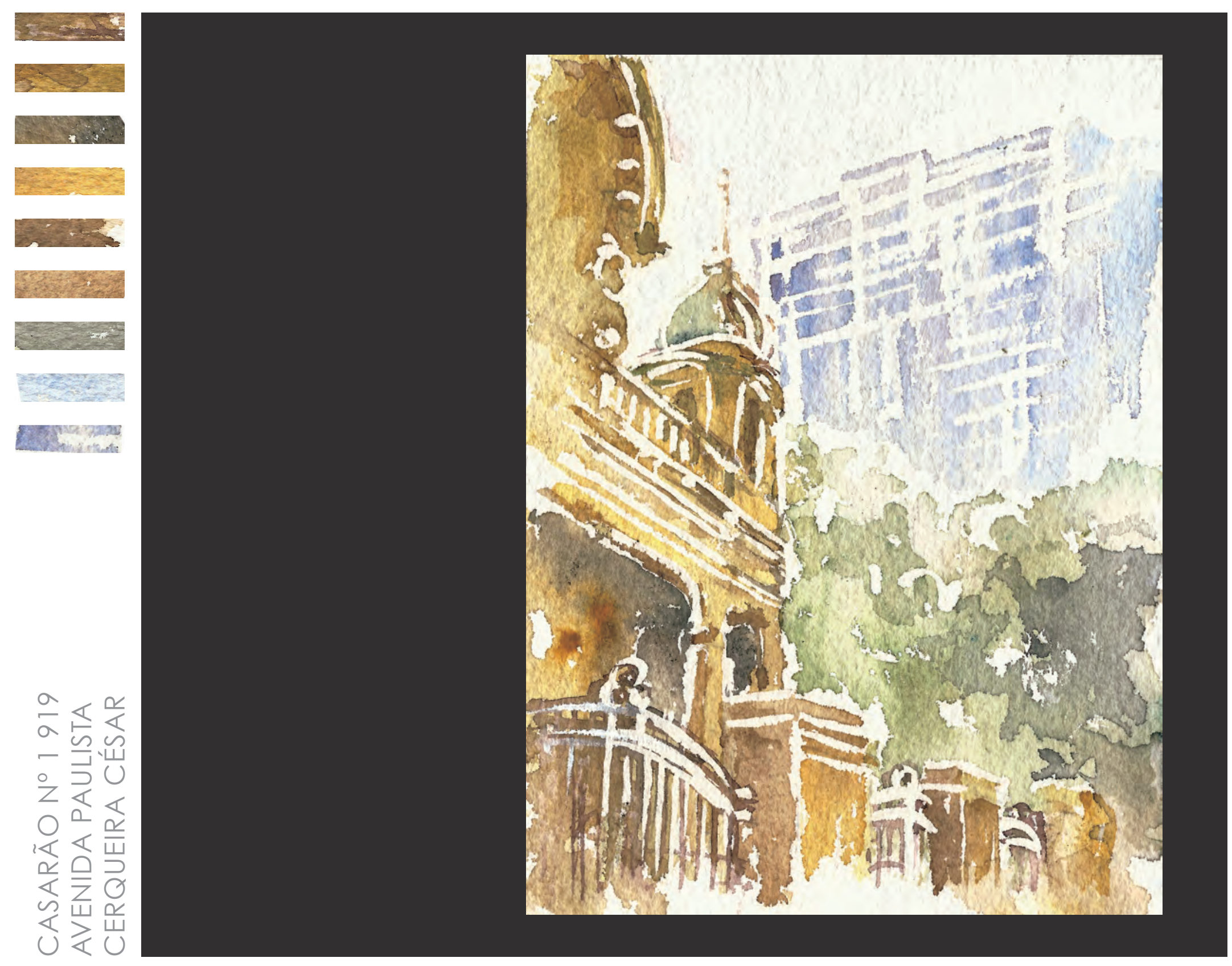




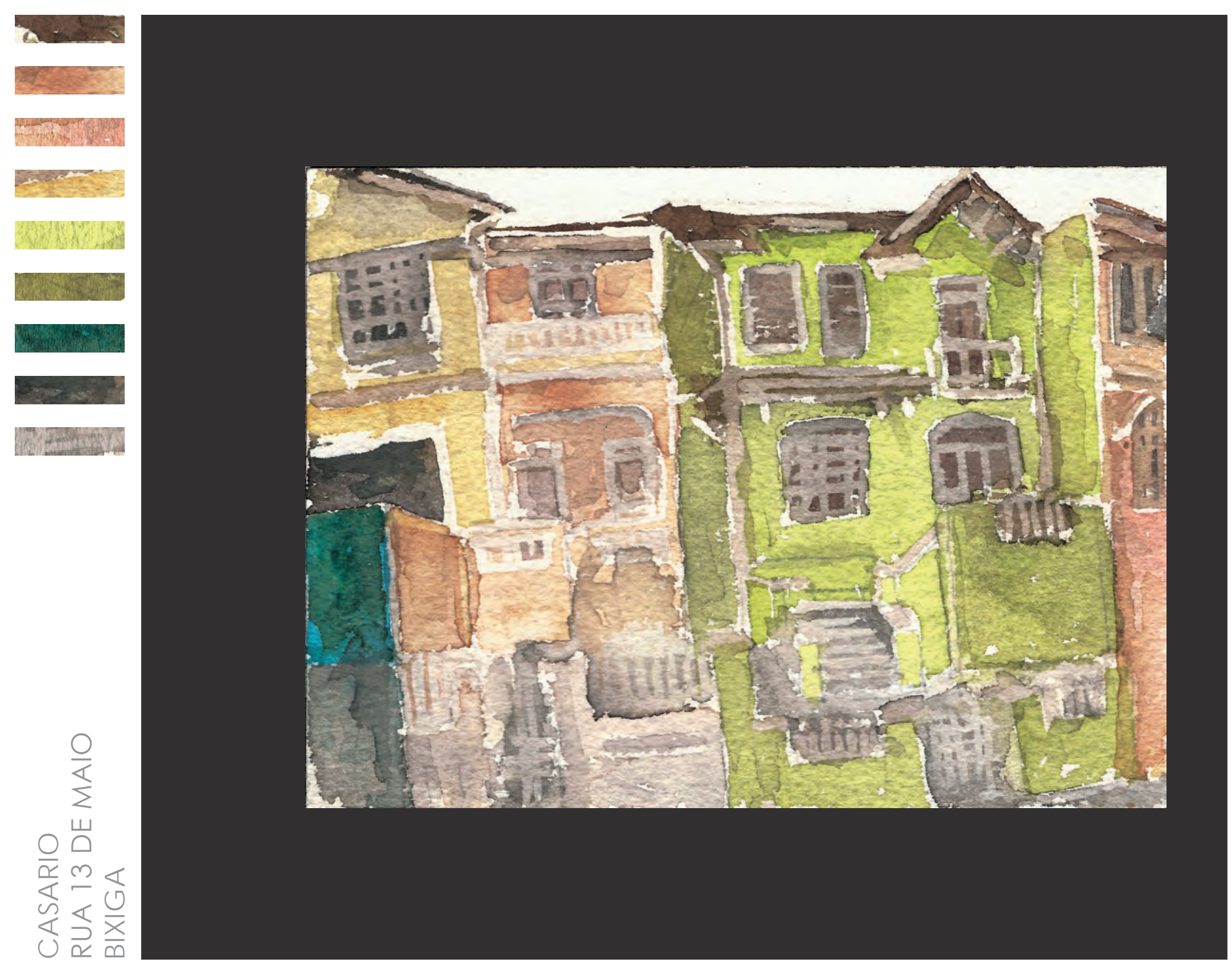




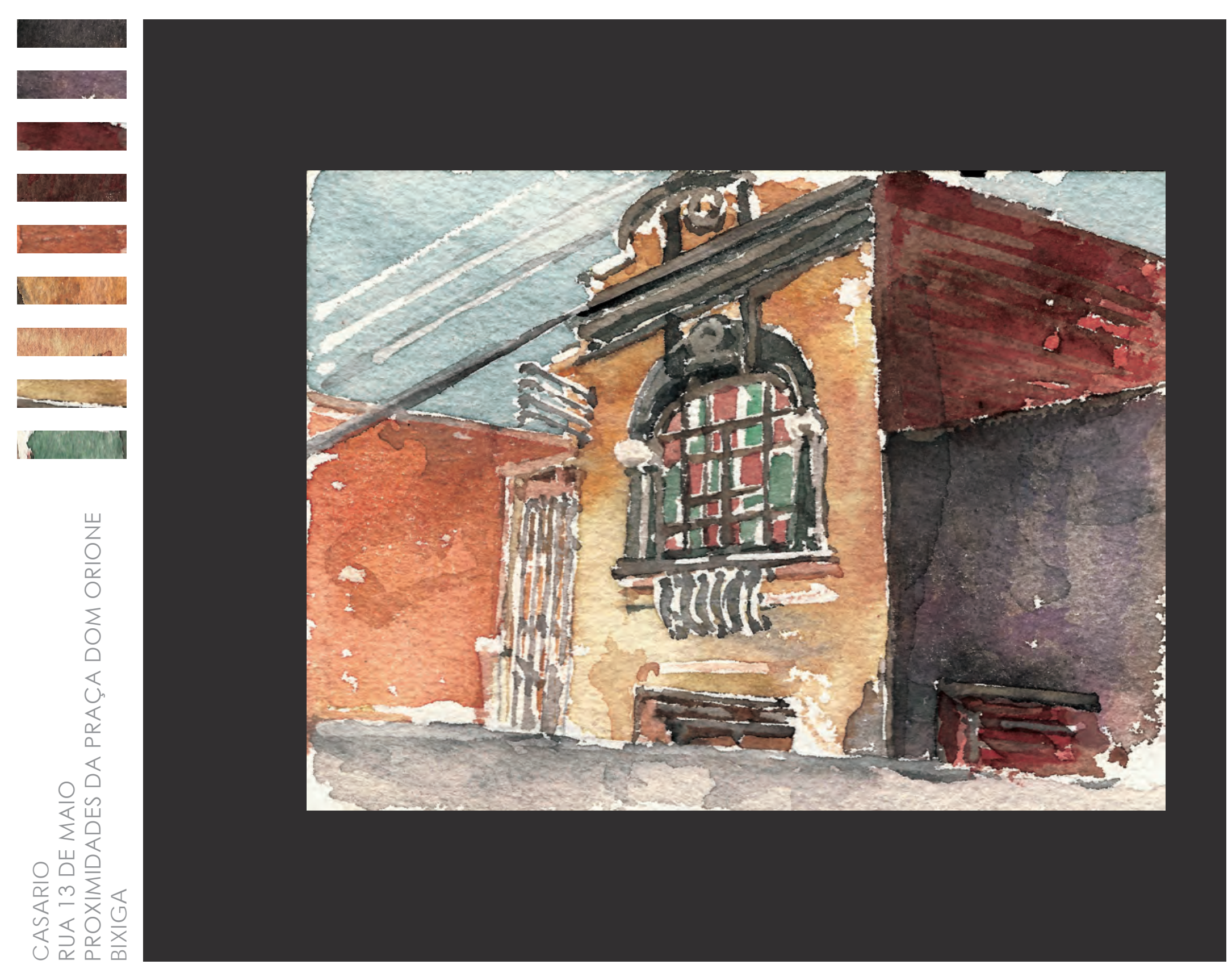




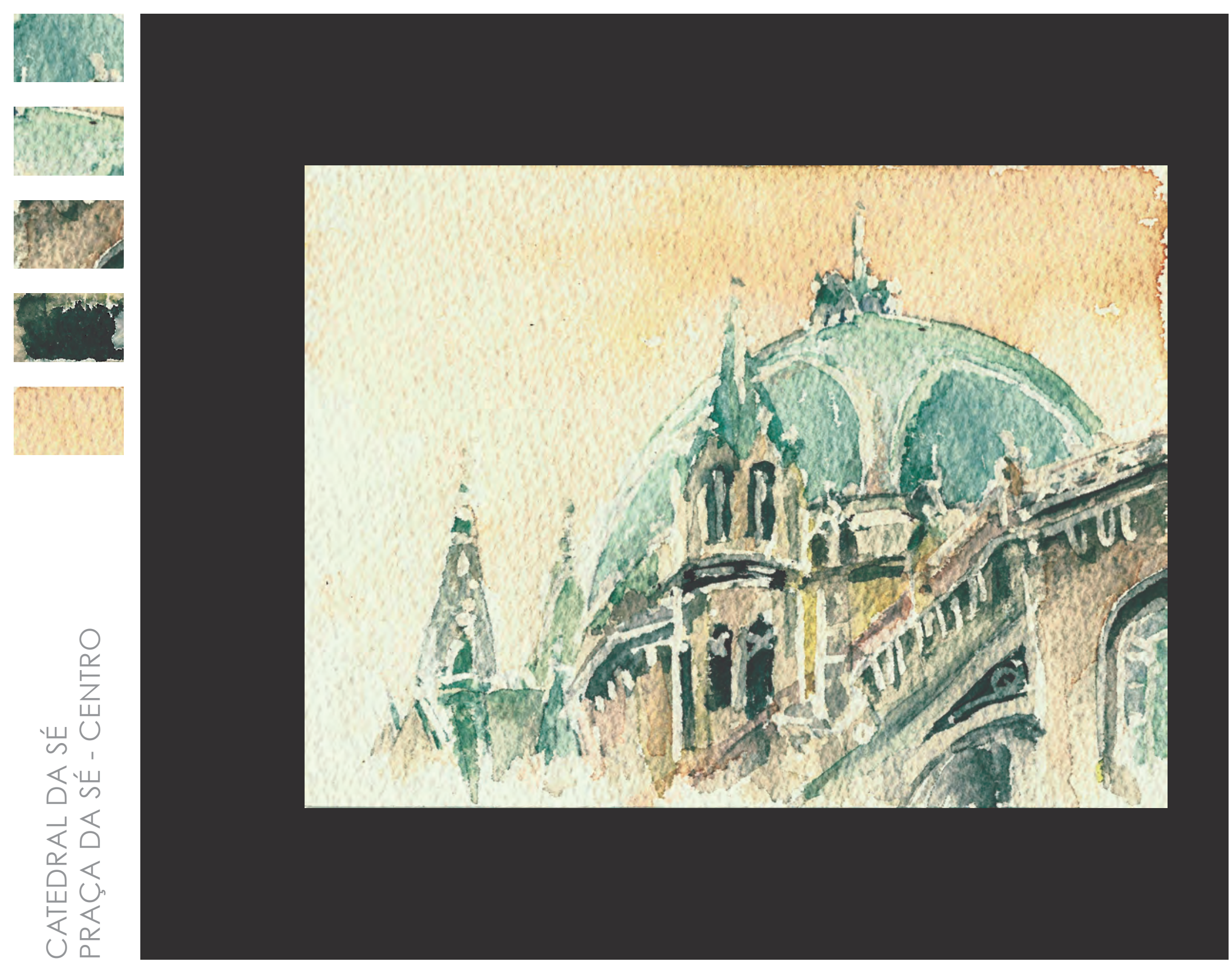




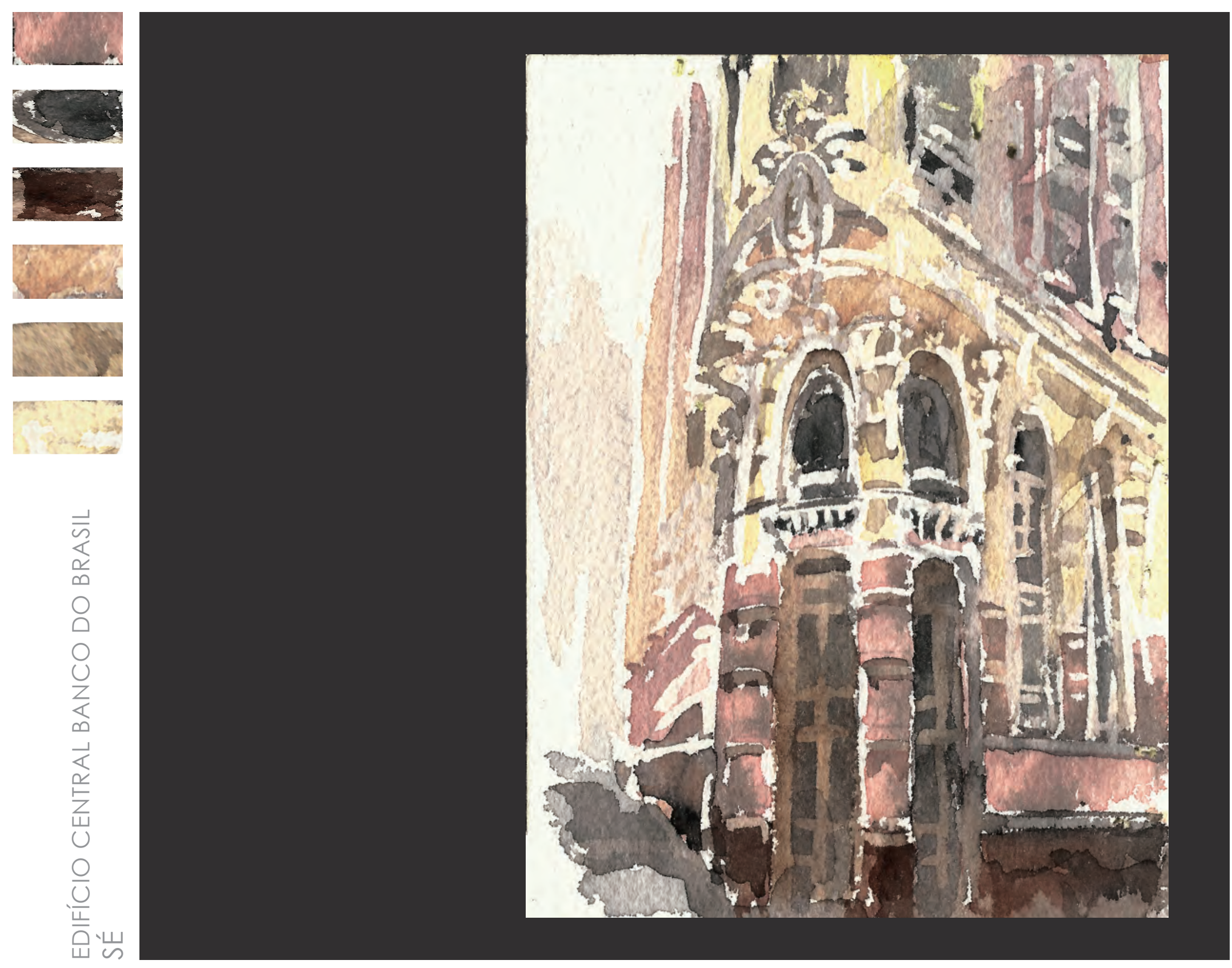




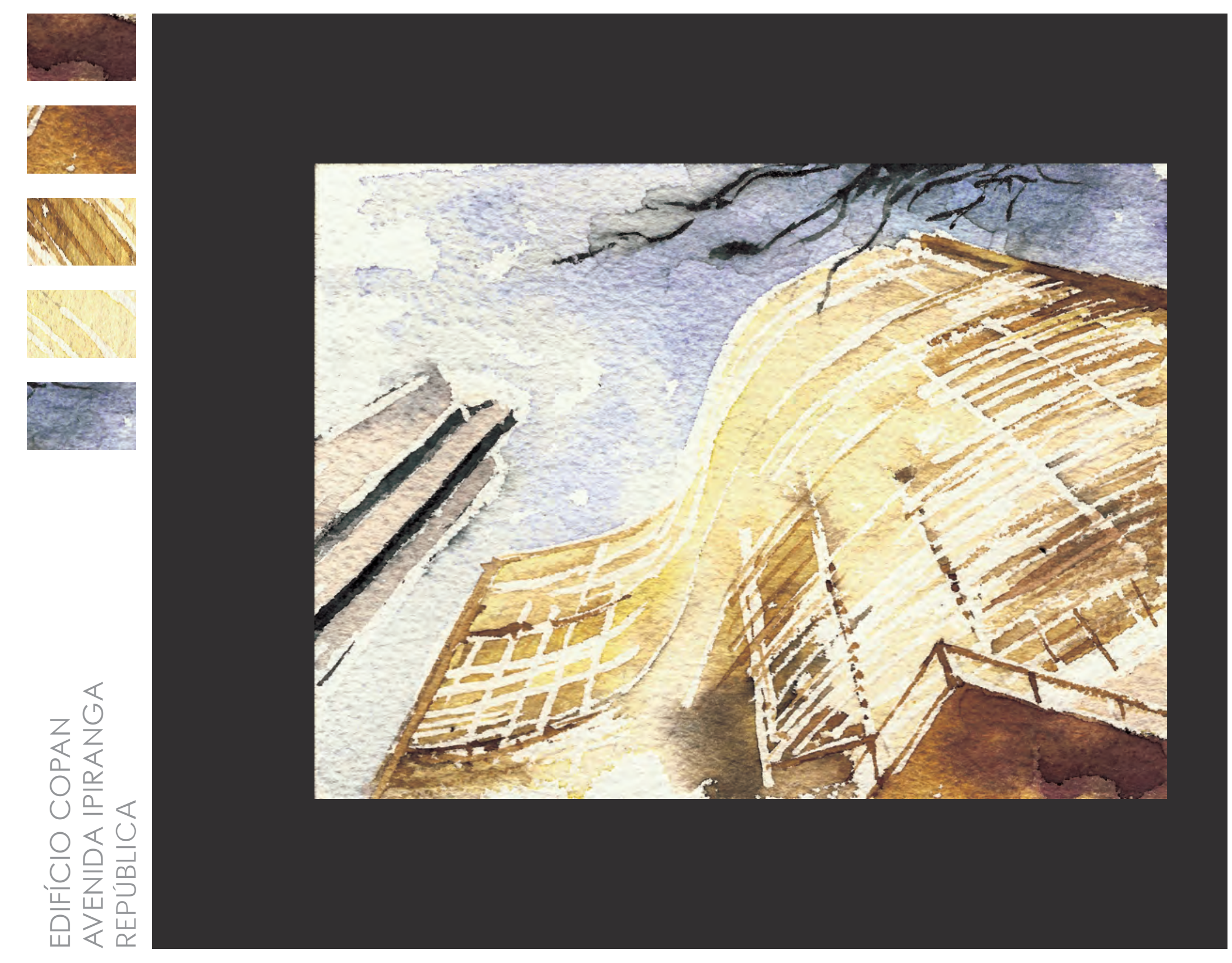




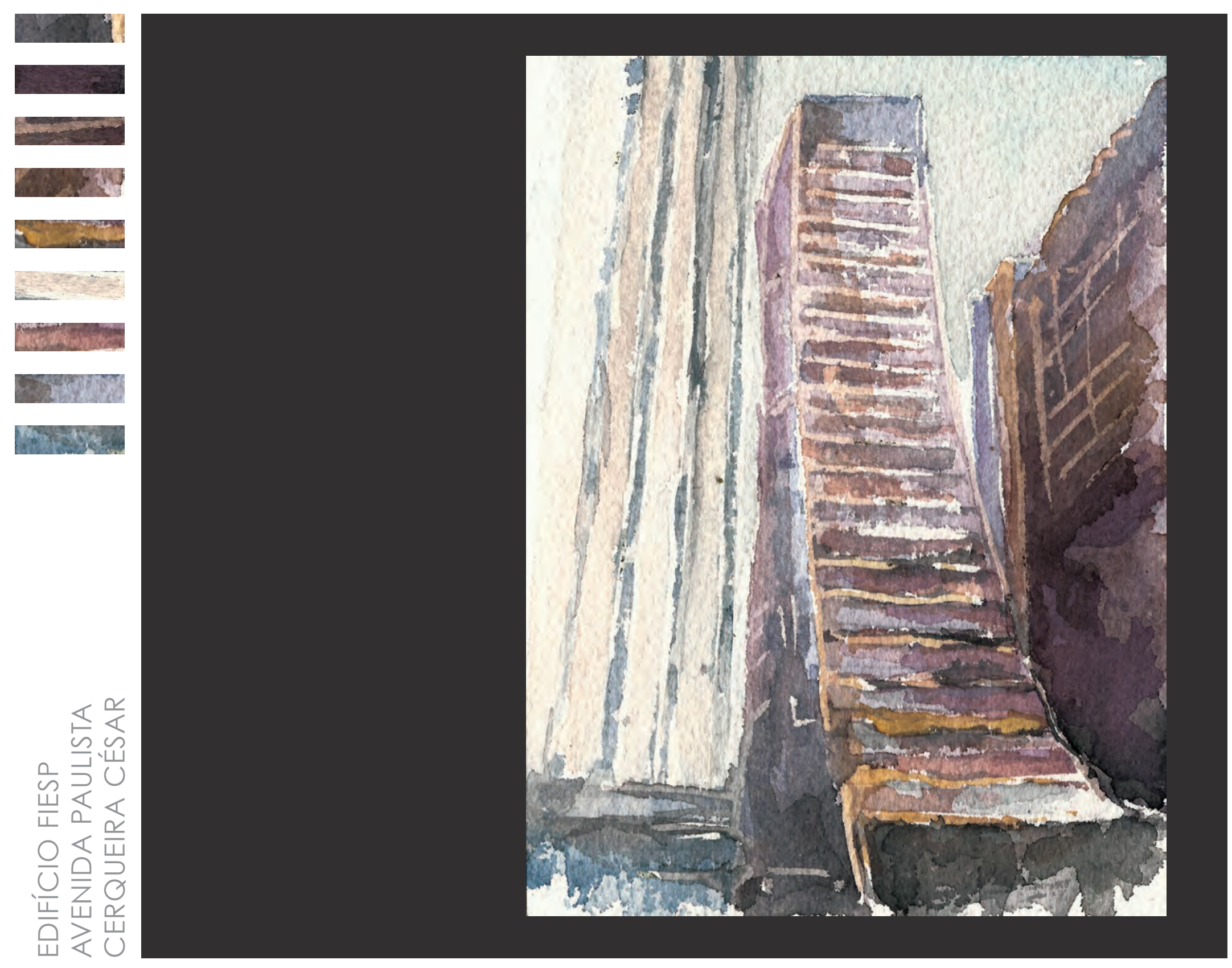




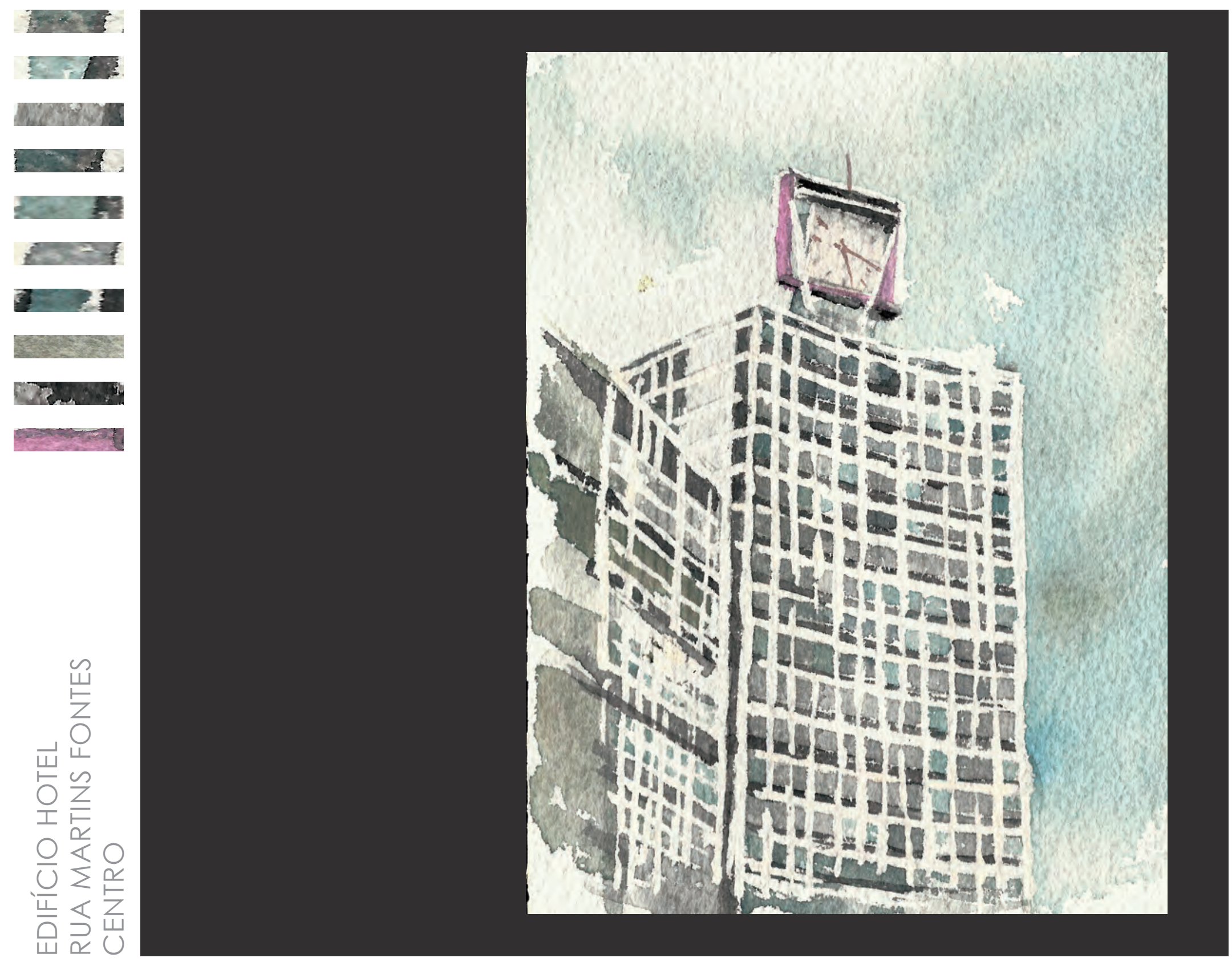




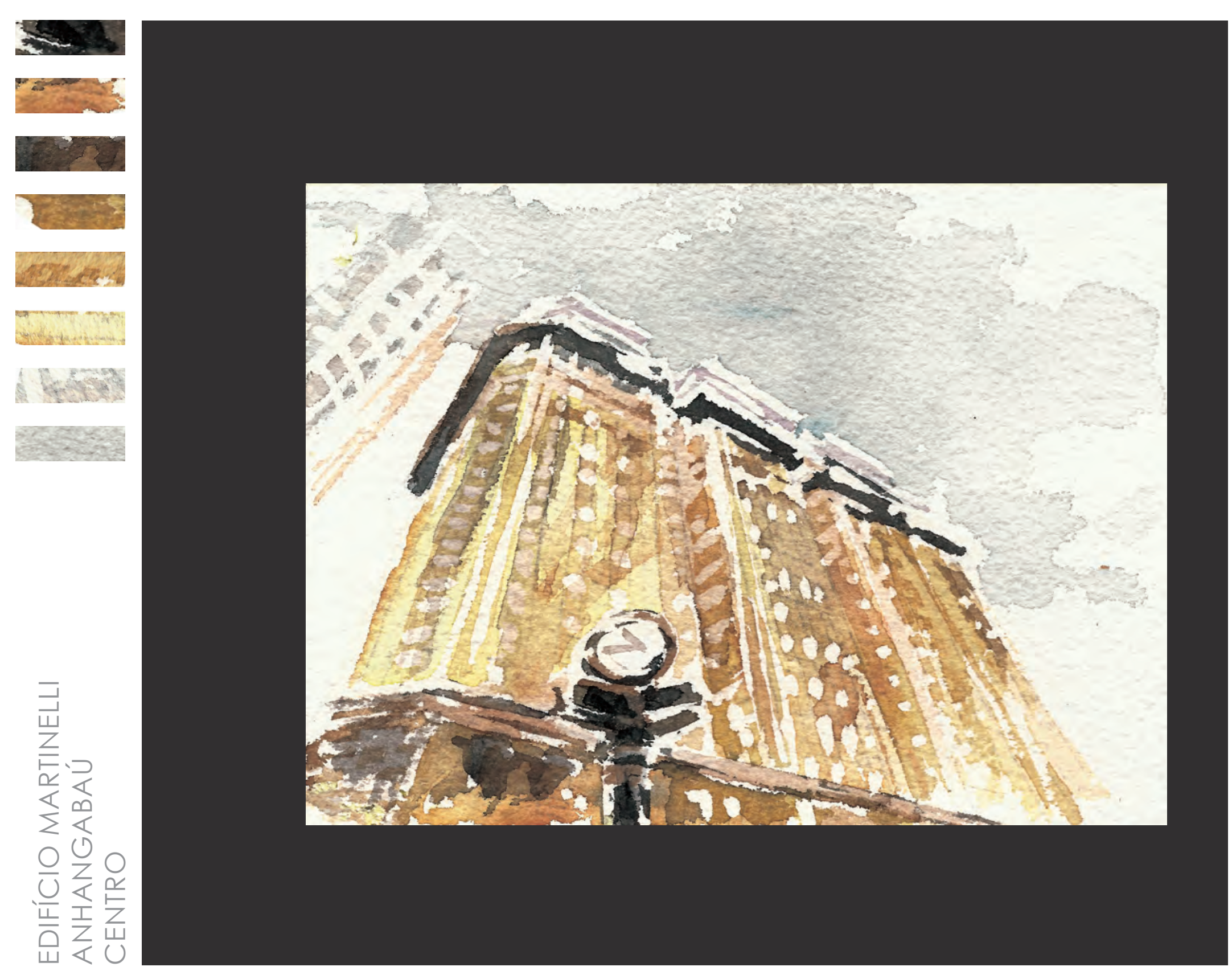




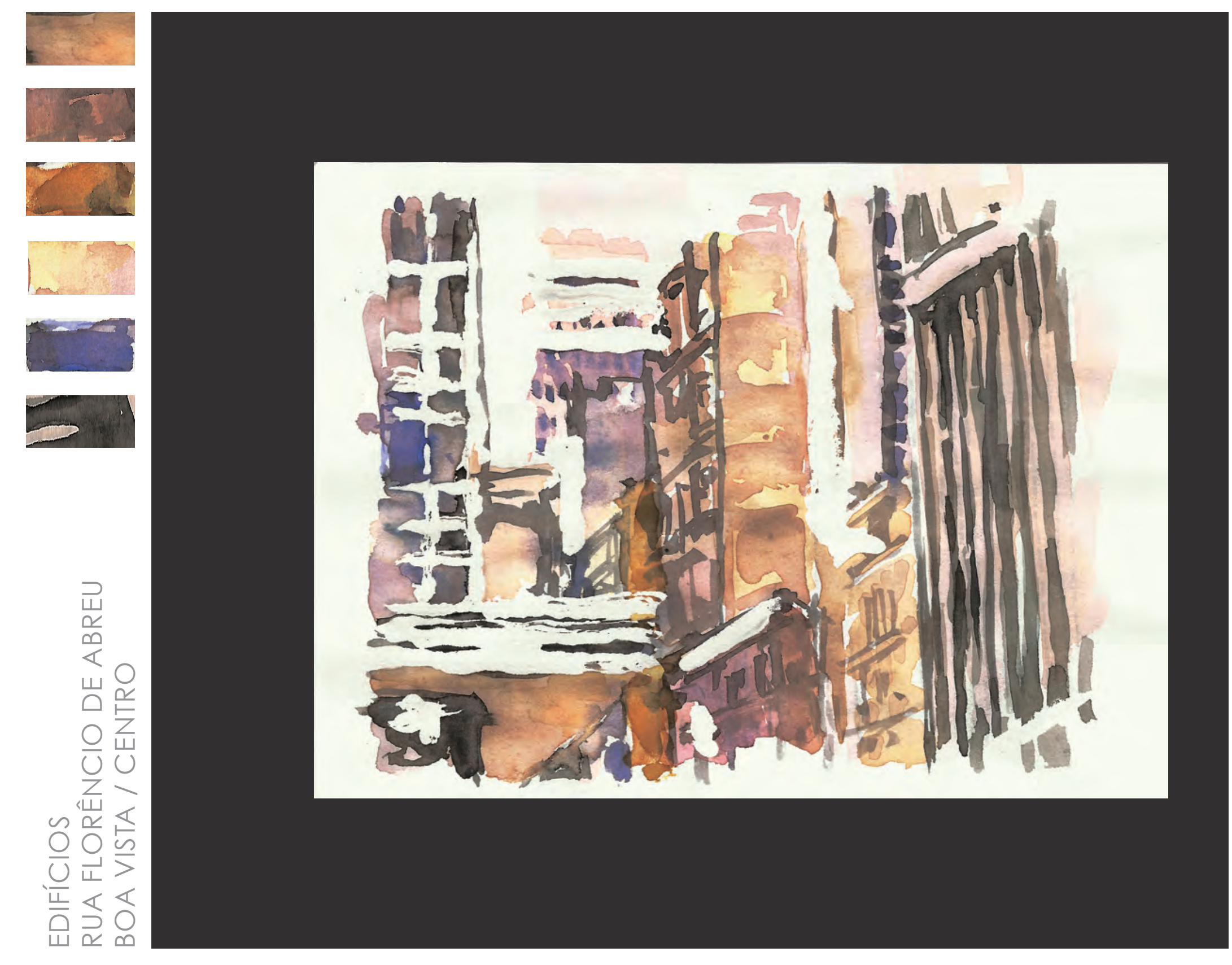




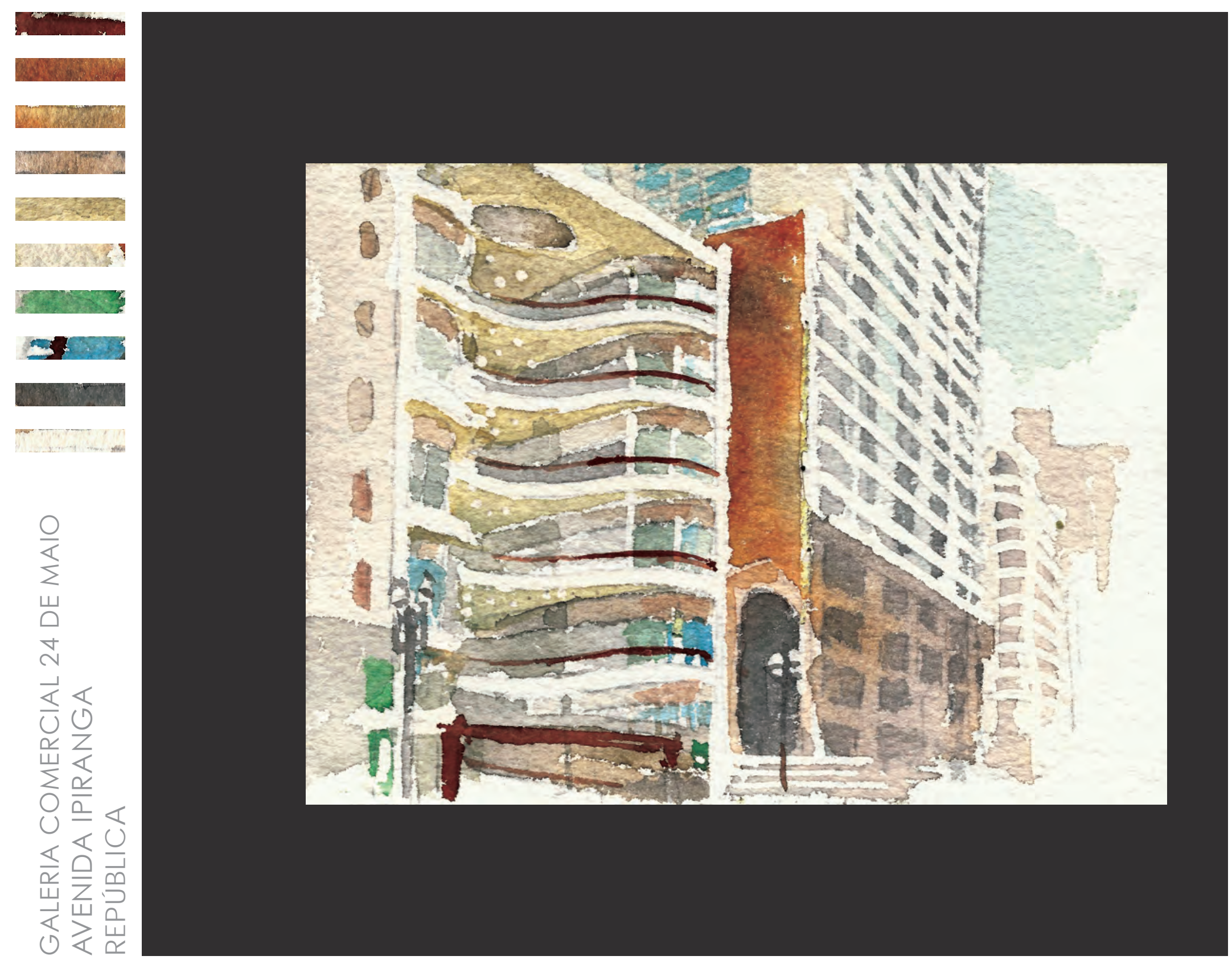




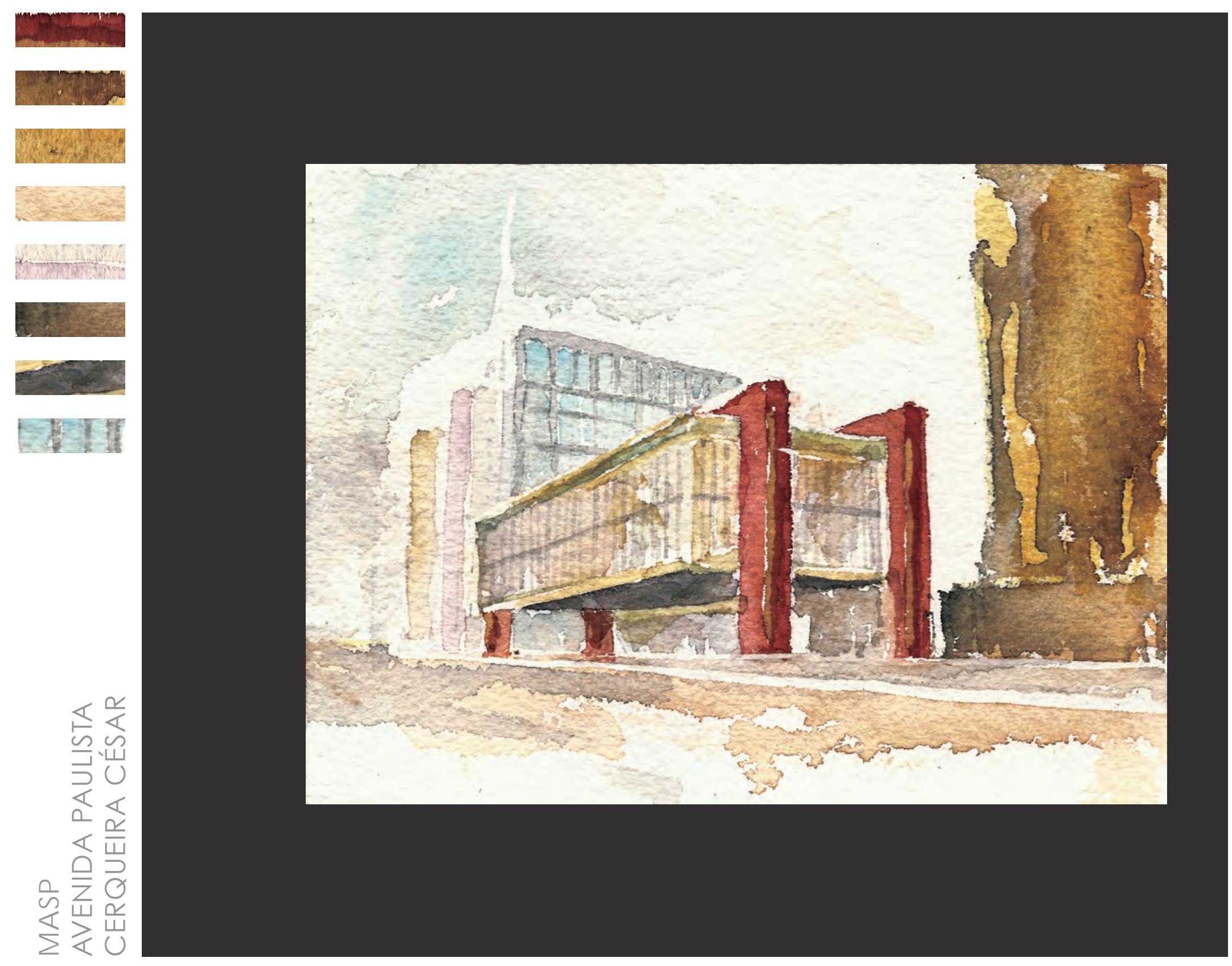




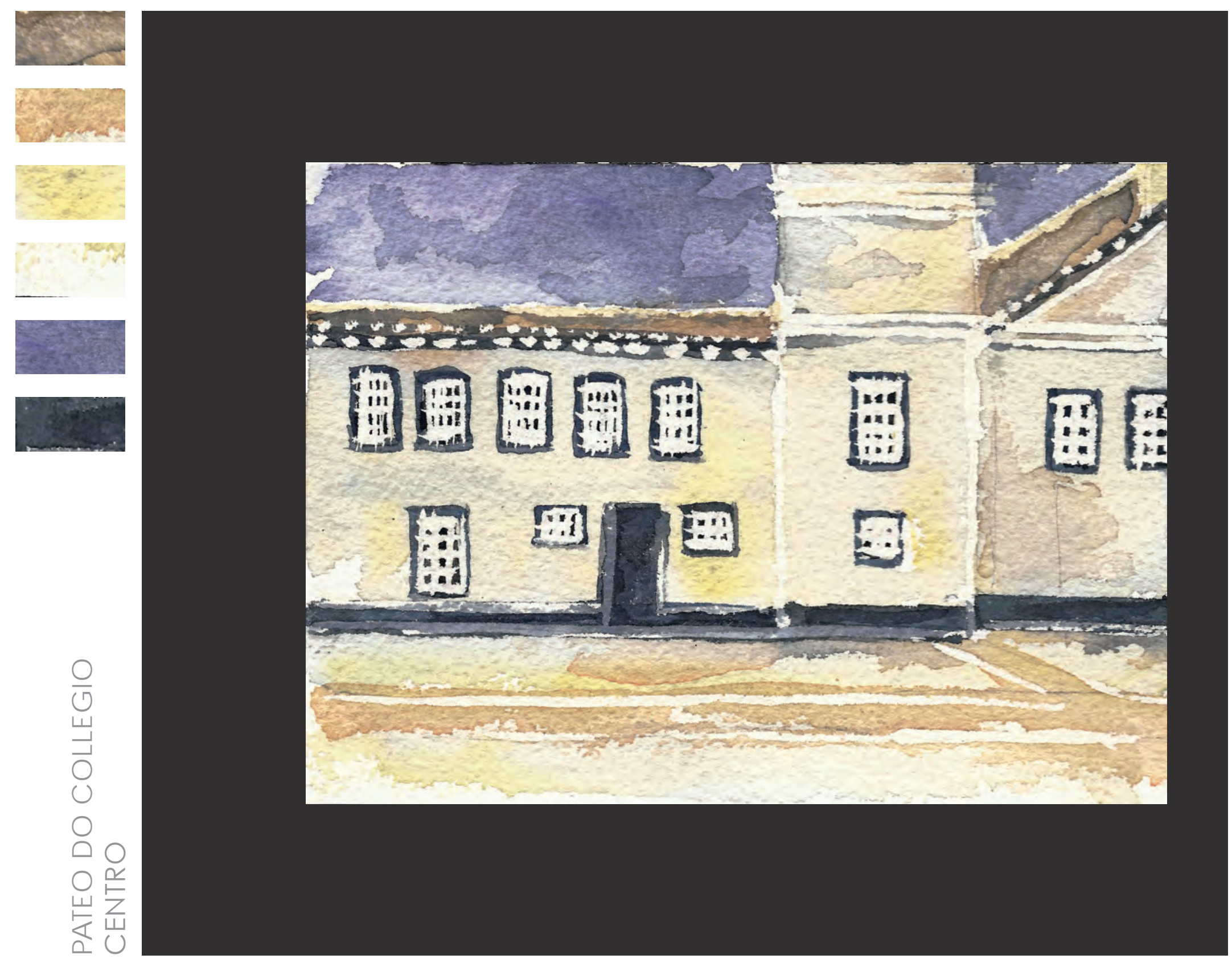




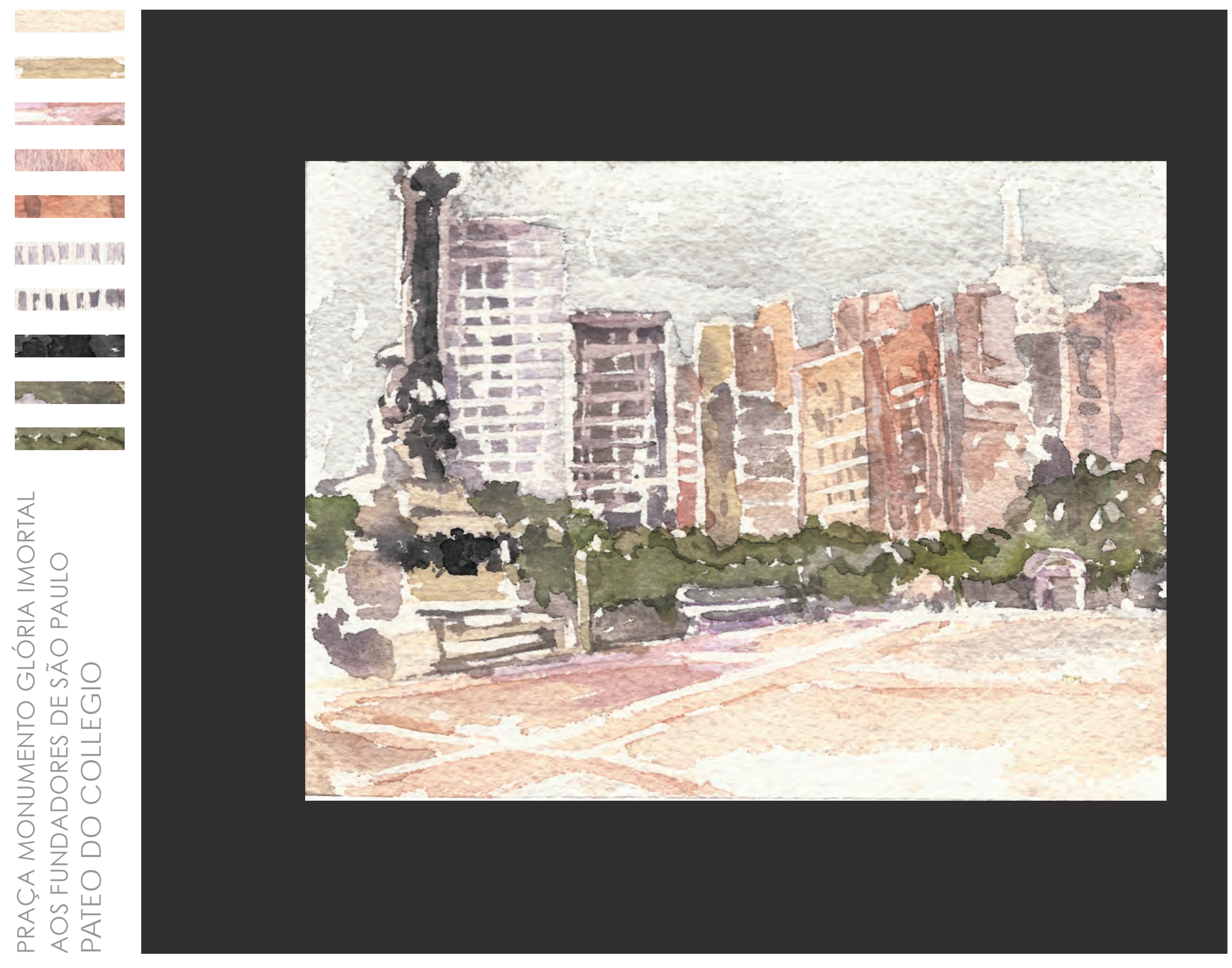




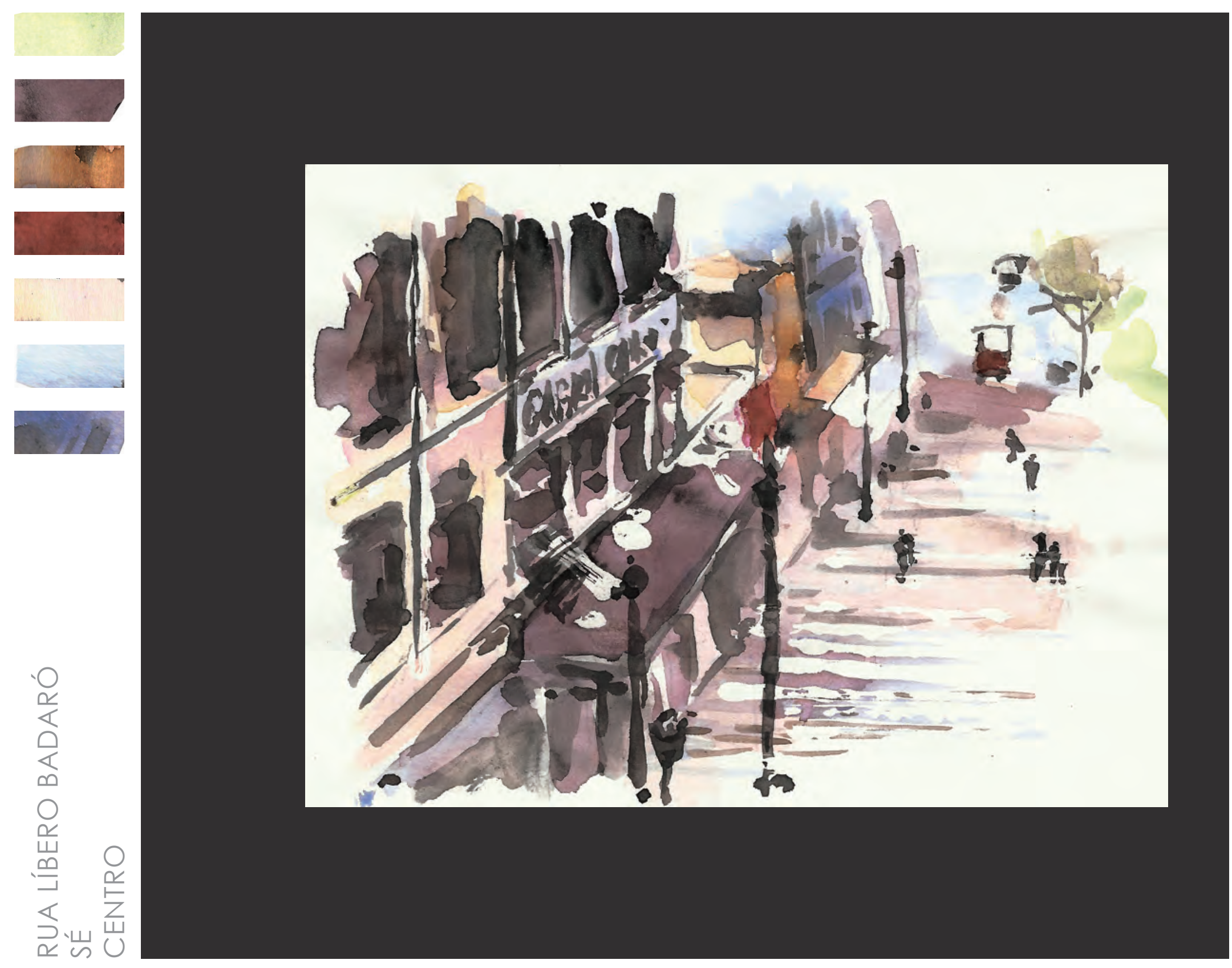




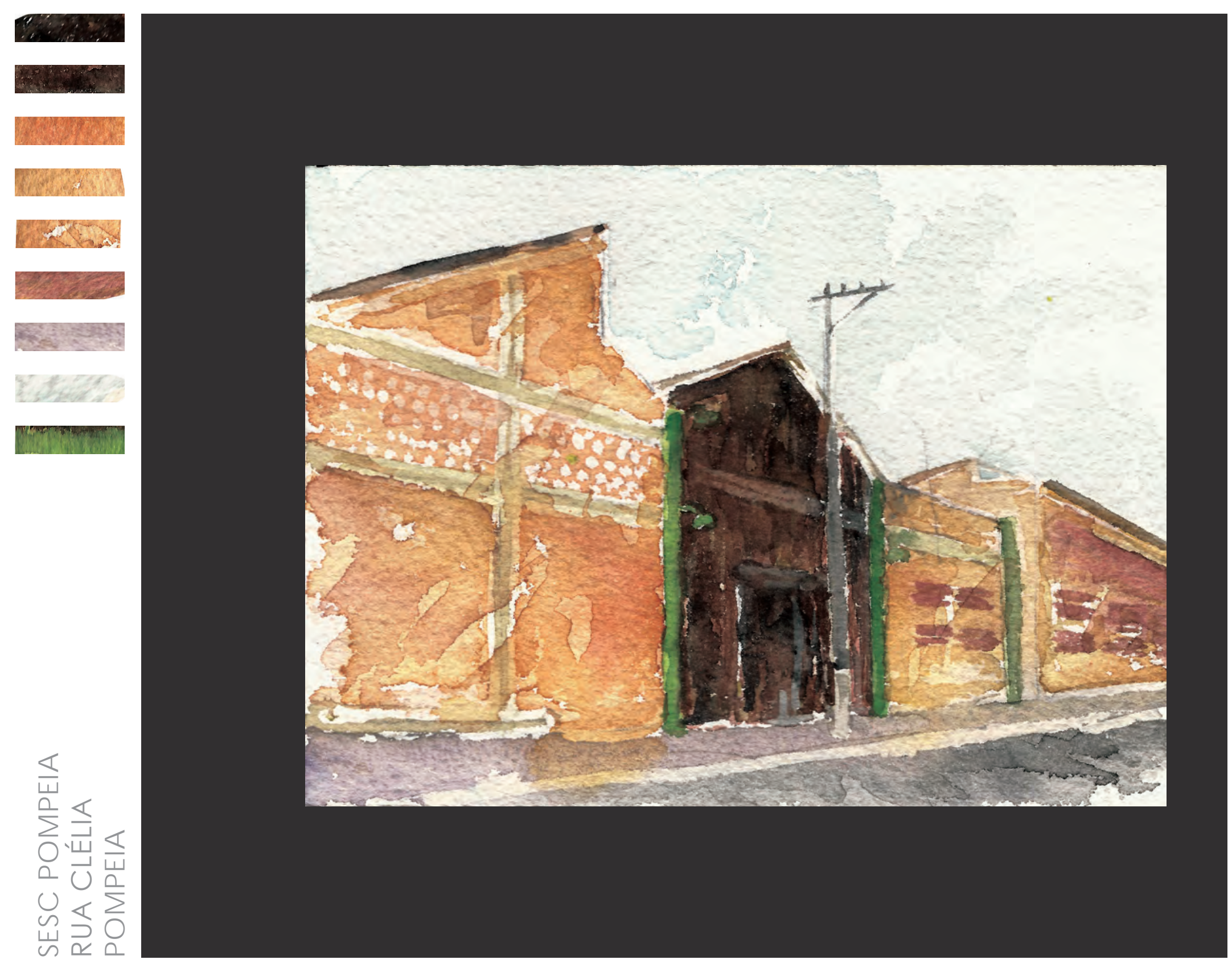




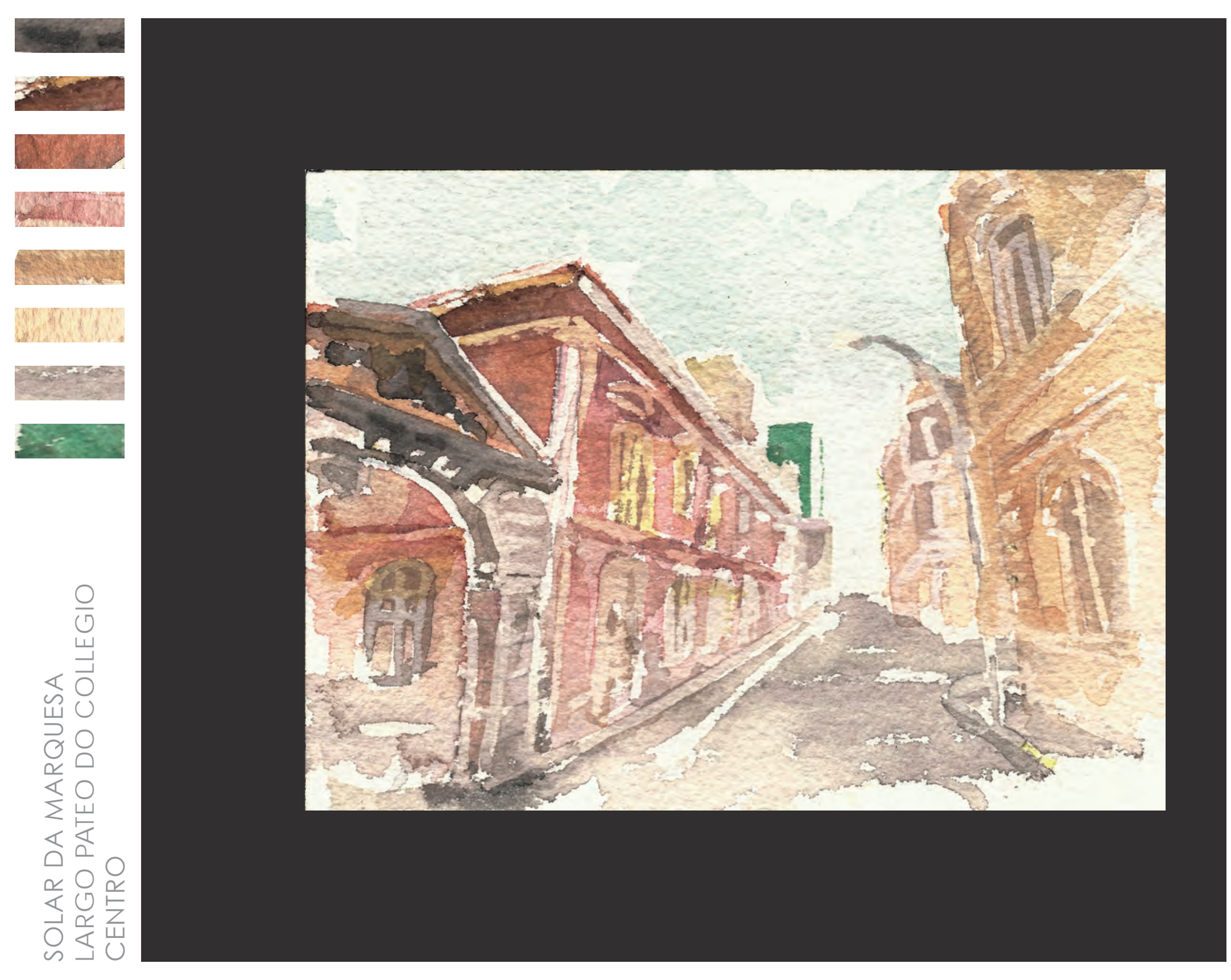




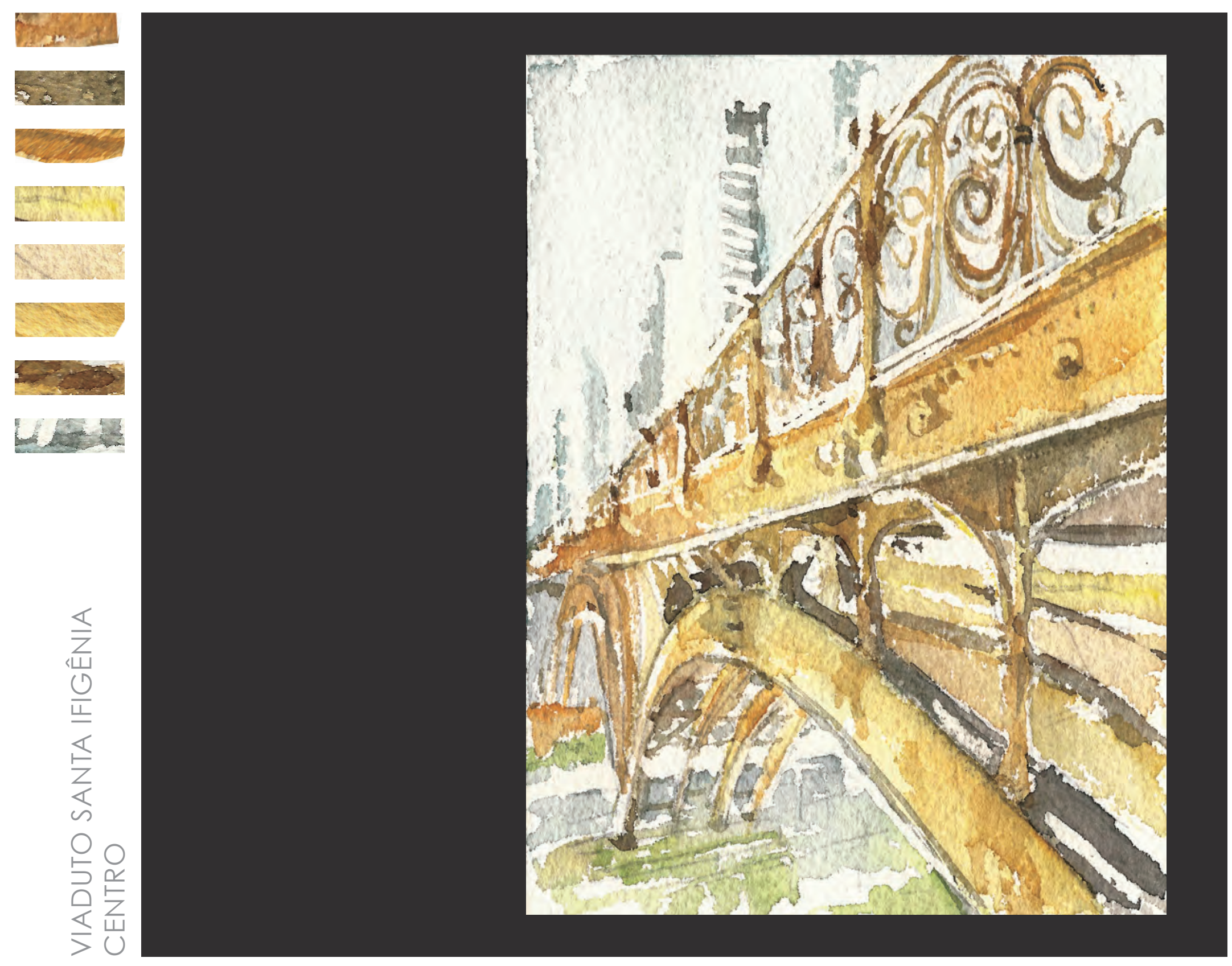




\section{IMPRESSÕES}

Cada época tem sua atitude ótica e, às vezes, em um instante involuntário, pode-se resgatá-lo quando se apresenta pela simplicidade, pela emoção, pelo inconsciente - passando a ter uma significação particular a cada observador. A memória impregnada pela força da cor nos auxilia na organização harmônica do pensamento, do olhar e da emoção. 
"É essa imaterialidade da operação visual que a torna tão propícia ao espírito. Ela prepara os olhos para a transferência do intelecto, começando por usurpá-lo - o pensamento fala com a linguagem do olhar - e terminando por serem usurpados por ele - o espirito dirá que os olhos nã o sabem ver" (CHAUI, 1988, p. 40, in: O olhar).

Segundo Marilena Chauí, a pintura é ruminar do olhar e inspiração, expiração, respiração do ser. A pintura transforma o sensível, processando o visível do visível, em que nos proporciona compartilhar como o pintor o seu simples olhar, quando nossos olhos veem.

“[...] é da natureza de uma foto não poder nunca transcender completamente seu tema, como pode uma pintura. Nem pode um fotógrafo transcender o visual propriamente dito, o que é, em certo sentido, o objetivo supremo da pintura modemista" (SONTAG, 2004, p. 111).

Percebo após algum tempo que os registros são, de certa maneira, tudo aquilo que já se tinha vivido, sentido ou tocado. A cor participa sempre de forma intuitiva e precede sempre à escolha, onde o imaginário toma também corpo ao lado da observação - daí as opções por determinados ângulos, ou horários do dia, ou reflexos para retratar o olhar. A cor estabelece relações explicitas nas imagens, incorporando olhar e peculiaridade dos espaços da cidade.

Na pintura acontece uma tensão entre o documental e o abstrato do trabalho, permitindo à cor a liberdade da linguagem e da sua expressão, em que as relações mais importantes aconteçam justamente entre as próprias cores numa situação relacional que transcende o significado puro e simples delas isoladas. Não se busca o simbólico, mas a energia expressiva da cor, capaz de alertar o olhar e fixar na memória. A aquarela, em específico, trabalhada com agua das de cor, distorcem em certo ponto o espaço registado e, a pesar de poder identificá-lo, as formas se diluem em cor e efeitos da luz que se observa - num ambiente às vezes 
estranho ao nosso olhar, como uma memória distante e esmaecida.

O registro de cores é um recorte deliberadamente pensado, onde a cor não é circunstância casual ou inerente da descrição, porém se manifesta de diferentes formas — na materialidade da superfície do papel, na transparência da cor, do reflexo que proporciona na composição doselementos, na plasticidade do a mbiente observado e retratado, na peculiaridade da poética.

É uma relação ambígua, difícil estabelecer o que antecede: o registro ou o interesse no uso da cor, sobretudo porque o espaço urbano tem seus matizes, ainda que a íntima experiência cromática vivenciada desseslugares seja igualmente importante no registro, ou seja, não podem ser dissociados. As cores nos aproximam da memória e da característica pertencentes à paisagem local, criando um imaginário próprio do lugar, podendo revelarum lapso temporal em que ocorrem as mudanças e o desejo de documentar e preservar a memória. 
PARIE 3 


\section{REPEXõES}

Meu pai se aposentou como gráfico. Quando criança me trazia os bendês (benday) — filmes nos quais imagens seriam retocados, num época que não se tinha scanner e menos ainda Photoshop, todo trabalho era manual e minucioso antes da impressão final. Ele, vindo de uma família de parte veneta de muitos tios pintores, tinha talento e esmero, e de parte andaluz, tinha persistência e crítica ácida — um perfeccionista nos alinhamentos, na identificação das cores e sua composição na indústria gráfica. Trazia-me as provas impressas dos filmes e me testava para que eu decifrasse em CMYK o quanto de ciano, magenta, amarelo e preto teria tal azul daquela prova. A proximidade com este mundo de cores percorreu toda minha vida profissional e me trouxe as mais diversas experiências pessoais, ainda que mais dúvidas sobre sua totalidade e a amplitude da sua extensão de conhecimentos. 
Esta pesquisa é inspirada no desejo de discutir e compartilhar a ímpar experiência cromática de que somos capazes. Utilizando-se de meios simples e intuitivos de capturar a cor no meio urbano que vivenciarmos e sermos capazes de bem reproduzílas em outras situações. A cidade é sempre tema de toda ordem de reflexão - é um campo vasto e gentil às percepções e experimentações. Espero que de alguma forma possa ter instigado o olhar individual e a amplitude da cor.

A cidade, fragmentada, é narrativa de seu tempo, tem como enredo e tessitura a experiência acumulada dos próprios habitantes do lugar - possui a qualidade de manter a tradição e o envolvimento social. Por essa perspectiva, a narrativa articula-se à memória, como preservação de um saber-fazer socialmente constituído e cultivado. "Toda narrativa, como representação do olhar, é carregado de fatores emotivos, quer seja intuitivos ou 'saberes antigos e distantes da nossa cultura atual'" (BENJAMIN, 1996, p. 77).

A essência do lugar não me parece apenas síntese abstrata de fatores concretos da matéria como forma, cor e textura; pois a cada lugar, independente de seu tamanho, no âmbito da rua ou da cidade, associa-se uma imagem e uma sensação, como produtos socia is, decorrentes de intervenções humanas e às associações que se condiciona à memória pessoal e ao repertório de cada um. Cada um põe algo de si mesmo.

Segundo Élide Monzeglio: "O meio ambiente fomece o estimulo sensorial que, a o agir como imagem percebida, dá forma às nossas ideias [...] não determina as imagens, mas possui irresistível poder de despertar sentimentos ao lugar [...] Assim como a forma, a luz-cor associa sentimento que é veiculado pela cor urbana" (MONZEGLIO, 1979, p. 13). 
Conforme a posição da luz, os objetos são realçados, tornando-se evidente que a aparência não é a penas resulta do das propriedades do objeto, mas que depende também de sua relação com o seu entorno e com a luz, o que enrique nossa percepção. A cor torna-se elemento focal na percepção e apreensão de qualidades espaciais, como suporte da imagem formada e de sua expressão que, associada a seu elemento revelador, a luz, denota significados diversos da vivencia histórica, cultural, de tradições ou religiosa.

A cor aplicada enfatiza que o resultado cromático de uma paisagem provém não apenas da razão ou dos atributos físicos da cor, contudo é produto da natureza da luz, do sistema visual e emocional de cada um. Para Cullen, em termos de percepção ambiental, significa dizer que a primeira imagem visual que fazemos é decorrente, em síntese, de sensação de espaço e cor. "A visão tem o poder de invocar as nossas reminiscências, com todo o seu corolário de emoções [...] são aspectos paralelos como este que nos interessam, pois se realmente o meio a mbiente suscita reações emocionais - dependentes ou não da nossa vontade - temos de procurar saber como isso se processa" (CULLEN, 2004, p.10).

O tema da coraplicada é complexo por tratar-se de uma questão relacional e não apenas de cores isoladas, onde a expressividade da cor dependerá das funções que desempenhe. A pintora Fayga Ostrower coloca que o conhecimento quantitativo é supérfluo, porque irrelevante, e nada tem a ver com a expressividade das cores e com a sensibilidade das pessoas. "O importante é entender que com poucas cores básicas - e sempre as mesmas - é possível estabelecer relações diferentes. Essas representam ordenações colorísticas que, por sua vez, correspondem a certas estrutura s espacia is e expressivas"(OSTROWER, 1983, p. 234). 
OLHAR E DESENHO PERCURSOS PELA CIDADE. SÃO PAULO

IMAGENS. CENAS

ÉLIDE MONZEGLIO

"Do vale do Anhangabaú, subindo a escadaria do Largo da Memória. Andando pelo Viaduto do Chá.

É fim de tarde e as luzes se acendem.

Chegando no Largo da Misericórdia, como me oriento, para que lado?

Entrando na Catedral da Sé

O órgão entoando Bach.

Passar pelas fontes da Praça da Sé, sentir o espirro das águas em dia de verão com o sol do meio-dia.

Controlando o vaivém dos meninos de rua nos jardins da Praça da Sé. 
Entrecortando as pessoas na Rua Direita, procurando espaço para caminhare chegaraté a vitrine do anúncio da loja, mas, qual loja? É a do a núncio?

Ver o 'rosa chá' do Prédio Martinelli e jogar o olhar para cima Redesenhando as linhas dosomatos, dasjanelas, do alto do velho arranha-céus e sentir a rua São Bento a seus pés.

Entender as entradas e saídas do Edifício do Correio descendo a Praça Antônio Prado pelo começo da Avenida São João.

Sentir o aroma que vem dos bares e querer um descanso, uma pausa que tem gosto de Cafezinho Paulista.

NOTA: Tentar atravessar as ruas, a sa venidas, esperar abrir o farol das texto parcial apresentado pela autora para a disc iplina Mensagens Visua is Integradas, no curso de pósgraduação

da FAUUSP, em

1994. Cheirar fumaça de ônibus, colocaróculos escuros, andar, andar [...]" 
PROCEDIMENTIOS 


\section{NOTA}

A orientação do prof. Dr. Donato Ferrari foi fundamental no direcionamento das reflexões, sempre me atentando para que eu buscasse uma forma particular de abordar o tema, fundamentadas sobre as minhas próprias experiências com a Cor.

Durante o período de participação em disciplinas do doutorado, tive a oportunidade de cursar disc ip linas que muito me auxiliaram quanto a abordagem da temática:

A Linguagem da Fotografia (CJE 5273), do prof. Dr. Atílio José Avacini - que em saídas fotográficas propostas por São Paulo, enfatizou-se a questão dos trajetos como narrativa das imagens;

Cultura Contemporânea: Estudosem Artes, Design e Arquitetura (AUP 5844), do prof. Dr. Carlos Roberto Zibel Costa - que discutiu através de diversas vertentes a questão da identidade e da memória;

Aproxima ções: a Core outras Leituras (AUP 5884), do prof. Dr. Feres Lourenço Khoury; Reflexões sobre a Cor/Intercambio (CAP 5105), do prof. Dr. Marco Garaude Giannotti e prof. Dr. David Anfam; Core Cidade (CAP 5400), do prof. Dr. Marco Garaude Giannotti e prof. Dr. João Carlos de Oliveira Cesar - que discutiram aspectos variados sobre a Cor, sua leitura, expressão e participação em diferentes contextos. 


\section{PRELÚDIOS}

A dificuldade inicial da pesquisa foi em estabelecer propostas que atuassem no observador, incentivando-o a olhar e perceber a partic ipação cromática, que existe na composição da paisagem urbana da cidade. Parto do pressuposto da existência desta qualidade cromática dos espaços, porém a questão estaria em como demonstrar e torná-la observável.

Houve em partic ulara disciplina A Produção Tridimensional Contemporânea: a Arte da Instalação (CAP 5827), sob orientação do Prof. Dr. Carlos Alberto Fajardo, que nos propunha elaborar uma intervenção ou uma instalação sob a temática da cidade - e que me trouxe desdobramentos e mudanças de atitudes perante a pesquisa.

Após algumas discussões sobre as possibilidades de intervenção, propus o tema: "o que você vê?", a lém de elaborar um protótipo denominado "Olha tónio" (um misto de oratónio, pelo posicionamento do observador; e de observatório, possível pelos diversos orifícios no protótipo). O protótipo tinha a proposta de sercolocado em alguns pontos da cidade e convidarostranseuntes a experimentá-lo.

NOTA: há a síntese do projeto -insta lação na PARTE 4, como anexo.
Qual não foi a minha surpresa que, mesmo exposto em áreas em que os transeuntes eram voltados às artes e arquitetura, utilizavam o aparato para olhar o movimento das pessoas e não o entorno. Com isto, ficou ainda mais evidente que o hábito de olhar, observando nosso meio, não era uma atividade simples, cotidiana. Mesmo conscientes desta proposta, deste chamamento ao Olhar, e nem mesmo frente ao apelo à descrição do que se via, era suficiente à absorção da percepção visual. Haveria a necessidade de um momento de introspecção - que 
talvez somente através do registro auxiliaria na real fixação da atenção aos elementos que nos rodeiam.

Após essas observações, surgiram as duas formas de registro propostas: a da fotografia, muito adequada à narrativa de um percurso, onde se pode obter impressões mais rápidas do que chama a atenção e de sua observação, podendo ainda repetir vários registros a té alcançar a leitura desejada do lugar. A cor depende da luz, e por isto interessava ainda mais que os registros de um percurso fossem elaborados dentro de um mesmo período de luz, de forma que a relação entre as cores fossem mantidas.

E outra, a da aquarela, rea lizada ta mbém no local, total ou parcialmente a pós a notações de valores cromáticos de referência. Por se tratar de uma técnica em que as manchas de cor acontecem nasaguadas, é nec essária uma atenção ma ior para as matizes observadase suas relações - sobretudo sobre sua proporção na composição. Pode-se realizar a aguada a partir dos matizes ma is escuros ou dos mais claros, e há sempre a questão do tempo de secagem que também influencia no resultado final das cores sobre o papel. Realizada com mais tempo e preparo, a técnica possibilita refletir sobre aquilo que se vê da cidade. 


\section{RELATO \\ PROCESSO DE TRABALHO}

Após as pesquisas teóricas em estabelecer a extensão e os limites das formas de registro de imagens, associei o registro fotográfico à identidade, que é muito mais mutante no contexto da urbanidade, e o registro pictórico, que está também associado à memória em sua compreensão e representação aos usuários dos espaços urbanos. Portanto, estabeleci a forma de representação e de linguagens que entendi como adequadas às diferentes situações:

1. Trajeto - para a identidade;

2. Fragmento - para a memória.

Observando-se ao final que as duas linguagens tem suas peculiaridades, contudo por tratarem do mesmo fator de observação, podem se substituir em algumas situações, pois há rebatimento de alguns percepções.

Partiu-se então à visitação livre, com o espírito de flanar pela cidade em bairros e locais préselecionados pelo meu conhec imento vivencial desses lugares, espaços que conhecia porter passado por eles por diversas vezes ou que tinha alguma relação afetiva - pois queria, acima de tudo, testar o quanto se poderia observá-los como expressivos em relação à Cor. Os critérios de escolha dos locais foram pautados também sobre os parâmetros:

1. Grande fluxo de transeuntes - passíveis de passagem e de permanência - onde a interferência fosse ainda mais intensa;

2. Diversidade de funções e atividades - verificando o comportamento do uso da cor em diversas situa ções de uso; 
3. Referenciais às pessoas - que pudessem ser de conhecimento comum, parte do cotidiano.

Através de mapeamentos, se registrou os principais trajetos e marcos de interesse, onde foram feitos os primeiros registros fotográficos como uma pré-seleção, com apontamentos das potencialidades para expressá-los, utilizou-se também de forma primária de registrar rapidamente alguns valores cromátic os por rua, com o auxilio do catálogo de corespara pintura comercial (Suvinil/Coral).

O uso do catálogo de cores foi uma opção para anotações gerais, pois tratam-se de cores utilizadas na pintura de empenas do cenário urbano - não se queria ter um preciosismo no registro exato da cor, mas um referencial, que auxiliaria mais tarde à escolha final dos locais a serem analisados. A praticidade do catálogo está na facilidade em manuseá-lo - colocando - o à frente da visão em direção do que se quer avaliar, e assim observar edifícios à distância; o que um equipamento mais sofisticado e adequado à medição faria somente para objetos próximos e não tão distantes quanto se desejaria à captação da paisagem em sua maior amplitude possível.

Fotografou-se por cerca de dois anos os diversos lugares - sempre atentando à luminosidade e à distorção cromática que deveriam se sobrepor ao interesse formal da arquitetura, estabelecer um ritmo na sequência de imagens, já norteando um contexto urba no que a tendesse o objetivo da pesquisa e apontando questões que seriam futuramente abordadas em relação à composição da cor e à atração do olhar.

Procurou-se seguir certo rigor na captação das imagens, estabelecendo uma metodologia de lidar com a imagem de maneira menos frontal, para conseguir uma perspectiva em que 
mais elementos pudessem ser captados nestas imagens - isto no caso dos Percursos, em que se desejava configurar uma narrativa, uma identidade do lugar. Ao contrário do que ocorreu com o registro pictográfico, em que há sempre um objeto em primeiro plano, uma frontalidade a o objeto, cuja exc eção a contece apenas no registro de áreas abertascomo uma praça, um beco, etc.

Esse aprofundamento da forma de olhar e representar o que observava, permitiu ajustes importantes, que melhor enfatizavam aspectos da cor, dimensões, proporções, enquadramentos e interferências. São imagens que possuem fisicalidade depois de representadas, que tem sentido dentro de um contexto urbano na sua existência real de uma identida de ou de uma memória, mas que passam a serem objetos físicos e não apenas virtuais, que dependem de como seriam representados.

Como acontece em alguns casos de pouca nitidez de alguns objetos representados nas imagens - não nos interessa mais o reconhecimento do objeto em si, ou parte da arquitetura pela forma, mas sim o seu valor cromático, a qualidade da cor que está na composição representada.

Delimitadas as áreas, partiu-se à seleção final das imagens, marcando os trajetos dos percursos e intuitivamente escolhendo os marcos de memória (inclusive com o auxilio da narrativa de moradores mais antigos da cidade, que referenciavam e conferiam legibilidade a escolha de alguns destes objetos de interesse a serem retratados). Durante o processo de registro, identificou-se a questão da temporalidade, quase furtiva no cotidiano - diante de fotos do mesmo lugar, que por vezes passavam pela alteração das fachadas, pela repintura, pelo desgaste natural, ou pela ação depredatória dos transeuntes. 
A luz e a cor, inseparáveis, são enfatizadas na medida do possível em contrastes, buscando sua saturação, enfatizando ainda mais as diferenças tonais, mais do que a pretensão de uma ima gem descritiva, pois a té a descrição se toma sensivelmente individual, onde todo recorte é uma opção particular do que se vê.

Refletiu-se ainda a respeito da retração das figuras humanas nos registros - vejo como elementos transitórios, que pela brevidade do a parecimento não podem ser considera dos como parte da composição para observar a cor do lugar, mesmo em casos de aglomerado de pessoas não há um padrão cromático que possa ser avaliado, portanto, foi considerado como neutro na paisagem mesmo quando registrado nas imagens. Muitas vezes o esvaziamento das ruas não acontece, só se alteram seus persona gens que se tomam meros passantes ou observadores desatentos no momento do registro. 


\section{RELATO \\ MONTAGEM E APRESENTAÇÃO}

Talvez a organização do material e sua reprodução tenha sido a questão mais angustiante durante o processo de apresentação da pesquisa, pois influenciaria a forma de ver de quem - lesse. Após alguns estudos de diagramação, se pensou em apresentar os percursos como na rrativas, onde as imagens a presenta ssem um chamado da atenção e que, no conjunto das imagens daquele percurso, os aspectos da identidade do lugar fossem observáveis.

\section{Para PERCUROS:}

1. Os mapas, disponibilizados pelo site da Google Maps, foram retrabalhados de maneira a somente visualizar os espaços abertos de amuamentos e áreas livres como praças, pátios, monumentos, etc. de uso público. Foi elaborado um texto genérico sobre o bairro, ou sobre parte dele, em que se expõem asobservações relacionadassobre a identidade e aspectos

cromáticos específicos do trajeto e genéricos à região;

2. Alterou-se a escala dos desenhos, para demonstrar o percurso realizado e o ponto das tomadas de imagens registradas - daí nomeando-se os locais registrados. Esta foi uma opção para que houvesse uma menor interferência nas imagens selecionadas;

3. Há ainda uma parte de Impressões sobre o conjunto dos Percursos, em que se pretende evidenciar as qualidades cromáticas. 


\section{Para FRAGMENTOS:}

1. Os lugares registrados através da aquarela foram visitados mais de uma vez, e em alguns casos, os registros refeitos por ocasião de uma melhor oportunidade de retratá-los;

2. A exposição das imagens foi simples, identificando apenas o local e/ou o marco (edifício, espaço, monumento) — optando também pela menor interferência, há uma imagem apresentada por folha - onde a cor é evidenciada e junto há uma escala de cores observáveis (paleta).

3. Nas Impressões sobre Fragmentos, a cor é um dispositivo forte de memória e também passa a ser chave da compreensão dos lugares.

A reprodução das imagens - passando da fotografia para os arquivos do computador, ou da aquarela sendo escaneada para depois tomarem-se arquivo, e ainda trabalhadas para serem impressas, foi um processo trabalhoso e fino ajuste. Procurando-se a melhor maneira de manter os valores cromáticos representados, o mais fidedigno possível — onde alguns verdes teimavam em se transformar em qualquer coisa, menos em verdes dos registros!

O mesmo ocorre na escolha de papéis adequados à impressão — foram feitos testes em papéis porosos de algodão, com e sem brilho, brancos e naturais - até se optar pelo papel espanhol IVOLASER, 190g/m2 (importador Jose Luis Mondran y Cia, S/A de CV - México), impressora digital Xerox duplo color 252/laser, - que mantém apreciável as qualidades de transparência da aquarela e a textura original e rústica do papel tipo Grain Torchon/ Rough (Aquarelle Arches, Movlin, $330 \mathrm{~g} / \mathrm{m}^{2}$ ). Rústica como a própria cidade pode parecer, mas também sensível e transparente, é uma ambiguidade que também se retrata na linguagem.

[Encadernações: costura à mão, capa em tecido Cashmere, tipo Saphir, com película de amido e gravação em clicheria — relevo seco/ hot stamping]. 


\section{REFERÊNCIAS}

NOTA:

a editoração deste trabalho foi realizada por Raquel Vitorelo.

site: www.rvito re lo.com

\section{BIBLIOGRAFIA}

AUMONT, Jacques. A ima gem. Campinas: Papirus, 1995 (p. 230 - 254).

BARTHES, Roland. A câmara clara (trad. Júlio Castañon Guimarães, 4ª.ed.). Rio de Janeiro: Nova Fronteira, 1984.

BATCHELOR, David. Cromofobia. São Paulo: editora SENAC, 2007. 
BAUDELAIRE, Charles. O pintor da vida modema. Sobre a modernidade. São Paulo: Paz e Terra, 2001.

BENJAMIN, Walter. Obras escolhidas III - Charles Baudelaire, um lírico no auge do capitalismo. Trad. José Carlos Martins Barbosa/ Hemerson Alves Baptista. $3^{a}$. ed. São Paulo: Brasiliense, 2011.

Obras escolhidas I - O narrador. Considerações sobre a obra de Nikolai Leskov. In Magia e técnica, arte e politica: ensaios sobre literatura e história da cultura. $7^{a}$ ed. São Paulo: Brasiliense, 1996.

BOSI, Alfredo. O sere o tempo da poesia. São Paulo: Cultrix/ EDUSP, 1977.

CALVINO, Ítalo. As cidades Invisíveis. Trad. Diogo Mainardi. $1^{a}$. ed. São Paulo: Companhia das Letras, 1990.

CHAUÍ, Marilena. Janela da Alma, espelho do mundo. In: NOVAES, Adauto (org). O Olhar. São Paulo: Companhia das Letras, 1988.

CHIJIWA, Hideaki. Color Ha mony: a guide to creative color combinations. Trad. inglesa Keiko Nakamura. $1^{a}$. ed. Cincinnati: Rockport Publishers, 1987.

CULLEN, Gordon. Paisagem Urbana. Trad. Isabel Correia/ Carlos Macedo. Lisboa: Edições 70, 2004. 
GAGE, John. A corna Arte. Trad. Jefferson Luiz Camargo. São Paulo: Martins Fontes, 2012.

HERZOG, Werner. Caminhando no Gelo. Trad. Lúcia Nagib. 2a . ed. São Paulo: Editora Paz e Terra, 2005.

LAGO, André Correa do; LAG O, Beatric e Correa do; SAШES, Marisa Moreira; LORES, Raul J uste; GAMA, Rinaldo; ALVIM, Tomas. Ricardo Legorreta. Sonhos Construídos. São Paulo: BEl Editora, 2007.

MARX, Murillo. Cida de Bra sileira. São Paulo: EDUSP/ Ed. Melhoramentos, 1980.

MERLEAU-PONTY, Maurice. Fenomenologia da Percepção. São Paulo: Martins Fontes, 2011. O visível e o invisível. São Paulo: Perspectiva, 2007.

MONZEGLIO, Élide. Sobre o tema da cor. São Paulo, FAUUSP, 1975.

Cor: Contribuição do Estudo da Cor e sua aplicação na programação de Mensagens Visua is. Tese de doutoramento. São Paulo, FAUUSP, 1972.

OSTROWER, Fayga. Universos da arte. Rio de Janeiro: Campus, 1983. 
PEDROSA, Israel. Da cor à cor inexistente. $3^{a}$. ed. Brasília: Editora UnB/Rio de Janeiro: Léo Christiano Editorial, 1982.

SATRE, Jean-Paul. O sere o nada. Ensa io de ontologia fenomenológica. São Paulo: Vozes, 2005.

SCHULZ, Sonia Hilf. Estéticas Urbanas - da pólis grega à metrópole contemporânea. Rio de Janeiro: LTC Editora, 2008.

SONTAG, Susan. Sobre fotografia. São Paulo: Companhia das Letras, 2004.

VALÉRY, Paul. Degas Dança Desenho. Trad. Christina Murachco/Célia Euvaldo. São Paulo: Cosac \& Naify Editora, 2003.

IMAGENS

\section{Página 16}

KLIMT, Gustav. O beijo (Der Kuss). 1907/8.

Disponível em <http://www.itusozluk.com/gorseller/der+kuss/44149>.

Acesso em 11 agosto 2012.

\section{Página 28}

BARRAGÁN. Capela Tlalpan - Sagrado Coração. México. 
Disponível em <http://www.floornature.com/media/photos/30/4427/wr198_4_popup.jpg>. Acesso em 08 dezembro 2012.

BARRAGÁN. Casa de Barragán. Tacubaya, México.

Disponível em <http://www.arcspace.com/CropUp/-/media/160693/barragan-1.jpg>.

Acesso em 08 dezembro 2012.

\section{Página 30}

Chiapas. México.

Fonte: arquivo de Legoretta,

In: Ricardo Legoretta. Sonhos Construídos (LAGO/outros, 2007, p. 29B).

Chiapas. México.

Fonte: arquivo de Legoretta,

In: Ricardo Legoretta. Sonhos Construídos (LAGO/outros, 2007, p. 29C).

\section{Página 32}

Hacienda, Puebla, México.

Fonte: arquivo de Legoretta,

In: Ricardo Legoretta. Sonhos Construídos (LAGO/outros, 2007, p. 24A).

LEGORRETA. Casa da Cruz, México (2001). 
Fonte: AKG/LatinStock 33 A, Casa Sotogrande.

In: Ricardo Legoretta. Sonhos Construídos (LAGO/outros, 2007, p. 25C).

\section{Página 33}

Marakesh, Marrocos.

Fonte: arquivo de Legoretta,

In: Ricardo Legoretta. Sonhos Construídos (LAGO/outros, 2007, p.16A).

LEGORRETA. Centro de Artes Visuais. Santa Fé, EUA (1999).

Disponível em <http://www.legorretalegorreta.com/centro-de-artes-visuales-de-santa-fe/>. Acesso em 03 agosto 2011.

\section{Página 45}

Alhambra - Granada, Espanha (1854 - 56).

CLIFFORD, Charles.

In: A Câmara Clara (BARTHES, 1984, p.64).

\section{Página 53}

Oxford - Oxfordshire, Inglaterra (visão serial).

In: A Paisagem Urbana (CULLEN, 2004, p.19) 
NOTAS:

IMAGENS DOS PERCURSOS:

Redesenho realizado em editor de imagens.

Disponível em <https://maps.google.com.br/>, versão 2013.

Acessado no período de jan/2013 a dez/2013.

DEMAIS IMAGENS:

acervo do autor -

produzidas entre 2011 e 2013. 
PARIE 4 


\section{ANEXOS}

Os anexos que se seguem são apresentados em dois textos. O primeiro é uma explanação sucinta sobre a Instalação-objeto Olhatório, que referenciou a questão do olhar em PARTE 3 - PROCEDIMENTOS. O segundo texto trata-se de Conceituações sobre a Cor - como um a panhado geral de a pontamentos elementa res que nos conduzem na a ná lise da percepção da Cor e sua importância. Esta parte em especial não deseja dar conta de todo conhecimento teórico do tema, mas servir de direcionamento.

SUMÁRIO DOSANEXOS

$\begin{array}{ll}\text { TEXTO } 1 & \text { Instalação-objeto: O O lha tório } \\ \text { TEXTO } 2 & \text { Conceituações: A Cor } \\ & \text { Introdução } \\ & \text { A cor } \\ & \text { Percepção humana } \\ & \text { Representação gráfica } \\ & \text { Espectrofotometria } \\ & \text { Colorimetria } \\ & \text { Estímulos Sensoriais } \\ & \text { Elementos psic ológic os } \\ & \text { Simbolismo } \\ & \text { Percepção da cor } \\ & \text { Glossário e nomenc la turas } \\ & \text { Referências bibliográficas }\end{array}$




\section{ANEXO . TEXTO 1 \\ INSTALAÇÃO: O OLHATÓRIO}

A CIDADE COMO TEMA. A CIDADE COMO MATÉRIA

O ponto de partida deste projeto foi a cidade.

Buscava-se uma forma de OBSERVAR o espaço urbano - numa tentativa de organizá-lo ou determinar outra leitura que não àquela existente — talvez a mudança de ordens, que levasse o observador a perceber estes espaços de uma maneira fora do usual.

Assim, a Instalação (ou o Objeto) deveria assumir uma escala que diante do limite estrutural, pudesse participar do Espaço e ainda capaz de ser identificado como objeto.

As diversas caminhadas pelos centros mais urbanos e caóticos nos faz perceber que a clareza das formas concebidas, como unidade isolada, não estabelece ligação direta com a cidade — tão cheia, tortuosa, repleta de imperfeições e informações... Somente a composição a torna estética, pelo seu conjunto — mas quase sempre é o peculiar ou o detalhe que confere interesse e graça.

Das imagens vistas, se passou a formar um repertório de fragmentos de memórias e sensações, que não é único mas ímpar - pois cada individuo tem o seu olhar. A estética urbana parece acontecer não apenas na aparente brutalidade, a deselegância quase que traçada, o movimento possível que somente acontece pelo ritmo das inconstâncias das formas.

A peça objeto, como instalação, permite olhar sem ser visto explic itamente, resgua rda-se o observador por um breve tempo. Diferentes ângulos e detalhes, tal qual objeto de vouyer, torna-se foco do olhar alheio, pelo enquadramento casual. A deformidade da imagem proposta, através dos aparatos da instalação, provoca através do estranhamento perante o olhar a esmo, curiosidade necessária à reflexão e recorte com a realidade visual.

A proposta para a instalação partiu desta observação, que temos uma infinidade de informações sobre nosso entorno e em nosso cotidiano, mas em que tudo se banalizou. A questão era pensar a instalação não como algo fechado em si, em um ambiente em que o observador pudesse entrar e algo acontecer, porém o inverso, onde pudesse fazer o percurso contrário: olhar a sua volta - em busca de uma poética e de novas experiências estéticas de reconhecimento do lugar. 
- A R

De $A$

II. $D_{\text {就 }}$ 

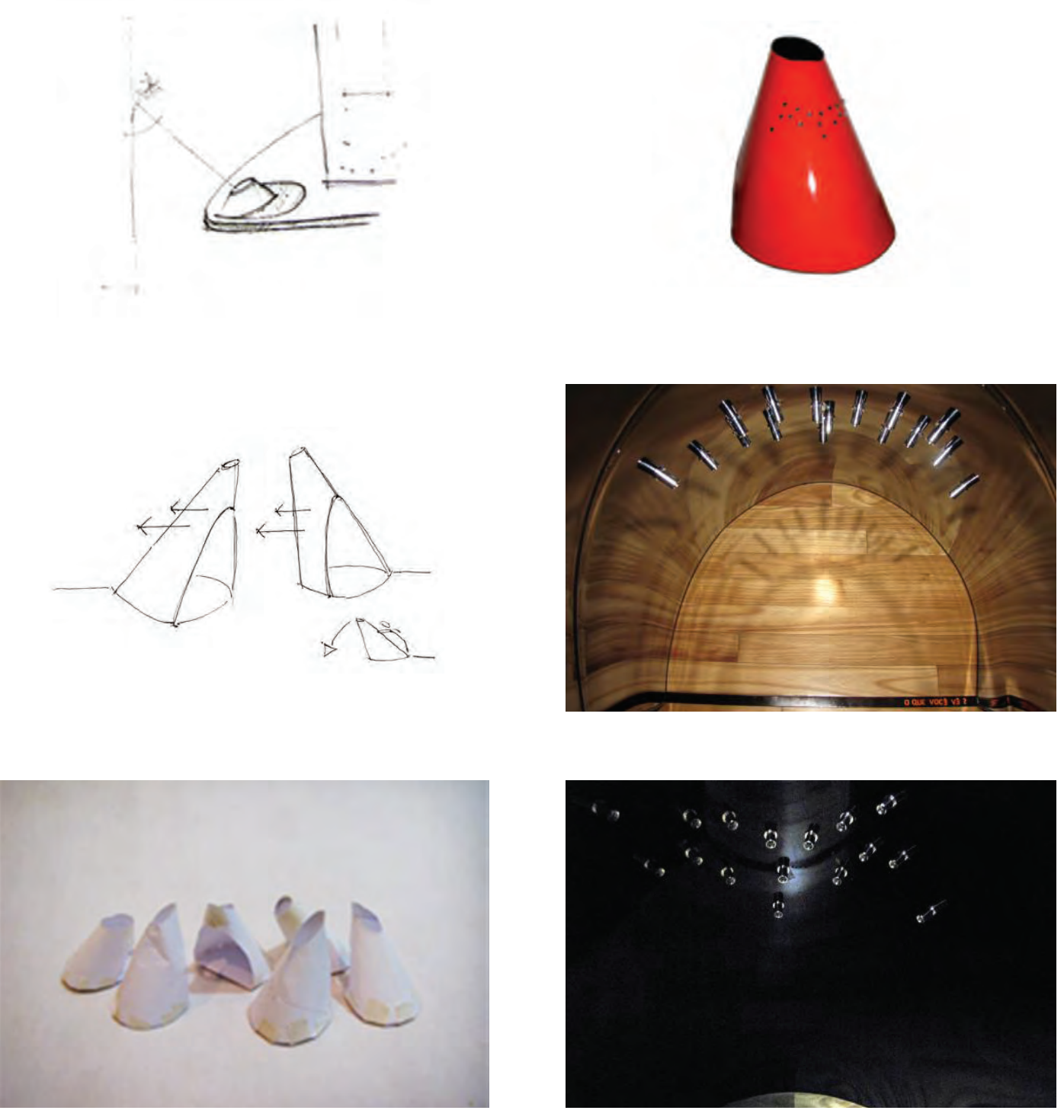
Como incentivar o olhar?

Como tomaro observador um agente ativo?

Quando o meio se torna perceptível?

Olhatório:

local para entrar, olhar e ver.

O que me interessa é mostraro que não se vê.

Olhamos, mas não vemos.
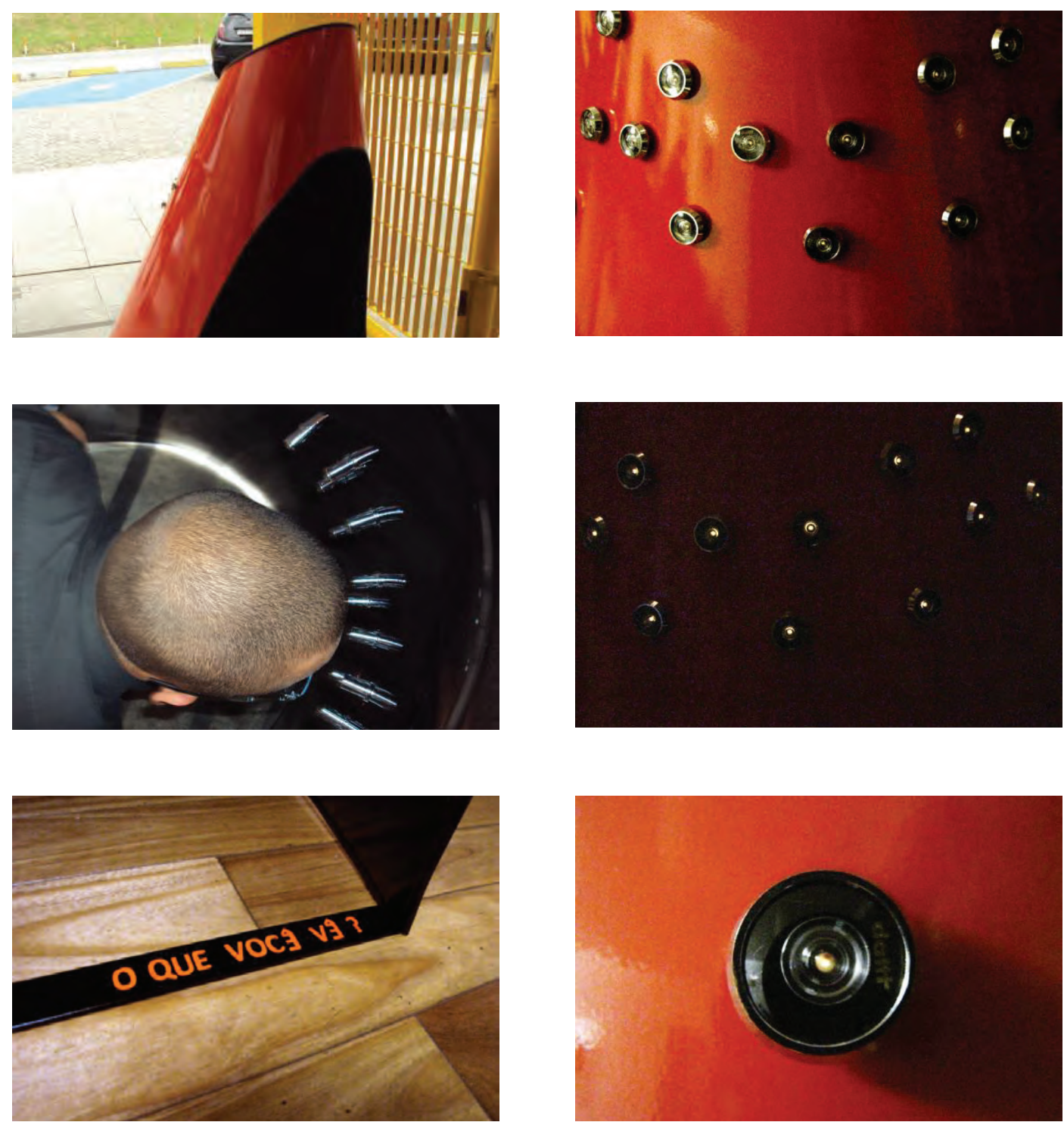


\section{ANEXO . TEXTO 2 CONCETUAÇÕES: A COR}

INTRODUÇÃO

“Em nenhuma outra época a corfoi tão largamente empregada como em nosso século (...) Ao mesmo tempo, que no emprego estétic o da corsurgem novasespecialida desna comunic ação visual. Asmensa gens de todosos tipos, sempre ma is coloridas, ina uguram uma era cultural em que a luz a luc inante e psic odélic a das grandes metrópoles parece ter como único objetivo a poluição visual... Cada cortrazconsigo uma longa história" (PEDROSA, 1982, p. 47).

Atualmente a cor está presente de forma consciente em todos campos da atividade humana, e além de seu poder encantador, com suas sínteses luminosas, tornou-se meio insubstituível de investigação, avaliação e mensuração do que vemos, conhecemos ou imaginamos. O acúmulo de conhecimento nos leva a viver o mais colorido dos tempos, e de desenvolvimento sem precedentes de novos códigos de expressão e comunicação visual. É no mínimo intrigante a afirmação de antropólogos de que nossos anc estra is não distinguiam as cores, mas a penas o claro e o escuro, que aliada a colocação de K. Gerstner que cores são formadas após a nossa consciência, compreende-se que se trata ainda de um processo inacabado, o que dificulta o domínio cromático.

Em contrapartida, a forma é mais evidente de análise, apesar de sua existência ser constatada através da luz, é um elemento mais forte na nossa cultura, no qual expressamos inclusive linguisticamente: transformar, confomar, deformar. O desenho é próprio à forma, pois através dela que apresenta a informação, conteúdo e representação de algo. Pelo princípio da complementariedade, se estabelece que a forma não exista sem cor e vice-versa - seria o mesmo que explicar a complementariedade por matéria e energia que unidas sustem o mundo que conhecemos, por possuírem qualidades diferentes.

"Precisamos saber se além da cor existe algo que possamos ver" (K. Gerstner). Tal questionamento se faz pertinente ao entendermos que as cores são primárias à percepção humana — os elementos que vemos possuem cor. A cor está intimamente ligada à vida por dizer respeito a percepção, a representação de si mesma, por ser a alma da forma e pela capacidade de codificação. Platão diz: "As c ores despertam sensações". E são capazes 
de comunicação por possuírem temperatura própria, porém os efeitos, delas sobre as pessoas, é algo cultural e não natural como foi dito, trata-se acima de tudo de uma noção abstrata, o que reforça o aspecto semiológico.

V. Flusser reconhece que as cores poderiam se tornar a língua universal, por serem tão abrangentes, ao contrário do pensamento linguístico que ser faz necessário a capacidade crítica treinada para o domínio da palavra e do discurso. K. Gerstner faz ainda uma diferenciação importante no tocante a maneira de se relacionar cor e forma quando diz a respeito da topologia — onde as formas são limitadas rigidamente por "linhas pretas", havendo o preenchimento de tais formas; e da tipologia - as linhas não delimitam as cores, mas as cores se delimitam. Segundo a proposta de obter uma visão geral dascorese de sua speculiarida des, a tenta-se a ta iscomportamentos, sempre em vista utilizá-los em favor de maior racionalidade e percepção da cor na paisagem urbana. Afinal, "a maior emoção é a razão" (V.Flusser).

A COR

Os apontamentos que se seguem vão ao encontro de um entendimento genérico de fenômenos básicos que serviram de subsidio a o que se convencionou denominar de Teoria das Cores, atentando-se a certas particularidades da cor e da luz sob a finalidade estética.

Exercer integralmente o controle sobre as transformações das cores — o que Pedrosa chama de mutações cromáticas - , é base de toda harmonia cromática, extraindo daí a variável dose desejada de lirismo existente na pureza da linguagem intima da cor, através do conhecimento lógico. Desde Leonardo da Vinci, vem se demonstrando que as cores se transformam em presença uma das outras e, já o momento se exige o manuseio consciente de tais metamorfoses para o beneficio de seus observadores. Contudo, é adequado lembrar que há além de simples meios materiais empregados, outra cor implícita no corpo material da cor, a cor de sua própria essência.

Pedrosa faz alusão a cores de contrastes, em que sobre um fundo branco, ou neutro homogêneo, sem suporte químico, obtém-se a coloração complementar (inexistente) da cor dominante pintada, perceptível ao primeiro contato visual, sem necessidade de saturação retiniana, e detectável por qualquer câmara fotográfica - provando assim o caráter mutável e relativo dos fenômenos cromáticos que Goethe nos coloca. 
Os fundamentos do domínio do fenômeno da cor inexistente, apoiando-se nos elementos essenciais enunciados por Da Vinci, Scheffer, Runford, Hauy, Goethe, Maxwell e Einstein, diferem, porém em vários pontos das conclusões emitidas pelo químico francês Michel-Eugène Chevreul em seu livro da Lei do Contraste Simultâneo das Cores, em que explica: variando a qualidade, a quantidade, a forma e o posicionamento das áreas coloridas em termos de organização e relatividade, uma determinada cor pode produzir a sensação de sua cor complementar em diversos graus de intensidade. Pode produzir a sensação de outras gamas de sua própria cor, ou ainda, de forma mais surpreendente: a própria cor pode transformar-se em sua cor contrária, complementar.

Os fenômenos cromáticos oriundos das cores de superfície são regidos pelos índices de refletância das substancias coloridas (cor pigmento), que variam bastante. Por esta razão, as cores do espectro não produzem suas complementares com o mesmo índice de visibilidade, nem os discos de Newton pintados com cor pigmento, postos em rotação, produzem o branco almejado. Além da análise da diversidade na composição atômica que caracteriza as cores pigmentos no fenômeno cromático por refletância, ocasionado pela absorção, reflexão ou refração dos raios luminosos, é de primordial importância considerar a qualidade da composição tricromática da luz incidente.

Tais observações referentes ao conjunto destes elementos, ao criar a possibilidade do domínio sobre o fenômeno da cor inexistente, permitiram também a sistematização dos dados que influem nas cores induzidas e nas relações gerais que regem as mutações cromáticas. Portanto, tem-se por Cor Inexistente, denominação de Pedrosa, a cor complementar formada de entrechoques de tonalidade de uma cor levada ao paroxismo por ação de contrastes, cuja aplicação prática advém dos estudos do efeito da percepção visual de cores denominadas cores fisiológicas por Goethe, e de cores de contraste pela Comissão Internacional de lluminação.

PERCEPÇÃO HUMANA

Partindo da realidade física, não se pode negar a existência objetiva dos componentes da luz branca, nem tão pouco esquecer que esses componentes só criarão a sensação da cor em determinadas condições. E tais condições, por mais variáveis, serão sempre expressões de quantidade de sombras. 
Apesar de que na física a sombra não contar e ser encarada apenas como diminuição ou ausência de luz, tanto para a fisiologia como para a psicologia e a estética, sua importância sempre rivalizou com a própria luz na avaliação dos fenômenos cromáticos — daí a pertinência da afirmação de Goethe de que "toda cor tem por origem uma luz e uma não luz". A visão difere sensivelmente de um individuo para outro, quando se toma por base um grande numero de testes. Além das diferenças naturais, a percepção varia num mesmo individuo em função de seu estado fisiológico. O estado psíquico, a fadiga, a debilidade e a ingestão de certas drogas alucinógenas podem causar essas variações ou distúrbios, motivando uma hipersensibilidade à cor. Segundo A.Keys (The Biology of Human Starvation), "Sua percepção não está limitada ao que é biologia ou socialmente útil". As disfunções relativas à percepção da cor começaram a ser estudadas a partir das teses de J.Dalton (físico, químico, biologista e naturalista), que analisando inicialmente as distorções de cores de que padecia, determinou as causas da deficiência denominada daltismo.

Contudo, é importante observar que as diferenças de percepção, não podem ser confundidas por diferenças de nomenclatura, como no caso da descrição das cores do arco-íris por falantes de línguas naturais diferentes na recriação desta realidade — onde o falante do português vale-se sete nomes para designar o espectro solar, um falante do inglês se vale de seis e, um falante do bassa (língua indígena da Libéria, África) se vale de dois. É claro que a diferença no modo de dividir o espectro não corresponde a nenhuma diferença na capacidade visual desses povos para perceber as cores, mas tão somente a uma diferença no modo de representa-las, através da sua língua.

\begin{tabular}{|c|c|c|}
\hline PORTUGUÊS & INGLÊS & BASSA \\
\hline Roxo & \multirow{2}{*}{ Purple } & \multirow{4}{*}{ Hui } \\
\hline Anil & & \\
\hline Azul & Blue & \\
\hline Verde & Green & \\
\hline Amarelo & Yellow & \multirow{3}{*}{ Zza } \\
\hline Laranja & Orange & \\
\hline Vermelho & Red & \\
\hline
\end{tabular}

REPRESENTAÇÃO GRÁRCA 
As primeiras tentativas no sentido de se conseguir uma definição quantitativa das cores se devem a Leonardo da Vinci. Na impossibilidade de aferir a luz, ele improvisou o célebre método das colheres com tinta, para medir a quantidade de cor-pigmento que refletia a luz colorida. Os resultados foram insatisfatórios, mas a ideia da viabilidade da mensuração das cores estava lançada. Para se estabelecer um sistema de medidas, o principal obstáculo residia na falta de uma unidade referencial, bem como na inexistência de conhecimento da parte como o todo. Tais elementos, porém seriam fornecidos por Newton, e um longo caminho haveria de ser percorrido para a elaboração de atlas científicos que padronizariam as cores.

\section{ESPEC TROFOTOMEIRIA}

É o processo usual de análise de luzes homogêneas. As primeiras indicações seguras para a criação do método datam da época de Newton. Presentemente, são vários os aparelhos usados para a aferição dos matizes do espectro, destacando-se o espectroscópio e o espectrofotômetro.

O primeiro aparelho possui comumente um anteparo com uma fenda localizada no foco de uma lente por onde passa a luz (matiz) a ser analisada, e nele a avaliação da imagem colorida é feia pelo olho humano. Já o segundo, desdobramento do primeiro, compara-se de maneira mecânica às intensidades das radiações simples de sua fonte, constituindo-se da combinação de um monocromador e de um fotômetro; o processo típico de espectrofotometria consiste em dispersar os componentes da luz branca e então, isolar uma das faixas coloridas por meio de uma lâmina com uma fenda.

A luz da faixa selecionada, passando através dessa fenda, é dividida em dois raios, um dos quais cai sobre a amostra que está sendo estudada, e o outro numa superfície branca comum. A branca comum será proporcionalmente menos luminosa, e a proporção de luminosidade é facilmente encontrada por qualquer técnica fotométrica adequada. O processo é repetido várias vezes, até que a amostra tenha sido submetida a exame com todas as faixas coloridas do espectro. Desde 1928, o Instituto de Tecnologia de Massachusetts utiliza os fototubos ou espectrofotômetros criados por A.C.Hardy para substituir o olho humano, automatizando o método de análise de cores. O emprego desses aparelhos em várias indústrias levou ao reconhecimento formal do espectrofotômetro como o instrumento básico na padronização fundamental da cor. Atenta-se ainda para a existência de outros sistemas de medição e registro de composição das cores e suas características. 


\section{COLORIMEIRIA}

Para a discrição de superfícies iluminadas por luzes compostas, com comprimentos de onda heterogêneos, a espectrofotometria revelou-se insuficiente. A análise de tais superfícies e das luzes que as iluminam é feita pelo processo de Colorimetria. Os estudos iniciais de Maxwell, Gassmann e Helmholtz, visando a determinação de um observador padrão, personagem fictícia, criada com a média das observações de um grande grupo de pessoas normais em determinadas condições de iluminação, possibilitaram os êxitos das novas pesquisas de Wrighr e Guild, cujos índices indicados foram adotados pela Comissão Internacional de iluminação. Apesar de fundamentar-se na observação humana, a colorimetria, não considera as diferenças de percepção da cor, tão variáveis entre indivíduos. Sua função é determinar as diferentes composições físicas da luz, que provocam as sensações coloridas.

Os primeiros teóric os de colorimetria estã o liga dos aos do is enuncia dos bá sic os das leis de Gassmann:

1. a luminância de uma mistura é igual à soma das luminâncias das cores componentes;

2. quando duas amostras luminosas produzem a mesma impressão de cor, esta igualdade de impressão permanece inalterável, se multiplicarmos ou dividimos cada uma delas por um mesmo número.

A padronização aceita mundialmente para a colorimetria é dada por um quadro chamado "Tabela dos Estímulos Tricromáticos do Espectro", adotada pela Comissão Internacional de lluminação (1931). Pela variação de quantidade de cada uma das três cores primárias: $X$ - vermelho; $Y$ - verde; $Z$ - azul.

Em uma amostra a ser examinada, determina-se a sua composição tricromática, dessa forma, para comprimento de onda $(\mathrm{m} \mu)$ há uma quantidade de X, Y e Z na mistura que tem sua correspondência na tabela.

ESTIMULOS SENSORIAIS

A sensação colorida é produzida pelos matizes da luz refratada ou refletida pela substância. Comumente, emprega-se a palavra cor para designar esses matizes que funcionam como estímulos na sensação cromática. É neste sentido que a usamos aqui ao falar de estrutura da cor. Com base no esquema de Goethe, dividem-se as cores ou matizes (estímulos) em três categorias: estímulos fisiológicos, físicos e físico-químicos.

O que caracteriza o estímulo fisiológico é a sua integração com a sensação, pelo fato de ser originado fisiologi- 
camente, podendo ser gerado por uma excitação mecânica ou formado por excitação subjetiva da retina. 0 estimulo físico é o emitido por uma fonte energética diretora (luz colorida), ou por dispersão dos raios luminosos da luz branca. Nos estímulos físico-químicos, a natureza e a organização dos átomos nas moléculas é que determinam a cor percebida nas substâncias. Como a coloração dos corpos é devida à absorção dos elétrons em torno do núcleo dos átomos, que forma um campo eletrônico carregado positivamente. Portanto, a cor de um corpo é condicionada, de uma parte, pelo campo eletrônico, ou núcleo atômico, e de outra, pela quantidade de elétrons e pelas dimensões de suas órbitas.

\section{ELEMENTOS PSCOLOGICOS}

O crescente interesse pela Psicologia demonstrado pelos tradic ionais estudiosos da cor (pintores, programadores visuais, físicos, químicos, fisiologistas, etc.) corresponde à seriedade com que os psicólogos analisam também os fenômenos objetivos referentes à cor. E para o estudo da cor, a parte da Psicologia que mais interessa é a experimental, por revelar as implicações sensoriais num encadeamento analítico controlado, com base em observações, experiências e deduções na manipulação das reações de organismos complexos, homens e animais, face às condições do meio que os cerca. O fisiologista e psicólogo W.Wundt estabeleceu definitivamente a autonomia da Psicologia Experimental. Dentre seus alunos, destacou-se B.Bourdon, cuja pesquisa da percepção visual do espaço trouxe os elementos básicos para a compreensão da estrutura e localização espacial dos corpos.

Estudando a percepção sensorial, ao mesmo tempo, que Helmholtz, Wundt definiu a distinção entre Sensação simples resultado da estimulação de um órgão sensorial —, e Percepção — tomada de consciência de objetos ou acontecimentos exteriores. Na análise experimental dos processos superiores (memória, natureza de imagens mentais, imaginação, faculdade de compreender, sugestibilidade, sentimento estético, sentimentos morais, etc.), considerou os fatos psicológicos como unidade firmemente estruturada e não como simples justaposição de elementos. Coube ao filósofo alemão H.Ebbinghaus sistematizar o estudo dos processos superiores, tomando por base a memória, a partir dos domínios da sensação e da percepção. Ao mesmo tempo em que realiza os trabaIhos mentais referentes à inteligência. Esses estudos e experiências terminam por ressaltar determinados índices de relação entre a percepção e a inteligência, e vice-versa. Perceber mais, e ver mais, passa a ser sinônimo de maior inteligência. 
Desde a primeira década do século 20, a Psicologia encaminha-se para o estudo dos problemas relativos à totalidade psíquica, segundo o princípio de que a potência (funcionalidade) da forma não depende da simples particularidade e número de seus elementos construtivos, mas de sua estruturação, uma vez que qualquer troca de situação na organização da forma origina outra, criando nova situação. O princípio fundamental comum a todas as correntes psicológicas gestaltistas é o reconhecimento do valor científico, explicativo e heurístico da aplicação das noções dos fenômenos psicológicos. De forma indireta e contraditória, o maior suporte recebido pelo estruturalismo provém do gestaltismo, que se generalizou como método de elaboração das artes visuais contemporâneas.

Na utilização estética - eliminando o caráter extremado do anti-sociologismo, que procura diminuir a importância da experiência acumulada - a corrente gestaltista é a que exerce maior atração aos atuais comunicadores que utilizam a forma e a cor como meio de expressão, por centralizarem seus esforços no conhecimento da funcionalidade dos elementos estruturais. Perceptivamente, há certa analogia entre os padrões da cor e os da forma: a alteração por acréscimo, diminuição ou mudança de posição de uma cor em relação ao conjunto altera também o significado da estrutura. O que é necessário levar em consideração, com referencia à cor, é que sua capacidade de influência psíquica tende sempre mais para os aspectos emotivos, ao passo que a forma é predominantemente lógica. Assim, como a forma só é percebida em razão de uma diferença de cor ou de luminosidade dos campos que a define, a capacidade expressiva e comunicativa da cor só aparece através da forma (tamanho, configuração da área, repetição, contraste, semelhança, proximidade e combinação), atingindo seu maior grau de eficiência quando completa ou reforça mensagem contida na forma.

Na análise psicológica, o contraste simultâneo de cores pode encerrar determinadas ilusões sensoriais de índices tão elevados quanto ao das ilusões óptico-geométricas. Em toda a sua história, a comunicação sempre se valeu de símbolos; os sinais sonoros, visuais ou gestuais, gerados de memorização das formam, terminam por constituir códigos que por sua vez, geram os símbolos, que podem ser formados por um ou vários sinais. Por isso, a constatação de que todo pensamento expresso é sempre simbólico em maior ou menor escala, devido à impossibilidade de representação de todos os componentes do objeto comunicado.

Para representar ideias, situações e objetos cada vez mais complexos, os comunicadores procuram aperfeiçoar 
seus códigos no sentido de uma maior clareza de expressão e de comunicação, possibilitando a criação de símbolos tão desenvolvidos que chegariam a rivalizar com a fotografia e com a descrição analítica. Mas a eficiência desses símbolos nunca esteve na fidelidade da representação, e sim na valorização de ceras características do objeto representado, segundo certas necessidades ou exigências do público a que se destinavam.

Com as devidas variantes, o processo de apreensão de uma estrutura qualquer guarda certa analogia com o fenômeno de impregnação de qualidade que a experiência atribui à forma. Segundo Benussi, as ilusões ópticogeométricas são fenômenos pouco sensíveis à influencia da vontade. Não se revelam permeáveis pelo fator exercício, no sentido de serem reduzidos através de treinamento. A repetição da vivência de um modelo frequentemente reforça a sua assimilação distorcida. Como no caso das ilusões óptico-geométricas, ocorre o mesmo com os elementos bem estruturados. A primeira impressão permanece e ainda é capaz de influenciar as impressões seguintes, se trata de elementos estrutura is semelhantesa os contidos na boa forma. A qualidade empresta a estes elementos, quando participam de uma estrutura determinada, tende a impregna-los de conteúdo, podendo sozinho expressar o todo. Os demais somente serão reconhecidos em organização de subestruturas.

Para Wertheimer, nossa capacidade perceptiva se subordina a um fator básico, denominado pregnância, que significa boa foram ou forma potente e funcional. A pregnância resulta de alguma característica dos elementos formais que poderiam ser sistematizados em: proximidade, semelhança, movimento, boa continuação e destino comum. O princípio geral que rege a organização das imagens, tanto sonoras como visuais, está na combinação numa estrutura de elementos, guardando determinadas relações.

Proximidade: várias estruturas encontram sua característica neste fator e, que depende da disposição de elementos. Sendo muito versátil é possível observar inúmeras subestruturas contidas numa estrutura, de acordo com a natureza e a quantidade de elementos.

Semelhança: numa arranjo, a primeira vista podem saltar um tipo de estrutura e, reforçando o fator Semelha Ca, tem-se predominância visual de outra forma; somente com algum esforço, é que se nota o arranjo anterior formado pelos mesmos elementos. Neste caso, o fator experiência tem grande influência - quem tenha visto o primeiro arranjo perceberá com menor esforço o segundo.

Movimento: o mais contraditório e rico de possibilidade de expressão e comunicação. Nas artes visuais, enten- 
de-se por movimento a característica que indica a orientação das linhas de força (deslocamentos no espaço ou transformações), em se tratando de estruturas estáticas - movimento virtual ou ilusório. O movimento liga-se a ideia de ritmo e obedece a certas leis de orientação de suas linhas estruturais, criando as mais diferentes sensações ao observador.

Continuidade ou boa continuação: quando os elementos de certas estruturas apresentam um destino comum, como no caso de fios retorcidos, ou ainda formas precisas que indicam a direção dos segmentos.

Tendência à complementação: propriedade que tem certas formas de induzirem o espírito a complementar o fechamento de uma estrutura fortemente esboçada; assim, não se vê uma série de elementos, mas uma grande estrutura, como figura única, formada por eles.

SIMBOUSMO

Em todas as épocas, as soc ieda des orga niza das sempre tiveram seus códigos completos, ou determina dos elementos de uma simbologia de cores, atribuindo-lhes frequentemente caráter mágico. A variedade de significados de cada cor, ao longo dos tempos, está intimamente ligada ao nível de desenvolvimento social e cultural das sociedades que os criam.

Os diversos elementos da simbologia da cor, como em todos os códigos (visua is, gestua is, sonoros ou verba is), resultam da adoção consciente de valores representativos, designativos ou diferenciadores, emprestados aos sinais e símbolos, que compõem tais sistemas ou códigos. Com efeito, o que dá qualidade e significado ao símbolo é sempre sua utilização, por isto a criação dos símbolos mais significantes e duráveis é em geral, ato coletivo de função social, para satisfazer necessidades de representação e comunicação.

Embora de maneira bem mais complexa e sutil, o mesmo ocorreu a respeito da cor. Pode-se dizer que a simbologia da cor nos povos primitivos nasceu de analogias representativas, para só depois, por desdobramentos comparativos, atingiu um nível de relativa independência, que corresponde a estágios mais elevados de subjetividade. Historicamente, muitos dos significados das cores guardam o sentido original, enriquecidos com a evolução espiritual dos povos. A cada nova sociedade, os símbolos tornaram-se mais requintados e abstratos acompanhando de perto o voo da fantasia e das aspirações humanas. 
O significado das cores nunca contou com uma vida autônoma, que iniciasse e terminasse o seu ciclo de ação no próprio âmbito das ideias. Ao contrário, as ideias originadas por certos estímulos exteriores só conseguiram transformar-se em símbolos, no retorno ao mundo objetivo, quando testadas pela prática. Decorre daí a importância do símbolo na origem e veiculação de conceitos, base de sua integração nos variados elementos da superestrutura social. Mas essa integração só se realiza quando o símbolo expressam realidades que satisfaçam necessidades subjetivas.

Como em todos os métodos de averiguação psicológica, esbarra-se aqui também, com a contra dição entre influências coletivas como expressão mais nítida das imposições sociais e as particularidades individuais. A opção exclusiva por apenas um dos elementos da contradição é que tem causado a ineficiência da maioria dos sistemas organizados para detectar o gosto estético, inclusive o gosto predominantemente por determinadas cores.

Já nas grandes superfícies coloridas ambientais o fenômeno é invertido: as cores, ao refletir os raios luminosos, agem como refletores sobre o ser humano, dando-lhe um banho de luz da mesma forma que a fonte energética primitiva (o Sol ou outro qualquer foco gerador de luz). A diferença é apenas quantitativa, devido a perda de energia provocada pelos efeitos de absorção e dispersão. As superfícies polidas, principalmente os espelhos, podem realizar um banho de luz com a energia luminosa quase integral, ou até mesmo aumentar sua potência, quando providos de lentes de aumento, como no caso das baterias térmicas solares.

Modema mente, o reconhec imento de que a coré tão somente uma sensa ção coloca-se no campo dasespeculações psicológicas, possibilitando o aprofundamento do estudo das relações entre os estímulos e componentes fisiológicos, para maior conhecimento a dados sensitivos e perceptivos e sua influência nos reflexos conscientes de inconscientes do caráter emocional e moral.

O estudo da projeção da personalidade humana, através de sua preferência ou gosto por determinadas cores, poderá vir a serde grande valia para o conhecimento de áreas da personalidade individual, desde que vencidas as barreiras de uma aplic ação mecânica, de um método que deve serantes de tudo, instrumento de pesquisa, fornecendo novos caminhos para o levantamento da complexidade do psiquismo humano nessa área, plasmado por uma utilização cromática milenar em que se misturam buscas, equívocos e acertos. 
A cor é tida conceitualmente como não tendo existência material: é apenas sensação produzida por certas organizações nervosas sob a ação da luz - mais precisamente, é a sensação provocada pela ação da luz sobre o órgão da visão. Seu aparecimento está condicionado, portanto à existência de dois elementos: a luz (objeto físico, agindo como estímulo) e o olho (aparelho receptor, funcionando como decifrador do fluxo luminoso, decompondo-o ou alternando-o através da função seletora da retina). Em português, o melhor termo para essa característica do estimulo é Matiz, diferenciando-a da sensação denominada cor. Em linguagem corrente, em quase todos os idiomas, a palavra cor designa tanto a percepção do fenômeno (sensação) como as radiações luminosas diretas ou refletidas por alguns corpos (matiz ou coloração) que o provocam. Os estímulos que causam as sensações cromáticas estão divididos em dois grupos: o da cor-luz e o da cor-pigmento.

Cor-luz, ou luz colorida, é a radiação luminosa visível que tem como síntese aditiva a luz branca. Sua melhor expressão é a luz solar, por reunir de forma equilibrada todos os matizes existentes na natureza. As faixas coloridas que compõem o espectro solar, quando tomadas isoladamente se denominam luzes monocromáticas.

Cor-pigmento é a substância material que conforme sua natureza, absorve, refrata e reflete os raios luminosos componentes da luz que se difunde sobre ela. É a quantidade da luz refletida que determina a sua denominação. O que faz com que chamemos um corpo de verde é sua capacidade de absorver quase todos os raios da luz branca incidente, refletindo para nossos olhos apenas a totalidade dos verdes.

O fenômeno da percepção da cor é bastante mais complexo que o da sensação. Se neste entram apenas o elementos físicos (luz) e fisiológicos (o olho), naquele entram, além dos elementos citados, os dados psicológicos que alteram substancialmente a qualidade do que se vê. Pode-se citar o caso do lençol que nos parece branco quando iluminado por luz incandescente (amarela) como por luz de mercúrio. Na maioria das vezes não entendemos para a diferença da coloração e continuamos a considera branco o lençol, por uma codificação do cérebro, que incorpora aos objetos, como uma de suas características físicas, a cor apresentada por eles quando iluminados pela luz solar, transformado em valor subjetivo as cores permanentes dos corpos naturais.

Na percepção distinguem-se três características principais que correspondem aos parâmetros básicos da cor: matiz (comprimento de onda), valor (luminosidade ou brilho) e croma (saturação ou pureza da cor). Apesar da 
identidade básica de funcionamento de elementos no ato de provocar a sensação colorida (os objetos físicos estimulando o órgão visual), a cor apresenta uma infinidade de variedades, geradas por particularidade dos estímulos, dizendo mais respeito à percepção do que à sensação. Resumidamente, segundo suas características e formas de manifestação, adotou-se a classificação e nomenclatura das cores que se segue:

\section{GLOSSÁRIO E NOMENCLATURAS}

[NOTA: REPRODUÇÃO DE TERMOS COPILADOS DE DIVERSOS AUTORES E TEXTOS]

Cor Geratriz ou Primária - é cada uma das três cores indecomponíveis que, misturadas em proporções variáveis, produzem as cores do espectro. Para cor-luz, as primárias são vermelho, verde e azul-violetado e, a mistura das três luzes coloridas produz o branco, denominando-se o fenômeno síntese aditiva. Para substâncias corantes opacas (cores-pigmento, às vezes denominadas cores de refletância ou cores-tinta), as cores indecomponíveis são o vermelho, o amarelo e o azul, a mistura dessas produz o cinza neutro por síntese subtrativa. Para a cor-pigmento transparente, ou por transparência em retículas, as primárias são o magenta, o amarelo e o ciano, e a mistura dessas cores também produz o cinza-neutro por síntese subtrativa.

Cor Complementar - são aquelas cuja mistura produz o branco. Segundo Helmhotz, excluindo-se o verde puro, todas as demais cores simples são complementares de outra cor simples, formando os seguintes pares: vermelho/ azul-esverdeado, amarelo/anil e azul/laranja.

Cor Secundária - é a cor formada em equilíbrio óptico por duas cores primárias.

Cor Terciária - é a intermediária entre uma cor secundária e qualquer das duas primárias que Ihe dão origem.

Cores Quentes - são o vermelho e o amarelo, e as demais cores que eles predominem.

Cores Frias - são o azul e o verde, bem com as outras cores predominadas por eles. Os verdes, violáceos, carmins e uma infinidade de tons poderão ser classificados como cores frias ou quentes, dependendo da percentagem de azuis, vermelhos e amarelos de suas composições. Além disso, uma cor tanto poderá ser fria como quente, dependendo da relação estabelecida entre ela e as demais cores de determinada gama cromática. Um verde médio, numa escala de amarelos e vermelhos, parecerá frio. O mesmo verde médio, frente a vários azuis, parecerá quente.

Cor Natural - é a coloração existente na natureza.

Cor Aparente ou Acidental - é a cor variável a presenta da por um objeto segundo a propriedade da luz que o envolve ou a influência de uma cor indutora. Nessa indução reside a essência da beleza cromática. Em certa 
medida, podemos classificar como indução as manifestações dos contrastes simultâneos de cores, das mutações cromáticas e do fenômeno da Cor Inexistente.

Cor Retinada - é a cor caracterizada pela maior participação da retina em sua produção, transmitindo ao cérebro impressões que retêm, alteram, sintetizam ou totalizam os efeitos de deslumbramento e as sensações coloridas produzidas por pressão à base do globo ocular, etc.

Cor Irisada - é a que apresenta fulgurações análogas às cores espectrais, comuns nas asas de borboletas e nas refrações de um modo geral.

Cor Dominante - a que ocupa maior área da escala em determinada relação cromática.

CorLocal - conjunto de dadose c irc unstancia is a cessónios que, numa situa ção caracteriza o lugare o tempo (por exemplo, numa obra de arte).

CorCrua - a cor pura, que não apresenta gradações.

CorFalsa - a que destoa do conjunto.

Cor Inexistente - é a cor complementar formada de entrechoques de tonalidade de uma cor levadas ao paroxismo por ação de contrastes (denominação de Israel Pedrosa). O elemento novo é a possibilidade de controlar tecnicamente o fenômeno e enquadrá-lo em bases práticas, de acordo com a distância em que se coloque o observador e os vários tons de cor observada, a qual deve também obedecer a padrões de forma pré-estabelecidos. O domínio do fenômeno da cor Inexistente possibilitou a revelação da essência da harmonia cromática, a sistematização dos dados que influem no surgimento das cores induzidas e as relações gerais que determinam as mutações cromáticas.

Colorido - diz-se da distribuição das cores na natureza. Efeito da aplicação de cor pigmento (ou cor tinta) sobre uma superfície.

CorDiótric a - a produzida pela dispersão da luz sobre os vários corpos refratores: prisma, lâminas delgadas, bolhas de sabão, manchas de óleo sobre água, etc.

CorCaptópic a - ou simplesmente cor, é a coloração revelada na superfície dos corpos opacos pela absorção e reflexão dos raios luminosos incidentes.

Cor Paróptric a - a que aparece na superfície dos corpos ocasionalmente, quase sempre de maneira fugaz, mas às vezes também, como existência mais duradora. É uma das formas das cores aparentes ou acidentais.

Cor Endóptric a - a que surge no interior de determinados corpos transparentes, a exemplo do efeito da calcita ótica Espato de Islândia, ligada a fenômenos de birrefrigência (refração da luz em dois raios polarizados ortogo- 
nais entre si).

\section{REERÊNCIAS BIBUOGRAFCAS}

REFERNTE AO TEXTO 2

CARDOSO, JOÃO DE DEUS. Quantida de e qualidade da cor no Ambiente Urbano. Dissertação de Mestrado, FAU USP, 1982.

CHEVREUL, MICHEL EUGÈNE; MARTEL, CHARLES. The principles of Ha mony and Contrast of Colours, and their a pplications to the arts. 3a. Ed. London: Henry G Bonn, 1839. (microforma/microfilme - http:// books.google.com.br acesso: fev 2011)

CHIJIWA, HIDEAKI. Color Ha rmony: a guide to creative color combinations. [Trad. Keiko Nakamura]. $1^{a}$. Ed. Cincinnati: Rockport Publishers, 1987.

CHUECA GOITIA, FERNANDO. Breve história do urbanismo. [Trad. Emílio Campos Lima]. 3ª. Ed. Lisboa: Editora Presença, 1982.

FARINA, MODESTO. Psicodinâmic a das Cores em Comunic ação. São Paulo: Edgard Blucher, 1989.

GOETHE, JOHANN WOLFGANG VON. Doutrina das Cores. [Trad. Marco Giannotti]. São Paulo: Nova Alexandria, 1993.

GOLDMAN, SIMÃO. Psic odinâmic a das Cores. 4ª. Ed. Caxias: Ed La Salle, 1964.

MARX, MURILLO DE AZEVEDO. Cidade Brasileira. São Paulo: Ed Melhoramentos : EDUSP, 1980.

MONZEGLIO, ÉLIDE. Cor. contribuição do estudo da cor e sua a plicação na programação de mensagens visuais. Tese de Doutoramento. FAU USP, 1972.

MONZEGLIO, ÉLIDE. Espaço / Cor. unidade de comunic ação. Tese de Livre Docência. FAU USP, 1979.

PEDROSA, ISRAEL. Da cor à cor inexistente. $3^{a}$. Ed. Brasília: Editora Universidade de Brasília [Rio de Janeiro] : Léo Christiano Editorial, 1982. 
"Existe numa tela de Corot (cujo título nao me ocorre de momento), uma paisagem quase monocromática onde, no meio de verdes sombrios se vê uma pequena figura vermelha. No entanto, essa pequena mancha é talvez a coisa mais vermelha que eu já vi"

(Gordon Cullen) 
